\title{
Arbeidsmarktmonitor metalektro 2002
}

Citation for published version (APA):

de Grip, A., van Loo, J. B., \& Sieben, I. J. P. (2003). Arbeidsmarktmonitor metalektro 2002.

Researchcentrum voor Onderwijs en Arbeidsmarkt, Faculteit der Economische Wetenschappen. ROA Reports No. 8 https://doi.org/10.26481/umarep.2003008

Document status and date:

Published: 01/01/2003

DOI:

10.26481/umarep.2003008

Document Version:

Publisher's PDF, also known as Version of record

\section{Please check the document version of this publication:}

- A submitted manuscript is the version of the article upon submission and before peer-review. There can be important differences between the submitted version and the official published version of record.

People interested in the research are advised to contact the author for the final version of the publication, or visit the DOI to the publisher's website.

- The final author version and the galley proof are versions of the publication after peer review.

- The final published version features the final layout of the paper including the volume, issue and page numbers.

Link to publication

\footnotetext{
General rights rights.

- You may freely distribute the URL identifying the publication in the public portal. please follow below link for the End User Agreement:

www.umlib.nl/taverne-license

Take down policy

If you believe that this document breaches copyright please contact us at:

repository@maastrichtuniversity.nl

providing details and we will investigate your claim.
}

Copyright and moral rights for the publications made accessible in the public portal are retained by the authors and/or other copyright owners and it is a condition of accessing publications that users recognise and abide by the legal requirements associated with these

- Users may download and print one copy of any publication from the public portal for the purpose of private study or research.

- You may not further distribute the material or use it for any profit-making activity or commercial gain

If the publication is distributed under the terms of Article $25 \mathrm{fa}$ of the Dutch Copyright Act, indicated by the "Taverne" license above, 


\title{
Arbeidsmarktmonitor Metalektro 2002
}

\author{
ROA-R-2003/8
}

Andries de Grip

Jasper van Loo

Inge Sieben

Researchcentrum voor Onderwijs en Arbeidsmarkt

Faculteit der Economische Wetenschappen en Bedrijfskunde Universiteit Maastricht

Maastricht, april 2003 
ISBN 90-5321-367-8

Sec03.038.doc 


\section{Inhoud}

Bladzijde

Voorwoord

Managementsamenvatting iii

Opzet van de monitor $\quad$ xvii

1 Kenmerken van de Metalektro $\quad 1$

1.1 Inleiding 1

1.2 Bedrijven in de Metalektro 1

1.3 Werknemers in de Metalektro 5

$\begin{array}{lll}1.4 & \text { Belangrijkste beroepen en opleidingen } & 7\end{array}$

2 Veranderingen in het personeelsbestand in $2002 \quad 9$

2.1 Inleiding 9

2.2 Gevolgen van veranderingen in de bedrijven 9

2.3 Instroom in de Metalektro 14

$\begin{array}{ll}2.4 & \text { Uitstroom in de Metalektro } \\ \end{array}$

3 Vacatures in de Metalektro 27

$\begin{array}{ll}3.1 & \text { Inleiding } \\ 3.2 & 27\end{array}$

3.2 Vacatures in de Metalektro 27

3.3 Problemen bij het vervullen van vacatures 32

3.4 Verwachte vacatures in $2003 \quad 34$

4 De verwachte arbeidsmarktontwikkeling in de Metalektro tot $2006 \quad 39$

$\begin{array}{ll}4.1 & \text { Inleiding } \\ 4.2 & 39\end{array}$

$\begin{array}{lll}4.2 & \text { Prognosemethodiek } & 39\end{array}$

4.3 De arbeidsmarkt voor de Metalektro tot $2006 \quad 41$

4.4 De mening van bedrijven over de prognoses 46

5 Omgaan met tekorten aan technisch personeel 49

$\begin{array}{ll}5.1 & \text { Inleiding } \\ 5.2 & 49\end{array}$

5.2 Werving en selectie 49

5.3 Interne aanpassingen 53

6 Competentieontwikkeling in de Metalektro $\quad 59$

6.1 Inleiding 59

6.2 Competenties van het technisch personeel 59

6.3 Veranderingen in competenties $\quad 62$

$\begin{array}{ll}6.4 & \text { Participatie in cursussen } \\ \end{array}$

7 HRM-beleid en employability $\quad 73$

$\begin{array}{ll}7.1 & \text { Inleiding } \\ 7.2 & 73\end{array}$

7.2 Algemeen beeld van het HRM-beleid in de Metalektro 73 
7.3 HRM-beleidsinstrumenten en employability

7.4 HRM-beleid en cursusdeelname

$\begin{array}{lll}\text { Bijlage A Het werkgeverspanel } & 79\end{array}$

$\begin{array}{lll}\text { Bijlage B } \quad \text { Classificaties } & 81\end{array}$ 


\section{Voorwoord}

De arbeidsmarkt in de Metalektro is sterk in ontwikkeling. Technologische ontwikkelingen, conjuncturele fluctuaties, verschuivingen in de vereiste competenties e.d. zorgen voor een grote dynamiek. Deze ontwikkelingen leiden vaak tot aanzienlijke knelpunten op de arbeidsmarkt, in de zin van een kwantitatieve en kwalitatieve slechte aansluiting tussen de vraag naar en het aanbod van arbeid. Om tot een structurele pro-actieve aanpak van de arbeidsmarktproblematiek in de Metalektro te komen, heeft de Stichting $\mathrm{A}+\mathrm{O}$ besloten een arbeidsmarktmonitor te ontwikkelen. Deze monitor moet inzicht geven in de actuele en toekomstige ontwikkelingen die van belang zijn voor de Metalektro, zowel op landelijk als op regionaal niveau. Met deze informatie zullen sociale partners en individuele bedrijven beter in staat zijn de verschillende aspecten van de personeelsproblematiek in de Metalektro aan te kunnen pakken.

Het Researchcentrum voor Onderwijs en Arbeidsmarkt (ROA) geeft invulling aan deze Arbeidsmarktmonitor Metalektro door landelijke arbeidsmarktinformatie te genereren en een werkgeverspanel op te zetten en te onderhouden. De gegevens uit deze twee bronnen staan in dit rapport centraal en geven een landelijk beeld van het werken in de Metalektro nu en in de toekomst. Daarnaast heeft Orbis Arbeid en Sociale Zekerheid BV in nauw overleg met de zes gevormde regioteams verkenningen uitgevoerd, waarbij de regionale aspecten van de Metalektro centraal staan. De uitkomsten van de metingen van het werkgeverspanel worden elk kwartaal gepubliceerd in een door de Stichting $A+O$ uitgegeven nieuwsbrief. Daarnaast ontvangen de bedrijven die deelnemen aan het werkgeverspanel bij iedere meting een "bedrijfsfoto". In dit benchmarkinstrument wordt de positie van het eigen bedrijf vergeleken met het algemene beeld van de bedrijfstak.

Dit rapport vormt de afsluiting van de eerste jaarcyclus Arbeidsmarktmonitor Metalektro 2002 en presenteert de belangrijkste landelijke gegevens verzameld uit de landelijke arbeidsmarktinformatie en het werkgeverspanel. Behalve door de auteurs is er bij het ROA aan dit rapport meegewerkt door Bart Diephuis, Timo Huijgen en Robert de Vries. We willen graag de leden van de regiecommissie Metalektro bedanken voor hun constructieve commentaar tijdens het gehele proces: Erik Anschütz, Hilde ter Doest, Henry de Groot en Nol Verhulst (Stichting A+O), Rien Smit (FME-CWM), Michiel van Hasselt (FNV bondgenoten), Ivo Kuijpers en Quirien van Ojen (Orbis Arbeid en Sociale Zekerheid BV) en Maarten Brouwer (CentERdata). Het veldwerk voor het werkgeverspanel Metalektro werd gedaan door Maarten Brouwer, Hanneke Dam, Mariëlle Klerks en Martijn van de Locht van CentERdata. Elly Schotmans (FME-CWM) was behulpzaam bij het opzoeken van achtergrondgegevens van bedrijven. Ten slotte bedanken we Klaas Roskam (Draka), Bert Jacques (Siemens Nederland) en Jan Rozema (Polynorm NV) voor het testen van de vragenlijsten. 



\section{Managementsamenvatting}

Dit rapport vormt de afsluiting van de eerste jaarcyclus van de Arbeidsmarktmonitor Metalektro 2002. Het rapport presenteert de belangrijkste resultaten uit twee informatiebronnen: de beschikbare landelijke arbeidsmarktinformatie en het nieuw opgezette Werkgeverspanel Metalektro. De landelijke arbeidsmarktinformatie bestaat uit actuele gegevens over (en trends in) de personeelsopbouw van de verschillende bedrijfssectoren binnen de Metalektro en van de verwachte knelpunten in de personeelsvoorziening. Deze gegevens zijn afkomstig van het CBS, dat een wat ruimere definitie van de Metalektrosector hanteert. Hierdoor kan op een aantal gebieden een wat vertekend beeld ontstaan. In het Werkgeverspanel Metalektro beantwoordt een representatieve groep bedrijven uit de Metalektro ieder kwartaal via Internet - vragen over de in- en uitstroom van personeel en de openstaande vacatures. Daarnaast geven zij informatie over belangrijke veranderingen in hun bedrijf, werving en selectie, inzetbaarheid van personeel, scholing en het gevoerde HRM-beleid.

\section{Kenmerken van de Metalektro}

De meeste bedrijven in de Metalekto zijn actief in de sectoren Metaalproductie (30\%) en machine-industrie (27\%). Een derde van de bedrijven in de Metalektro heeft een personeelsbestand van tussen de 100 en 250 medewerkers. Eén op de vijf bedrijven heeft minder dan 50 werknemers, terwijl het aandeel grote bedrijven met meer dan 500 werknemers bijna $10 \%$ is. De helft van de bedrijven bevindt zich in de regio's West en Zuidoost.

Net als in andere bedrijfssectoren, is er in de Metalektro sprake van een toenemend gebruik van informatie en communicatietechnologie (ICT) in het productieproces. Deze veranderingen op technologisch vlak hebben ook hun weerslag op de organisatie van bedrijven. Hoewel deze veranderingen doorgaans positieve effecten zullen hebben voor het bedrijf, kunnen er in bepaalde gevallen ook problemen door ontstaan. Zo heeft bijvoorbeeld ongeveer een kwart van de bedrijven in de Metalektro problemen met de automatisering. Circa $40 \%$ van de bedrijven noemt de kosten van het personeel en de werving van geschikt personeel een belangrijk probleem. Ten slotte vormt de grote concurrentie binnen de branche een probleem voor bedrijven in de Metalektro. Opmerkelijk is echter dat ruim 40\% van de bedrijven aangeeft dat hun belangrijkste concurrent buiten Nederland te vinden is. Hevige concurrentie van bedrijven in de eigen regio komt slechts bij $10 \%$ van de bedrijven voor. Dit geeft aan dat regionale samenwerking tussen bedrijven in de Metalektro met betrekking tot het arbeidsmarktbeleid nauwelijks belemmerd hoeft te worden door de onderlinge concurrentie op hun afzetmarkten.

Het aandeel vrouwen dat werkzaam is in de Metalektro is met $14 \%$ laag te noemen. Alleen in de sector elektrotechniek is het aandeel vrouwen met $22 \%$ wat hoger. Verder blijkt dat de leeftijdsverdeling van werknemers in de Metalektrosector weinig afwijkt van de leeftijdsverdeling van de totale werkzame bevolking in Nederland. Het 
percentage allochtone werknemers in de Metalelektro wijkt met $6 \%$ wel af van het landelijk gemiddelde van $4 \%$. In de basismetaal en de metaalproducten werken relatief gezien de meeste allochtonen.

Voor de Metalektro als geheel valt op dat het werkgelegenheidsaandeel met een VMBO-opleiding beduidend hoger ligt dan het landelijk gemiddelde. De hogere opleidingsniveaus (HBO en WO) zijn daarentegen relatief gezien wat ondervertegenwoordigd. Verder valt op dat er in de Metalektro minder in deeltijd gewerkt wordt en dat het aandeel werkenden met een flexibele arbeidsrelatie lager is dan het landelijk gemiddelde.

Metaalarbeiders, monteurs en bankwerkers en lassers zijn verreweg de grootste beroepen binnen de Metalektro. Ongeveer een kwart van de werkgelegenheid heeft betrekking op niet-technische, administratieve of ondersteunende beroepen. De meest voorkomende opleidingsachtergronden voor werkenden in de Metalektro zijn Basisonderwijs, VMBO mechanische techniek en MBO werktuigbouw en mechanische techniek, elk met een aandeel van $10 \%$ of meer.

\section{Veranderingen in de bedrijven en gevolgen voor het personeelsbestand}

In het werkgeverspanel Metalektro is nagegaan in hoeverre bedrijven in de Metalektro in 2001 te maken hebben gehad met veranderingen in omzet, productlijn, technologie en organisatie en welke gevolgen deze veranderingen hebben gehad voor het personeelsbestand van deze bedrijven.

Gemiddeld haalden bedrijven in 2001 een omzet van 38,5 miljoen euro. In meer dan de helft van de bedrijven is de omzet tussen 2000 en 2001 gestegen; in bijna één op de vijf bedrijven zelfs in sterke mate. Veel bedrijven met een stijging van de omzet hebben hun personeelsbestand uitgebreid. In één op de tien bedrijven met een omzetstijging heeft een herschikking van functies plaatsgevonden, terwijl herplaatsing en omscholing van personeel bij deze bedrijven weinig voorkomt. $13 \%$ van de bedrijven meldt dat de omzet in 2001 gelijk is aan de omzet in 2000. In één op de drie bedrijven is de omzet echter gedaald, hetgeen vaak gepaard is gegaan met het inkrimpen van het personeelsbestand met of zonder gedwongen ontslagen.

Ruim een derde van de bedrijven meldt dat ze in 2001 nieuwe producten zijn gaan produceren, terwijl ongeveer één op de tien bedrijven producten uit het pakket verwijderd heeft. Grote bedrijven hebben vaker veranderingen in hun productlijn doorgevoerd dan de kleinere bedrijven. Bij ongeveer één op de drie bedrijven hebben deze veranderingen gevolgen voor het personeel gehad. Zo geeft een kwart van de bedrijven die nieuwe producten in hun pakket opgenomen hebben aan hun personeelsbestand uitgebreid te hebben. Slechts bij een beperkt aantal bedrijven vindt er als gevolg van het introduceren van nieuwe producten ook een herschikking van functies en om- en bijscholing van personeel plaats.

Bij $18 \%$ van de bedrijven in de Metalektro is een belangrijke technologische vernieuwing, zoals robotisering, automatisering of het inzetten van nieuwe machines 
en productielijnen, geïntroduceerd. Ook hier geldt weer dat de grotere bedrijven innovatiever zijn dan kleinere bedrijven. lets minder dan de helft van de bedrijven, die in 2001 een technologische vernieuwing introduceerde, geeft aan dat dit directe gevolgen voor hun personeelsbestand heeft gehad. Daarbij gaat het vooral om het om- en bijscholen van personeel.

Ten slotte geeft de helft van de bedrijven in de Metalektro aan dat er in 2001 belangrijke veranderingen in de organisatie hebben plaatsgevonden. Het gaat dan met name om interne reorganisaties $(28 \%)$, overname door andere bedrijven $(11 \%)$ of het zelf overnemen van andere bedrijven (7\%). Opmerkelijk is dat grote bedrijven niet vaker organisatorische veranderingen doorvoeren dan kleine bedrijven. Interne reorganisaties hebben meestal grote gevolgen voor het personeelsbestand, omdat ze gepaard gaan met een herschikking van functies, herplaatsing van personeel of een inkrimping van het personeelsbestand.

\section{Instroom in de Metalektro}

In totaal werden er bij bedrijven in de Metalektro in het eerste kwartaal van 2002 bijna 4.250 nieuwe werknemers aangenomen. In het tweede kwartaal daalde dit aantal naar iets minder dan 3.750, om vervolgens in het derde kwartaal weer te stijgen naar zo'n 4.700 nieuwe werknemers. In het vierde kwartaal van 2002 bedroeg de instroom 4.400 werknemers. De grootste groep nieuwkomers heeft betrekking op de uitvoerende technici, zoals monteurs, productiemedewerkers en metaalarbeiders. De personeelsinstroom in deze functies is vooral groot in het derde kwartaal van 2002. Een uitzondering hierop vormen de bedrijven in de machine-industrie, die in het derde kwartaal juist minder nieuwe technici aangenomen hebben. De instroom van werknemers in ondersteunende, administratieve of commerciële functies is eveneens aanzienlijk. Opvallend is wel dat de instroom in deze functies in het derde kwartaal van 2002 een stuk lager ligt dan in de rest van het jaar.

Het grootste deel van de technici die bedrijven in 2002 aangetrokken hebben, was daarvoor reeds elders in de Metalektro werkzaam. In de loop van 2002 is het aantal technici dat van het ene bedrijf naar het andere bedrijf overstapt echter wel gedaald. $30 \%$ tot $40 \%$ van de instroom is afkomstig van bedrijven buiten de Metalektro. Kennelijk heeft de Metalektro nog steeds een duidelijke wervingskracht op de arbeidsmarkt voor technisch personeel. De voorkeur van werkgevers ligt duidelijk bij nieuwe technische werknemers die over enige werkervaring beschikken. Toch nemen bedrijven ook een flink aantal schoolverlaters aan. Met name in het derde kwartaal van 2002 stromen veel schoolverlaters de Metalektro in.

\section{Uitstroom in de Metalektro}

In totaal vertrokken er in de Metalektro in het eerste kwartaal van 2002 zo'n 5.700 werknemers bij hun bedrijf. In het tweede kwartaal nam dit aantal toe tot 7.000 , om daarna weer te zakken naar 6.200 in het derde kwartaal en 5.900 in het vierde kwartaal van 2002. De grootste uitstroom doet zich voor bij de uitvoerende technici. De uitstroom uit deze functies is met name groot in het tweede en derde kwartaal van 
2002. Ook de uitstroom van werknemers in ondersteunende functies als secretaresses, receptionisten, boekhouders, inkoop-verkoop medewerkers en schoonmakers is aanzienlijk. Het is opmerkelijk dat het seizoenspatroon in het personeelsverloop bij deze functies duidelijk afwijkt van het seizoenspatroon in het verloop van het uitvoerend technisch personeel. Met name in het eerste en het vierde kwartaal van 2002 vertrekken er veel werknemers uit de ondersteunende functies.

De instroom van werknemers in de Metalektro blijt in alle kwartalen van 2002 duidelijk achter bij de uitstroom. Hierdoor neemt het aantal werkenden af. Met name in het tweede kwartaal is de daling van het aantal werkenden groot. Opvallend is dat de daling in het aantal werknemers zich in alle sectoren binnen de Metalektro voordoet. Een uitzondering is echter de sector metaalproducten: in deze sector neemt in het derde kwartaal het aantal werknemers met een uitvoerende technische functie toe.

De instroom en uitstroom cijfers laten zien dat er naast de 'netto' ontwikkeling van de werkgelegenheid sprake is van een grote dynamiek op de arbeidsmarkt. Ook hier springt het tweede kwartaal van 2002 eruit. In totaal stroomden er toen bijna 14.250 werknemers bij bedrijven in de Metalektro in of uit. Met name bij het ondersteunend personeel blijkt er een grote dynamiek op de arbeidsmarkt te zijn.

Ongeveer eenderde van het technisch personeel dat vertrekt blijkt vrijwillig ontslag te hebben aangevraagd. Meestal spelen hierbij motieven als de betere carrièreperspectieven elders, de lange reistijd naar het werk, een te laag salaris en de slechte werksfeer een rol. Bij één op de vijf vertrekkende technici loopt een tijdelijk contract af dat niet verlengd wordt. Ook gedwongen ontslagen komen regelmatig voor, al is het opvallend dat het percentage technische werknemers dat om deze reden uitstroomt in de loop van 2002 afgenomen is. Verder blijkt het aantal technici dat met (vervroegd) pensioen gaat juist toe te nemen. Dit geeft aan dat de vergrijzing van het personeelsbestand in de Metalektro toeneemt.

Wat dit betreft is het opmerkelijk dat iets meer dan de helft van de bedrijven verwacht dat minder dan $5 \%$ van hun technisch personeel binnen vijf jaar met (vervroegd) pensioen zal gaan. Bij één op de tien bedrijven speelt de vergrijzing een veel grotere rol, aangezien daar meer dan $11 \%$ van het technisch personeel met pensioen zal gaan. De vergrijzingsgolf lijkt overigens vooral de grote bedrijven te treffen. Eenderde van de bedrijven denkt dat in de montageberoepen verhoudingsgewijs de meeste werknemers binnen vijf jaar met (vervroegd) pensioen gaan. Dan volgen de bankwerkers, lassers, machinaal verspaners en plaatverwerkers.

Wanneer bedrijven er niet in slagen de gepensioneerde technische werknemers te vervangen, kunnen er problemen ontstaan. Bijna de helft van de bedrijven verwacht echter weinig of geen problemen. $27 \%$ van de bedrijven denkt problemen te krijgen die met de nodige inspanningen wel oplosbaar zijn. Ongeveer $6 \%$ van de bedrijven verwacht daarentegen dat de problemen met de vervanging van technische werknemers die met pensioen gaan de komende jaren onoplosbaar groot zullen zijn. Opvallend is dat de grote bedrijven, die over het algemeen een hoger personeels- 
verloop vanwege pensionering verwachten, geen grotere problemen met de vervanging van deze werknemers verwachten dan kleine bedrijven. Wel blijkt dat de bedrijven in de regio's Rijndelta en West, waar het verwachte personeelsverloop vanwege pensionering hoog is, de grootste problemen verwachten.

Bedrijven verwachten met name problemen bij de vervanging van machinaal verspaners, bankwerkers, en - zoals verwacht - werknemers in de montageberoepen. Hoewel het aantal elektromonteurs dat met pensioen gaat redelijk klein is, verwachten veel bedrijven dat deze moeilijk te vervangen zijn. Opmerkelijk is verder dat de problemen met de vervanging van lassers - toch ook een groep waarin veel vergrijzing te vinden is - naar verwachting zullen meevallen. De minste problemen worden verwacht rondom de vervanging van werknemers die werken in de pijpverwerkende beroepen.

\section{Vacatures in de Metalektro}

Het is opmerkelijk dat er ondanks de minder rooskleurige economische situatie nog heel wat vacatures in de Metalektro openstaan, zeker voor uitvoerende technici. In het eerste kwartaal van 2002 stonden ruim 4.500 vacatures in de Metalektro open. In het tweede kwartaal steeg dit aantal zelfs tot ruim 5.000. In het derde en vierde kwartaal van 2002 waren er echter beduidend minder vacatures: respectievelijk zo'n 3.200 en 3.450. Het gemiddelde aantal vacatures per bedrijf is in de laatste twee kwartalen van 2002 ook duidelijk lager dan in de eerste twee kwartalen: 2,7 tegenover 4 à 5 in de eerste helft van 2002. Opvallend hierbij is dat deze daling in het gemiddelde aantal vacatures met name geldt voor de ondersteunende functies. In tijden van economische teruggang worden er kennelijk vooral minder vacatures voor deze ondersteunende functies geplaatst.

In de eerste drie kwartalen van 2002 blijken bedrijven in de Metaalproductie en de machine-industrie in alle beroepscategorieën minder openstaande vacatures te hebben dan bedrijven in de overige sectoren binnen de Metalektro. Bedrijven in de Rijndelta hebben het hele jaar door meer vacatures openstaan voor uitvoerende en leidinggevende technische functies en voor managementfuncties dan de bedrijven in de rest van het land. Bedrijven met een hoge personeelsuitstroom kennen over het algemeen ook meer vacatures dan bedrijven met weinig vertrekkende werknemers. Dit geldt voor alle onderscheiden beroepscategorieën, met uitzondering van de uitvoerende technici. Over het algemeen kunnen we dus stellen dat bedrijven met een hoog personeelsverloop niet primair te maken hebben met een daling van de werkgelegenheid, maar dat zij er minder goed in slagen om werknemers aan hun bedrijf te binden.

In 2002 was er een grote behoefte aan uitvoerende technici op MBO niveau. Met name voor werknemers in de montageberoepen en elektromonteurs zijn er veel vacatures. De behoefte aan nieuw laag- en ongeschoold personeel daalt daarentegen. Dit lijkt erop te wijzen dat er in de Metalektro steeds minder vraag is naar laaggeschoolde arbeid. 
Het grootste deel van de vacatures in de Metalektro staat korter dan 3 maanden open. De rest van de openstaande vacatures is volgens de gangbare definitie als moeilijk vervulbaar te kwalificeren. Eén op de tien vacatures voor technisch personeel staat zelfs langer dan één jaar open. Het is opmerkelijk dat de kleinere bedrijven vaker met moeilijk vervulbare vacatures worden geconfronteerd dan grote bedrijven. Grote bedrijven mogen dan wel meer vacatures voor technisch personeel hebben, ze blijken ze wel sneller te kunnen opvullen.

Vacatures kunnen om twee redenen ontstaan. In de eerste plaats vloeien vacatures voort uit een groei van de werkgelegenheid in een bepaalde functiecategorie (de uitbreidingsvraag). In het eerste kwartaal van 2002 is dit bij $65 \%$ van de bedrijven in de Metalektro het geval. Daarnaast heeft $66 \%$ van de bedrijven te maken met een vervangingsvraag. Deze vacatures ontstaan doordat er personeel vertrokken is vanwege pensionering, arbeidsongeschiktheid, (tijdelijke of gedeeltelijke) terugtrekking van de arbeidsmarkt en personeelsverloop naar andere bedrijven of sectoren.

\section{Problemen bij het vervullen van vacatures}

Ongeveer eenvijfde van de bedrijven in de Metalektro geeft aan veel tot erg veel problemen te ondervinden bij het aantrekken van werknemers die men graag in dienst wil hebben. Daar staat tegenover dat één op de drie bedrijven (erg) weinig problemen heeft bij het vinden van technisch personeel, terwijl nog eens $27 \%$ van de bedrijven helemaal geen problemen ondervindt. Opmerkelijk genoeg zijn er op dit punt geen verschillen tussen grote en kleine bedrijven. Kennelijk ervaren veel kleine bedrijven het grotere aantal vacatures dat langer dan 3 maanden openstaat als een gegeven.

Bijna $80 \%$ van de bedrijven die problemen ondervinden bij het aantrekken van technisch personeel meent dat dit komt door het te kleine aanbod van technici met de juiste kwalificaties. Veel bedrijven noemen ook het ontoereikende aanbod van technici met voldoende werkervaring. Andere belangrijke problemen zijn de te hoge salariseisen en andere eisen van sollicitanten.

De meeste bedrijven in de Metalektro worden geconfronteerd met flinke gevolgen door het tekort aan technici. Driekwart van de bedrijven met problemen geeft aan dat door dit tekort de werkdruk in hun bedrijf in het eerste kwartaal van 2002 toegenomen is, terwijl $45 \%$ zegt dat er werk is blijven liggen en dat deadlines gemist zijn. Bij $18 \%$ van de bedrijven was er zelfs sprake van een verlies aan orders. Ten slotte geeft $37 \%$ aan dat dit geleid heeft tot hogere wervings- en opleidingskosten. Deze gevolgen beklemtonen de ernst van de personeelsproblematiek in de Metalektro.

De helft van de bedrijven verwacht dat het aantal vacatures in 2003 ongeveer op hetzelfde niveau blijft als in 2002. Eén op de vijf bedrijven verwacht zelfs een toename van het aantal vacatures, meestal vanwege een uitbreiding van de werkgelegenheid. Dit betekent dat er ondanks de huidige conjuncturele situatie nog steeds behoefte is aan nieuwe werknemers, met name aan uitvoerende technici. 
Daar staat echter tegenover dat $31 \%$ van de bedrijven een afname van het aantal vacatures verwacht. Opmerkelijk hierbij is dat er relatief vaak een daling van het aantal vacatures voor de ondersteunende functies en de managementfuncties verwacht wordt. Blijkbaar zijn bedrijven onder het huidige economisch gesternte er op gericht hun personeelsbestand vooral in deze 'overhead' beroepen te beperken.

Aan de bedrijven in de Metalektro is ook gevraagd aan te geven of ze verwachten dat de problemen die zij zullen ondervinden bij het vinden van voldoende en/of geschikt technisch personeel zullen toe- of afnemen. $23 \%$ van de bedrijven verwacht dat deze problemen in 2003 zullen toenemen. Meestal verwacht men dat dit het gevolg is van het geringe aantal gediplomeerde schoolverlaters uit de technische opleidingen of van het afnemen van de kwalificaties van het aanbod aan technici. Ongeveer eenderde van de bedrijven verwacht dat de problemen met het vinden van technici gelijk zullen blijven, terwijl $14 \%$ van de bedrijven denkt dat de problemen zullen afnemen en $13 \%$ helemaal geen problemen verwacht. Deze bedrijven menen dat het grotere aanbod aan technici de problemen in de personeelsvoorziening zal verminderen. Aangenomen mag worden dat deze bedrijven denken dat dit toenemende aanbod vooral betrekking heeft op technisch personeel dat bij andere bedrijven overtollig wordt.

De verwachte arbeidsmarktontwikkeling in de Metalektro tot 2006

De Metalektro krijgt naar verwachting in de periode 2001-2006 te maken met een negatieve werkgelegenheidsontwikkeling ter grootte van ruim 9.000 arbeidsplaatsen oftewel $4 \%$ van de werkgelegenheid. Daarmee wijkt de Metalektro af van het gemiddelde beeld voor de andere bedrijfssectoren, waarvoor in de meeste gevallen een werkgelegenheidsgroei verwacht wordt.

Wanneer gekeken wordt naar de ROA prognoses van de werkgelegenheidsontwikkeling in de verschillende beroepsgroepen, dan blijkt dat de krimp zich naar verwachting niet in alle beroepsgroepen zal voordoen. Zo zijn de werkgelegenheidsperspectieven voor productieplanners, commercieel medewerkers (HBO niveau) en boekhouders en secretaresses relatief gunstig. De negatieve groeiverwachting voor 2001-2006 voor de Metalektro als geheel blijkt vooral gevolgen te hebben voor assembleurs, elektromonteurs, metaalarbeiders en receptionisten en administratieve medewerkers. Voor het merendeel van de beroepen worden ondanks de stagnerende werkgelegenheidsontwikkeling op de middellange termijn grote knelpunten in de personeelsvoorziening verwacht. Deze knelpunten zullen zich volgens de prognoses van het ROA echter niet voordoen bij de metaalarbeiders en productiemedewerkers.

De knelpunten in de personeelsvoorziening doen zich vooral voor bij het personeel op MBO niveau en hoger. De verwachte krimp in de werkgelegenheid concentreert zich bij de lager opgeleiden. De uitbreidingsvraag is het hoogst voor mensen met een opleiding MBO motorvoertuigentechniek en HBO bedrijfskunde. De vervangingsvraag concentreert zicht echter ook bij de lagere opleidingsniveaus, wat verklaard kan worden door het hoge percentage oudere werknemers met een lagere opleiding. 
Een substantieel aandeel van de bedrijven in de Metalektro is van mening dat deze ROA-prognoses juist zijn. Zo onderschrijft ongeveer eenderde van de bedrijven de verwachte werkgelegenheidskrimp in de Metalektro. Grote bedrijven zijn het overigens vaker eens met de negatieve groeivoorspelling dan kleine en middelgrote bedrijven. Dit zou erop kunnen wijzen dat de werkgelegenheidskrimp zich vooral zal voordoen bij het grootbedrijf.

Ongeveer de helft van de bedrijven onderschrijft de verwachte grote knelpunten voor bankwerkers en lassers in 2006 , terwijl ruim $40 \%$ van de bedrijven zich kan vinden in de verwachte grote knelpunten voor monteurs in 2006 . Het valt wel op dat bedrijven in de metaalproductensector relatief vaak kleinere knelpunten verwachten. Ten slotte herkent ongeveer vier op tien bedrijven het beeld dat er in 2006 vrijwel geen knelpunten voor metaalarbeiders zullen zijn. Een ander aanzienlijk deel van de bedrijven verwacht echter voor 2006 wel knelpunten. Vooral bedrijven in de metaalproductenindustie en de kleinere bedrijven geven relatief vaak aan dat ze grotere knelpunten verwachten dan het ROA voorspelt.

\section{Omgaan met tekorten aan technisch personeel}

Bedrijven kunnen op verschillende manieren inspelen op de tekorten aan technisch personeel. Zo komt het aanpassen van het wervings- en selectiebeleid als reactie op de personeelstekorten in bedrijven in de Metalektro veelvuldig voor. Het inschakelen van uitzendbureaus of andere commerciële werving- en selectiebureaus is met $80 \%$ veruit de meest populaire maatregel die bedrijven toepassen om met moeilijk vervulbare vacatures voor technisch personeel om te gaan. Daarnaast geeft ruim de helft van de bedrijven aan wel eens mensen met minder ervaring aan te trekken om de moeilijk vervulbare vacatures op te vullen. In de metaalproductenindustrie worden bij vacatureproblemen relatief vaak lager en anders opgeleiden aangetrokken, terwijl in de machine-industrie relatief vaak mensen met minder ervaring aangetrokken worden. De middelgrote bedrijven trekken het vaakst lager opgeleiden aan om vacatures op te vullen. Vooral kleinere bedrijven gaan er bij een tekort aan technisch personeel vaak toe over om werknemers met minder ervaring aan te trekken. Ook het bieden van een hoger salaris of betere arbeidsvoorwaarden is een maatregel waartoe kleine bedrijven overgaan. Het inschakelen van het arbeidsbureau is daarentegen met name populair bij de grote bedrijven.

Veel bedrijven geven aan dat ze werven via een uitzendbureau het meest effectief vinden. Eén op vijf bedrijven vindt dat adverteren in een regionaal dagblad het beste werkt om personeel te werven. Eenderde van de Metalektobedrijven geeft aan dat ze bij de werving van personeel (zeer) veel concurrentie ondervinden van bedrijven in de regio. Daarentegen is er bij het aantrekken van technisch personeel weinig concurrentie van bedrijven buiten de regio. Ook de arbeidsmarktconcurrentie tussen Metalektrobedrijven en niet-Metalektrobedrijven in de regio is beperkt. Wanneer dit al plaatsvindt, dan ondervinden bedrijven in de Metalektro de meeste concurrentie van de sector kleinmetaal. Daarnaast geeft één op vijf bedrijven aan bij de werving van technisch personeel concurrentie te ondervinden van bedrijven uit de chemie en de transport- en communicatiesector. 
Ruim $70 \%$ van de bedrijven in de Metalektro geeft aan dat ze interne maatregelen treffen om met moeilijk vervulbare vacatures om te gaan. Het blijkt dat dit met name het geval is bij de middelgrote en grote bedrijven. Overwerk en het flexibel inzetten van het huidige personeel zijn de meest genoemde maatregelen: ongeveer $70 \%$ van de bedrijven in de Metalektro geeft aan deze maatregelen toe te passen. Het uitbesteden van werk aan binnenlandse bedrijven en het intern om- of bijscholen van het eigen personeel is ook een vaak toegepaste maatregel om de personeelsproblemen te verminderen. Daarbij is het om- en bijscholen van het zittende personeel en het verder automatiseren vooral in de sector metaalproducten een belangrijk middel om met moeilijk vervulbare vacatures om te gaan. Het uitbesteden van werk aan binnenlandse bedrijven is in zowel de metaalproducten als in de machine-industrie populair, terwijl er in de overige sectoren minder gebruik van gemaakt wordt. Dit geldt ook voor het beperken van de productie. Daarnaast blijken kleine bedrijven hun personeel minder vaak om te scholen als reactie op knelpunten in de personeelsvoorziening dan middelgrote of grote bedrijven. Het uitbesteden van werk aan binnenlandse bedrijven en het beperken van de productie komt daarentegen vooral voor bij de kleine bedrijven.

Overwerk geeft bedrijven de mogelijkheid om met hetzelfde aantal personeelsleden de productie te verhogen en kan daarom gezien worden als een alternatief voor het aannemen van nieuw personeel. In bijna tien procent van de bedrijven is er sprake van structureel overwerk. Overwerk komt het meeste voor in de machine-industrie. Daarnaast blijkt structureel overwerk vooral voor te komen bij de grote bedrijven. Bijna acht op tien bedrijven geeft aan dat de belangrijkste reden van overwerk het opvangen van tijdelijke schommelingen in de bedrijfsdrukte is.

Ook het inlenen van werknemers kan een tijdelijke oplossing zijn voor een tekort aan personeel. $35 \%$ van de bedrijven in de Metalektro heeft meer dan $5 \%$ van het personeel ingeleend. De belangrijkste reden voor het inzetten van ingeleend personeel is het opvangen van schommelingen in de bedrijfsdrukte. Sommige bedrijven geven daarnaast aan dat het inlenen van personeel goedkoper is dan het aanstellen van vaste werknemers.

Ook het aannemen van werknemers met een tijdelijk contract (bijvoorbeeld door gebruik te maken van een uitzendbureau) kan problemen bij een tekort aan technici verzachten. Bedrijven in de machine-industrie hebben gemiddeld genomen minder tijdelijke werknemers in dienst dan bedrijven in de andere sectoren. Het percentage werknemers met een tijdelijk contract is het hoogst bij de grote bedrijven. De belangrijkste reden voor het gebruik maken van tijdelijke contracten is het dat dit een proeftijd voor nieuw personeel mogelijk maakt. Een tweede aspect dat vaak genoemd wordt is dat tijdelijke contracten de schommelingen in de bedrijfsdrukte kunnen opvangen.

Ten slotte kan de mate waarin werknemers functioneel inzetbaar zijn ook bijdragen aan het oplossen van wervingsproblemen. Het biedt de mogelijkheid om met het zittende personeel een grotere waaier van taken uit te voeren. Bij de meeste bedrijven (ruim 70\%) verricht het personeel echter geen taken die niet tot de eigen 
functie behoren. Wanneer het personeel wel andere taken uitvoert dan gaat het meestal om taken uit functies van een gelijk niveau. De sector metaalproducten valt op doordat hier het aantal bedrijven dat aangeeft dat het personeel geen andere taken uitvoert het hoogst is. Daarnaast blijkt dat vooral in de grote bedrijven het personeel andere taken uitvoert.

\section{Competentieontwikkeling in de Metalektro}

Over het algemeen is het goed gesteld met het competentieniveau van het technisch personeel in de Metalektro. Een ruime meerderheid van de bedrijven geeft aan dat hun technische werknemers over voldoende tot uitstekende competenties beschikken. Vooral de vaktechnische vaardigheden springen er in dit opzicht uit. Slechts één op de tien bedrijven geeft aan dat hun technisch personeel bepaalde vaktechnische vaardigheden onvoldoende of matig beheerst. Competenties die wat vaker als onvoldoende of matig beoordeeld worden zijn de commerciële vaardigheden, communicatie, leidinggeven en het probleem oplossend vermogen van het technisch personeel.

Het is overduidelijk dat het erg moeilijk is om technisch personeel te werven dat aan alle competentie-eisen voldoet. Toch is ruim de helft van de bedrijven niet echt ontevreden; zij typeren de aansluiting tussen de gevraagde kennis en vaardigheden en de kennis en vaardigheden van nieuw aangenomen technisch personeel als redelijk goed. Daarentegen sluiten in $38 \%$ van de bedrijven de competenties van het nieuw aangestelde personeel slechts in beperkte mate aan bij de eisen die de functie stelt. De hiaten in de kennis en vaardigheden van nieuwkomers zullen hier aangevuld moeten worden door middel van scholing op de werkplek of door werknemers specifieke cursussen te laten volgen. Kleine bedrijven melden overigens veel vaker dan grote bedrijven dat de competenties van nieuwe technische werknemers niet aansluiten op de gevraagde competenties. Zoals reeds bleek uit het aantal moeilijk vervulbare vacatures, hebben kleinere bedrijven meer moeite met het werven van geschikt technisch personeel dan de grotere bedrijven.

Er is in 2002 duidelijk sprake geweest van een upgrading van de vaktechnische competenties van het technisch personeel in de Metalektro. Meer dan de helft van de bedrijven vindt dat het niveau van de vaktechnische vaardigheden van hun technisch personeel in 2002 toegenomen is ten opzichte van het niveau in 2001 . Bijna $40 \%$ is van mening dat het niveau van deze vaardigheden gelijk is gebleven, terwijl slechts $7 \%$ van de bedrijven vindt dat het niveau is afgenomen.

Naast veranderingen in het competentieniveau van het technisch personeel, kunnen er ook veranderingen zijn opgetreden in de competenties die vereist zijn voor het adequaat uitoefenen van het werk. Maar liefst $82 \%$ van de bedrijven in de Metalektro vindt dat het vereiste niveau van kennis en vaardigheden voor technische functies in de afgelopen jaren steeds hoger geworden is.

Het is met name belangrijker geworden dat het technisch personeel beschikt over voldoende probleemoplossend vermogen. Bedrijven in de machine-industrie geven 
echter beduidend minder vaak aan dat deze competentie belangrijker geworden is. Ook het belang van de vaktechnische vaardigheden en het werken met IT is toegenomen. Daarnaast zijn communicatieve vaardigheden, het werken in teamverband, maar ook het zelfstandig kunnen werken het afgelopen jaar steeds belangrijker geworden voor het technisch personeel in de Metalektro. Opvallend is verder dat in middelgrote bedrijven (tussen de 100 en 250 medewerkers) het leidinggeven belangrijker geworden is voor het goed functioneren van technische medewerkers. Er wordt dus al met al steeds meer gevraagd van de technici in de Metalektro.

Bedrijven noemen als de belangrijkste oorzaken van het belangrijker worden van bepaalde competenties voor het goed functioneren van het technisch personeel het leggen van meer verantwoordelijkheden op een lager niveau in de organisatie (74\%), de toenemende automatisering $(71 \%)$ en het steeds all-rounder worden van technische functies $(60 \%)$. Grote bedrijven noemen overwegend dezelfde oorzaken voor het belangrijker worden van competenties dan kleine bedrijven. Bedrijven in de metaalproductie noemen wat vaker het specialistischer worden van technische functies als oorzaak voor de upgrading van de kwalificatie-eisen.

Om op deze veranderingen in de vereiste kennis en vaardigheden in te spelen, staan bedrijven twee opties ter beschikking in de vorm van een 'make or buy' beslissing. In de eerste plaats kunnen bedrijven aan hun werknemers scholing aanbieden om hen van meer kennis en vaardigheden te voorzien. Dit wordt wel de trainingsoptie genoemd. Negen op de tien bedrijven blijkt het technisch personeel op de werkplek op te leiden, en driekwart biedt hen cursussen aan. Daarnaast kunnen bedrijven ook nieuw technisch personeel aannemen dat wel over de gevraagde competenties beschikt. Deze recruitment-optie wordt door $45 \%$ van de bedrijven gehanteerd. Opvallend is dat middelgrote bedrijven veel vaker kiezen voor het werven van nieuw, gekwalificeerd personeel dan de kleine en grote bedrijven. Bedrijven die metaalproducten maken spelen wat vaker op de veranderingen in door hun technisch personeel op de werkplek op te leiden. Als we kijken naar de regionale verschillen, dan blijkt dat bedrijven in de regio Rijndelta hun personeel vaker cursussen laten volgen dan in de rest van het land. Wellicht hangt dit samen met het feit dat bedrijven in de Rijndelta wat moeilijker aan technici kunnen komen en meer vacatures voor technisch personeel hebben openstaan. Dit maakt de recruitment-optie voor deze bedrijven minder aantrekkelijk.

\section{Scholing in de Metalektro}

Het aanbieden van cursussen aan het technisch personeel is dus wijd verspreid binnen de Metalektro. Ruim 44\% van de bedrijven vindt het voor een optimaal productieproces ook zeer noodzakelijk om het technisch personeel bij- of om te scholen. De behoefte aan om- of bijscholing is het grootst bij bedrijven waar het competentieniveau van het technisch personeel tekortschiet. Met name in bedrijven waar technici onvoldoende of matig scoren op de competenties 'werken in teamverband' en 'probleemoplossend vermogen' wordt om- of bijscholing zeer gewenst gevonden. 
Overigens geeft bijna driekwart van de bedrijven in de Metalektro aan dat ze bij deze bij- en omscholing ondersteuning nodig hebben, met name in de vorm van het beschikbaar zijn van goede externe opleidingen en didactische ondersteuning bij interne cursussen. De behoefte aan ondersteuning is niet afhankelijk van bedrijfsgrootte of sector. Wel blijken bedrijven in de regio Oost wat minder behoefte aan ondersteuning bij om- of bijscholing te hebben dan bedrijven in de rest van Nederland.

In iets meer dan driekwart van de bedrijven nemen technici aan cursussen deel die door het eigen bedrijf georganiseerd worden. Daarnaast volgt het technisch personeel in bijna negen op de tien bedrijven het technisch personeel externe cursussen. Dit betekent dat in 2002 ruim 27.000 technische werknemers in de Metalektro een interne cursus volgden, terwijl nog eens bijna 30.000 technici participeerden in een externe cursus. In de machine-industrie zijn er beduidend minder bedrijven waar technische werknemers cursussen volgen dan in de overige sectoren. Daarnaast is het zo dat met name de middelgrote en grote bedrijven hun technici aan externe cursussen laten deelnemen.

Cursussen op het gebied van vaktechnische vaardigheden zijn het meest populair. Daarnaast worden er veel IT-cursussen gevolgd. In het algemeen blijkt dat er meer cursussen extern dan intern gevolgd worden. Alleen bij cursussen op het gebied van 'werken in teamverband' en 'zelfstandig werken' is de verhouding andersom: hierbij wordt vaker aan interne cursussen deelgenomen. Het volgen van een bepaalde cursus komt vaker voor bij bedrijven die aangeven dat de competentie waar deze cursus zich op richt in 2002 belangrijker geworden is. De verschillen tussen de bedrijven zijn met name groot bij de interne cursussen. Dit wijst erop dat er vooral geïnvesteerd wordt in competenties die steeds belangrijker worden voor het goed functioneren van technische werknemers.

Ook al worden er door technische werknemers in de Metalektro heel wat cursussen gevolgd, toch komt tweederde van de bedrijven belemmerende factoren tegen wanneer het om de cursusparticipatie van het technisch personeel gaat. Vaak kan technisch personeel niet gemist worden voor cursussen, vinden de cursussen op een ongunstig moment plaats, of kosten ze teveel geld. Andere belemmeringen die genoemd worden zijn dat het technisch personeel niet geïnteresseerd is in het volgen van een cursus, dat cursussen niet in de regio aangeboden worden en dat de kwaliteit van de aangeboden cursussen te laag is. Bedrijven in het Zuiden van Nederland geven overigens wat vaker aan dat de gewenste cursussen niet beschikbaar zijn in hun regio.

Ten slotte valt op dat in bedrijven die met één of meer belemmerende factoren te maken hebben het technisch personeel evenveel aan interne of externe cursussen deelneemt als in bedrijven die geen belemmeringen kennen. Dit zou erop kunnen wijzen dat de belemmerende factoren (nog) niet zo zwaarwegend zijn dat ze ook daadwerkelijk gevolgen hebben voor de cursusparticipatie van technische werknemers in de Metalektro. Een andere mogelijkheid is dat juist de bedrijven die 
meer willen investeren in de upgrading van de competenties van hun technisch personeel met belemmerende factoren geconfronteerd worden.

\section{HRM-beleid en employability}

De toenemende aandacht voor het menselijk kapitaal als sleutelfactor in het productieproces uit zich in een groeiende belangstelling voor het Human Resource Management (HRM) en een grotere eigen verantwoordelijkheid voor de ontwikkeling en loopbaan van het personeel. Ruim $80 \%$ van de bedrijven in de Metalektro geeft aan dat het HRM-beleid deel uit maakt van het strategisch beleid. Daarnaast worden in bijna $70 \%$ van de bedrijven middellange termijn HRM-bedrijfsdoelen geformuleerd. Dit houdt in dat in het overgrote deel van de Metalektrobedrijven de waarde van het personeel voor de onderneming in de bedrijfsstrategie erkend wordt. Dit geldt overigens vaker voor grote bedrijven dan voor kleine bedrijven.

Om het HRM-beleid te structureren of verder uit te bouwen, wordt er vaak gebruik gemaakt van HRM-kwaliteitskeurmerken. Het merendeel van de bedrijven in de Metalektro heeft een kwaliteitskeurmerk verworven of is daar mee bezig. Het kenmerk dat het meest voorkomt is het algemene keurmerk ISO-2000. Certificering van het kwaliteitsbeleid van bedrijven komt het meest voor bij de middelgrote en grote bedrijven.

Bedrijven kunnen hun HRM-beleid op verschillende manieren vormgeven. Zo kan de nadruk liggen op het opleiden van het personeel door het aanbieden van cursussen. Andere bedrijven streven ernaar hun personeel op een meer informele wijze inzetbaar te houden door het stimuleren van functieroulatie of andere mechanismen die het ervaringsdomein van de werknemers vergroten. In de meeste Metalektrobedrijven worden er aan alle medewerkers opleidingsfaciliteiten aangeboden en met alle werknemers functioneringsgesprekken gevoerd. Ook hebben de meeste bedrijven een bedrijfsopleidingsplan (BOP), beoordelingsgesprekken en geregeld werkoverleg. Het is opmerkelijk dat er nogal wat bedrijven zijn die reeds werken met een competentie- of vaardighedenmatrix en scholingsgesprekken voeren met (een deel van) het personeel. Voor zover bedrijven werken met functieroulatie heeft dit meestal slechts betrekking op een beperkt deel van het personeel. Bedrijven in de metaalproductensector werken minder vaak met persoonlijke ontwikkelingsplannen (POPs) dan bedrijven in de andere sectoren van de Metalektro. Kleine bedrijven maken in het algemeen wat minder vaak gebruik van HRM-instrumenten dan grote bedrijven.

Het bieden van opleidingsfaciliteiten en het houden van functioneringsgesprekken en geregeld werkoverleg worden het vaakst genoemd als de belangrijkste HRMinstrumenten om de employability van het technisch personeel te stimuleren. Relatief veel bedrijven in de machine-industrie vinden de competentie- of vaardighedenmatrix één van de belangrijkste HRM-instrumenten. In dezelfde sector worden daarentegen scholingsgesprekken heel weinig als een belangrijk HRM-instrument gezien. Voor de meeste HRM-instrumenten geldt dat het belang groter is naarmate de bedrijfsgrootte toeneemt. 
Het HRM-beleid van bedrijven bestaat vaak uit combinaties van bepaalde, aan elkaar gerelateerde, HRM-instrumenten. Zo zijn opleidingsfaciliteiten vaak onderdeel van een HRM-beleid waarin ook bedrijfsopleidingsplannen en scholings- en beoordelingsgesprekken een plaats hebben. Twee andere HRM-instrumenten die geregeld in combinatie voorkomen zijn het opstellen van persoonlijke ontwikkelingsplannen en het hebben van een competentie-of vaardighedenmatrix. Verder komen functioneringsgesprekken, scholingsgesprekken en geregeld werkoverleg relatief vaak in combinatie voor.

Als we kijken naar de effecten van HRM-instrumenten op de participatie van werknemers in cursussen dan zien we dat het bieden van opleidingsfaciliteiten het gemiddeld aantal cursussen per medewerker doet stijgen. Functieroulatie heeft een negatief effect op de gemiddelde cursusparticipatie. Dit zou verklaard kunnen worden doordat sommige bedrijven functieroulatie als een substituut zien voor het leren door middel van cursussen. Daarnaast neemt de cursusdeelname van het technisch personeel toe wanneer het niveau van de voor het werk vereiste vaktechnische vaardigheden toeneemt. De uitkomsten tonen verder aan dat met name het bieden van opleidingsfaciliteiten een erg belangrijk instrument is om de cursusparticipatie onder het technisch personeel te bevorderen. 


\section{Opzet van de monitor}

In dit rapport wordt gebruik gemaakt van twee informatiebronnen: landelijke arbeidsmarktinformatie en het werkgeverspanel Metalektro. De landelijke arbeidsmarktinformatie wordt door het ROA in het kader van het Project Onderwijs-Arbeidsmarkt (POA) verzameld. Deze arbeidsmarktinformatie wordt bewerkt voor de Metalektrosector en bestaat uit twee onderdelen.

- De monitoring van ontwikkelingen op de arbeidsmarkt

Hierbij gaat het om actuele gegevens over (en trends in) de personeelsopbouw van de verschillende bedrijfssectoren in de Metalektro. Er wordt gekeken naar de samenstelling van het personeel naar geslacht, leeftijd, etniciteit, regio, deeltijdwerk, opleidingsniveau, opleidingsrichting en beroepsgroep. Hierbij wordt met name gebruik gemaakt worden van informatie die beschikbaar is bij het CBS, zoals de Enquête Beroepsbevolking (EBB).

- Arbeidsmarktprognoses voor de middellange termijn (tot 2006)

De middellange termijn prognoses hebben betrekking op de verwachte knelpunten in de personeelsvoorziening. Deze prognoses zijn gebaseerd op onder meer de Enquête Beroepsbevolking (EBB) van het $\mathrm{CBS}$ en de referentieramingen van leerlingen in het onderwijssysteem van het Ministerie van OCenW.

Zoals bekend is de beschikbare landelijke arbeidsmarktinformatie vaak niet goed herkenbaar en bruikbaar in de sector zelf. Daarom is er een nieuwe informatiebron opgezet in de vorm van het Werkgeverspanel Metalektro. Dit werkgeverspanel bestaat uit een representatieve groep bedrijven uit de Metalektro. Meer informatie over de respons en representativiteit van het panel is te vinden in bijlage $A$.

Bij de deelnemende bedrijven vult de contactpersoon ieder kwartaal - via Internet een vragenlijst in. Deze vragenlijst bevat ongeveer 20 vragen. Een deel hiervan komt ieder kwartaal terug, waardoor betrouwbare informatie verkregen wordt over de inen uitstroom van personeel en de openstaande vacatures. Daarnaast kent iedere vragenlijst een thema: werving en selectie, inzetbaarheid van personeel, scholing en HRM-beleid. Tabel 0.1 geeft een overzicht van de vier metingen van het werkgeverspanel Metalektro in 2002. Hieruit blijkt dat meer dan 200 bedrijven een vragenlijst hebben ingevuld bij de eerste twee metingen. De respons bedroeg maar liefst $63 \%$. Daarna liep het aantal terug tot 180 bedrijven bij meting 3 en 155 bij meting 4 . Een dergelijke uitval van respondenten is niet ongebruikelijk bij panelonderzoek, maar noodzaakt wel tot aanvulling van het panel in 2003.

Naast de vier vragenlijsten, is er in november 2002 ook een vragenlijst voorgelegd aan een tweede contactpersoon binnen het bedrijf, namelijk een lid van het management of directie. In deze managementmeting werden vragen gesteld over belangrijke veranderingen in het bedrijf en de gevolgen hiervan voor het personeelsbestand. 
Tabel 0.1

Overzicht van de metingen van het werkgeverspanel Metalektro 2002

\begin{tabular}{llll}
\hline Meting & Veldwerk & Thema & Aantal bedrijven \\
& & Werving en selectie & 217 \\
1 & Maart - april 2002 & Inzetbaarheid van personeel & 218 \\
2 & Juni - juli 2002 & Scholing & 180 \\
3 & September - oktober 2002 & 155 \\
4 & December 2002 - januari 2003 & HRM-beleid & \\
\hline
\end{tabular}

Bron: ROA/Werkgeverspanel Metalektro 2002

Tevens werd een reactie gevraagd op de middellange termijnprognoses die door het ROA zijn opgesteld. Voor deze meting werden naast de aan het werkgeverspanel deelnemende bedrijven opnieuw weer alle overige bedrijven in de Metalektro benaderd. Van de 197 bedrijven die aangaven mee te willen doen hebben uiteindelijk 110 de vragenlijst van de managementmeting ingevuld (een respons van $56 \%$ ).

\section{Opzet van dit rapport}

De opzet van dit rapport is als volgt. In hoofdstuk 1 wordt ingegaan op enkele belangrijke kenmerken van de sector. Zo wordt er gekeken naar bedrijfsgrootte, bedrijfssector en regio en naar de problemen die bedrijven in de Metalektro ervaren. Ook komt de samenstelling van het personeelsbestand in de Metalektro aan bod, verbijzonderd naar geslacht, leeftijd, opleidingsniveau en het soort dienstverband. Ten slotte wordt aangegeven welke beroepen en opleidingen veel voorkomen in de sector.

In hoofdstuk 2 komen de veranderingen in het personeelsbestand in 2002 aan bod. Allereerst wordt nagegaan in hoeverre bedrijven in de Metalektro met een verandering in omzet, productlijn, technologie en organisatie te maken hebben gehad en welke gevolgen deze veranderingen hadden voor het personeelsbestand van deze bedrijven. Daarna wordt de ontwikkeling van de instroom van nieuwe werknemers in de Metalektro in 2002 in kaart gebracht, en wordt de herkomst van deze instroom nagegaan. Hoofdstuk 2 sluit af met het in kaart brengen van de ontwikkeling in de personeelsuitstroom in de Metalektro, de dynamiek in de sector, en de reden van vertrek. Hierbij wordt ook nader ingegaan op het probleem van de vergrijzing.

Hoofdstuk 3 gaat in op de ontwikkeling van de vacatureproblematiek in de Metalektro in 2002. Er wordt beschreven hoeveel vacatures er per kwartaal openstaan, in welke functies ze zich voordoen, hoe lang ze openstaan en om welke reden ze ontstaan zijn. Vervolgens wordt aandacht besteed aan de problemen die bedrijven in de Metalektro ondervinden bij het vervullen van vacatures voor technici en de gevolgen van deze problemen. Ten slotte wordt antwoord gegeven op de vraag welke verwachtingen de bedrijven in de Metalektro hebben met betrekking tot de ontwikkeling van de vacatureproblematiek in 2003. 
In hoofdstuk 4 worden de verwachte arbeidsmarktontwikkelingen in de Metalektro voor de middellange termijn gepresenteerd. Deze voorspellingen tot 2006 worden per sector, beroep en opleiding beschreven. Ook wordt nagegaan in hoeverre de bedrijven in de Metalektro deze prognoses onderschrijven.

Hoofdstuk 5 gaat in op de vraag hoe bedrijven in de Metalektro omgaan met tekorten aan technisch personeel. Allereerst komen de aanpassingen die bedrijven in hun werving en selectie treffen om de tekorten aan technisch personeel op te lossen aan bod. Daarbij zal ook aandacht besteed worden aan de effectiviteit van de verschillende wervingskanalen en de concurrentie die bedrijven in de Metalektro op de arbeidsmarkt ondervinden van bedrijven uit de eigen sector en van bedrijven uit andere sectoren. Daarna wordt ingegaan op de interne aanpassingen die bedrijven treffen om met hun personeelstekorten om te gaan. Het gaat dan om instrumenten als overwerk, het 'inlenen' van werknemers en het functioneel flexibel inzetten van het personeel.

In hoofdstuk 6 wordt aandacht besteed aan competentieontwikkeling en scholing in de Metalektro. Allereerst worden de competenties van het technisch personeel in kaart gebracht. Hierbij wordt ook ingegaan op veranderingen in het competentieniveau en op veranderingen in het belang van bepaalde competenties voor het goed functioneren van het technisch personeel. Hoofdstuk 6 sluit af met een beschrijving van de participatie van werknemers in interne en externe cursussen. Er wordt onderzocht welke cursussen in de Metalektro het meest gevolgd worden en welke belemmeringen bedrijven ondervinden bij de cursusparticipatie van hun werknemers.

Ten slotte staat in hoofdstuk 7 het HRM-beleid van de bedrijven in de Metalektro in relatie met de employability van werknemers centraal. Eerst wordt er een algemene beschrijving gegeven van het HRM-beleid van de bedrijven in de Metalektro. Ook wordt er ingegaan op de HRM-kwaliteitskeurmerken die de bedrijven in de Metalektro hebben. Daarna wordt aandacht besteed aan de HRM-instrumenten die bedrijven in de Metalektro gebruiken. Als laatste komt de relatie tussen het HRM-beleid en de mate waarin werknemers aan cursussen deelnemen aan de orde.

Achter in dit rapport zijn twee bijlages te vinden. Bijlage A gaat in op de opzet en de uitvoering van het werkgeverspanel Metalektro. Bijlage B geeft een overzicht van de in dit rapport gebruikte classificaties. 



\section{Kenmerken van de Metalektro}

\section{$1.1 \quad$ Inleiding}

In dit hoofdstuk wordt een overzicht gegeven van de kenmerken van zowel de bedrijven als de werkenden in de sector Metalektro. Het hoofdstuk heeft als doel om een algemeen beeld te schetsen van de sector. Waar mogelijk zal ook aandacht besteed worden aan verschillen tussen bedrijfssectoren binnen de Metalektro en tussen bedrijven van verschillende grootte.

Eerst wordt in paragraaf 1.2 ingegaan op enkele kenmerken van de bedrijven in de Metalektro en de problemen die zij ervaren. Daarbij wordt eerst gekeken naar de bedrijfsgrootte, de verdeling naar bedrijfssector en de regionale spreiding. Daarna komen de problemen die Metalektrobedrijven ervaren aan bod. Vervolgens worden in paragraaf 1.3 de kenmerken van de werkenden in beeld gebracht. Hierbij zal worden ingegaan op persoonskenmerken (geslacht, leeftijd, opleidingsniveau, etc.) van werkenden en het soort dienstverband dat zij hebben (vast of tijdelijk, deeltijd of voltijd, etc.). In paragraaf 1.4 wordt bekeken welke beroepen veel voorkomen in de sector en zal ingegaan worden op de opleidingsachtergrond van de werkenden in de Metalektro.

\subsection{Bedrijven in de Metalektro}

De Metalektro is een sector waarin bedrijven met nogal uiteenlopende werknemersaantallen voorkomen. Zo zijn er bijvoorbeeld bedrijven met minder dan 10 werknemers, maar ook bedrijven met meer dan 5.000 medewerkers. In deze paragraaf wordt de structuur van de Metalektro in beeld gebracht waarbij gebruik gemaakt wordt van de gegevens van de ruim 350 Metalektro-bedrijven die één keer of vaker aan het werknemerspanel Metalektro hebben deelgenomen.

\section{Bedrijfssector}

In tabel 1.1 wordt de verdeling van bedrijven in de Metalektro naar bedrijfssector (zie ook bijlage B voor de gebruikte classificaties) gepresenteerd. De meeste bedrijven in de Metalektro behoren tot de sector metaalproducten of de machine-industrie.

Tabel 1.1

Bedrijven naar bedrijfssector

Bedrijfssector

Basismetaal

Metaalproducten

Machine-industrie

Elektrotechniek

Transportmiddelen

Overig 
Het aandeel bedrijven in de elektrotechniek en de transportmiddelensector is wat lager. Het aandeel van de basismetaal is het laagst.

\section{Bedrijfsgrootte}

Tabel 1.2 geeft een overzicht van de omvang van de bedrijven in de Metalektro op basis van het aantal werkenden. De meeste bedrijven in de Metalektro (32\%) hebben een personeelsbestand van tussen de 100 en 250 medewerkers. Een kwart van de bedrijven heeft meer dan 50 maar minder dan 100 medewerkers. Ook zijn er relatief veel kleine bedrijven: één op de vijf bedrijven heeft een personeelsbestand kleiner dan 50 werknemers. Daarentegen heeft minder dan één op de tien bedrijven meer dan 500 werknemers in dienst.

Tabel 1.2

Bedrijven naar bedrijfsgrootte

\begin{tabular}{lr}
\hline Bedrijfsgrootte & $\%$ \\
\hline Tot 50 medewerkers & 20 \\
$50-100$ medewerkers & 26 \\
$100-250$ medewerkers & 32 \\
$250-500$ medewerkers & 13 \\
500 of meer medewerkers & 9
\end{tabular}

Bron: ROA/Werkgeverspanel Metalektro 2002

\section{Regionale spreiding}

Tabel 1.3 geeft een overzicht van de regionale spreiding van de bedrijven in de Metalektrosector. De helft van de bedrijven bevindt zich in de regio Zuidoost of West. Ongeveer één op vijf bedrijven behoort tot de regio Oost. De regio's Zuidwest, Rijndelta en Noord hebben elk een aandeel van rond de $10 \%$. Overigens verschilt de verdeling van bedrijven naar bedrijfssector per regio. Zo is het aandeel van bedrijven in de basismetaal in de regio Zuidwest relatief hoog (13\%), terwijl deze bedrijfssector met $5 \%$ in de regio Oost wat ondervertegenwoordigd is. Voor de metaalproductensector is het aandeel in de regio Rijndelta relatief laag $(20 \%)$ in vergelijking met de andere regio's. De machine-industrie vormt een relatief groot deel van de Metalektrosector in de regio Oost (38\%). Bedrijven in de elektrotechniek zijn wat oververtegenwoordigd in de regio's Zuidoost en Noord (beide 18\%). Het aandeel van bedrijven in de sector transportmiddelen is tenslotte relatief hoog in de Rijndelta $(22 \%)$.

Ook de bedrijfsgrootte lijkt samen te hangen met de regio waar bedrijven gevestigd zijn. Zo heeft de regio Noord het hoogste aandeel kleine bedrijven, terwijl middelgrote en grote bedrijven relatief weinig voorkomen. In de Rijndelta komen relatief vaak bedrijven voor met 250 medewerkers of meer. In de regio's Zuid-Oost en Zuid-West overheersen de middelgrote bedrijven met 100-250 medewerkers. 
Tabel 1.3

Bedrijven naar regio

\begin{tabular}{lr}
\hline Regio & $\%$ \\
\hline Zuidwest & 10 \\
Zuidoost & 24 \\
Rijndelta & 12 \\
West & 25 \\
Oost & 19 \\
Noord & 11
\end{tabular}

Bron: ROA/Werkgeverspanel Metalektro 2002

\section{Veranderingen en problemen in de Metalektro}

Net als vele andere bedrijfssectoren in de Nederlandse economie is er in de Metalektrosector de laatste jaren sprake geweest van ingrijpende ontwikkelingen. Een in het oog springende ontwikkeling is het toenemend gebruik van informatie- en communicatietechnologie in het productieproces. Wat betreft het investeren in ICT loopt de Metalektro voorop: tussen 1997 en 2001 groeiden de reële automatiseringskosten met maar liefst $17 \%$ per jaar. Ter vergelijking: in de chemie bedroeg dit percentage $6 \%$ en in de sector transport en communicatie stegen de reële automatiseringskosten met $10 \%{ }^{1}$ Hoewel het gemiddeld aantal pc's per bedrijf niet spectaculair groeide in die periode, zijn de mogelijkheden ervan wel uitgebreid: het gemiddeld aantal pc's met een aansluiting op het Internet groeide immers met ruim $25 \%$.

De veranderingen op technologisch vlak hebben vaak tot gevolg dat ook de organisatie van bedrijven gewijzigd wordt. In hoofdstuk 2 zal hier uitgebreid op worden ingegaan, waarbij tevens zal worden aangegeven in hoeverre deze ontwikkelingen leiden tot veranderingen in het personeelsbestand.

Veranderingen kunnen ertoe leiden dat bepaalde bedrijven geconfronteerd worden met problemen. In tabel 1.4 wordt een overzicht gegeven van de belangrijkste problemen die bedrijven in de Metalektro in 2001 ervaren hebben. Het meest genoemde probleem vormt de concurrentie van andere bedrijven binnen de Metalektro. Ruim 40\% van de bedrijven noemt ook de kosten van het personeel en de werving van geschikt personeel als belangrijk probleem. Met de automatisering heeft ongeveer een kwart van de bedrijven in de Metalektro problemen. $21 \%$ van de bedrijven heeft te kampen met omzetproblemen. De overige genoemde problemen in tabel 1.4 zijn voor een minderheid van de ondervraagde bedrijven van belang.

Omdat de concurrentie van bedrijven uit de eigen branche het meest genoemd wordt als belangrijk probleem, kijken we in figuur 1.1 waar die concurrentie vooral vandaan komt. Het internationale karakter van de Metalektro wordt onderstreept door het feit dat ruim $40 \%$ van de bedrijven aangeeft dat hun belangrijkste concurrent in de Europese Unie (maar buiten Nederland) gevestigd is. Eenderde van de bedrijven

1. Zie ROA (2002), Werkgelegenheid en Scholing, ROA-R-2002/7, Maastricht. 
geeft aan dat hun belangrijkste concurrent zich in Nederland bevindt, maar niet in de eigen regio. Het aandeel van bedrijven dat vindt dat hun belangrijkste concurrent in de eigen regio actief is, is met $10 \%$ een stuk lager. Dit geeft aan dat regionale samenwerking tussen bedrijven in de Metalektro met betrekking tot het arbeidsmarktbeleid nauwelijks belemmerd wordt door de onderlinge concurrentie op hun afzetmarkten.

Tabel 1.4

Belangrijke problemen voor bedrijven in de Metalektro in 2001*

Probleem

Concurrentie binnen de branche

Kosten van personeel

Werving van geschikt personeel

Automatisering

Omzet

Kwaliteitszorg

Interne communicatie

Financiering

Logistiek

Arbozaken

(EU)wetgeving

Kosten van huisvesting

Milieuaangelegenheden

Concurrentie buiten de branche

* De verschillende percentages staan los van elkaar en hoeven dus niet op te tellen tot

Bron: ROA/Werkgeverspanel Metalektro 2002

\section{Figuur 1.1}

Vestigingsplaats van de belangrijkste concurrent

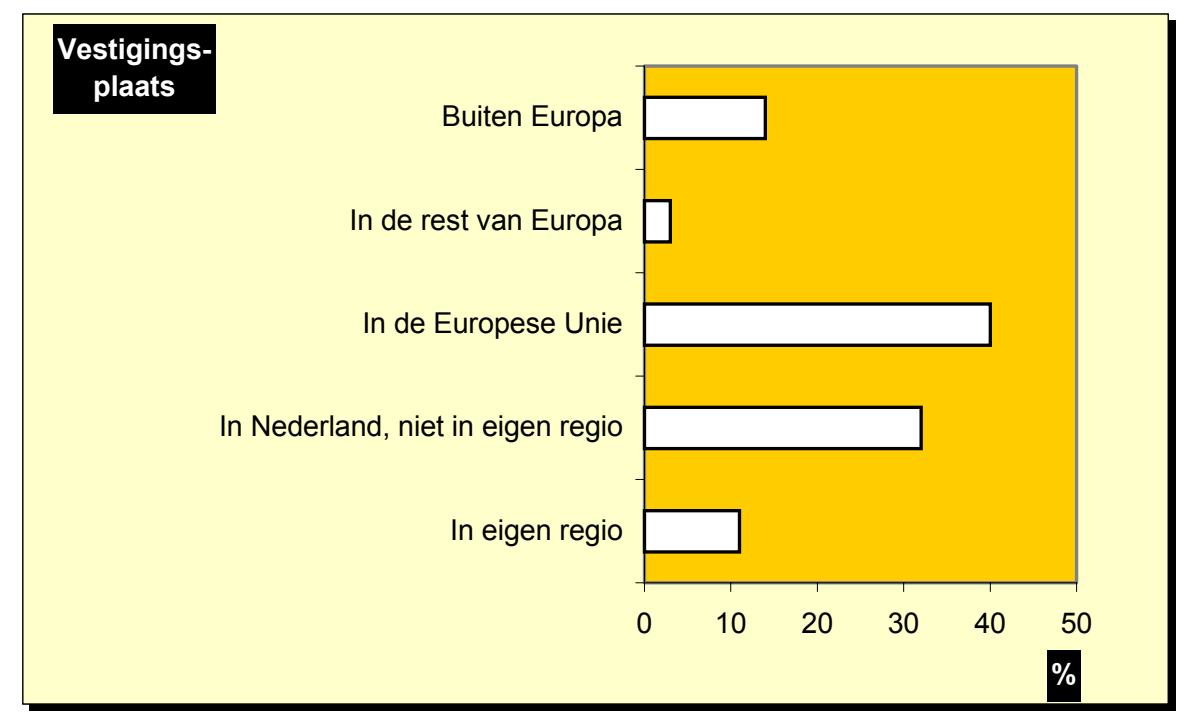

Bron: ROA/Werkgeverspanel Metalektro 2002 


\subsection{Werknemers in de Metalektro}

Tabel 1.5 geeft allereerst een overzicht van de belangrijkste persoonskenmerken van de werkenden in de Metalektrosector. Deze cijfers zijn afkomstig van het CBS, dat een wat bredere definitie van de Metalektrosector hanteert (zie ook de classificaties in bijlage B). Zo valt volgens het CBS bijvoorbeeld ook de kleinmetaal onder de Metalektro. Deze afwijkende definitie kan op een aantal gebieden een wat vertekend beeld geven.

Het aandeel vrouwen in het personeelsbestand van de Metalektro is met $14 \%$ relatief laag in vergelijking met het aandeel werkende vrouwen in de gehele Nederlandse economie, dat rond de $40 \%$ ligt. In de sector elektrotechniek is het aandeel vrouwen in de werkgelegenheid overigens duidelijk hoger dan in de andere sectoren binnen de Metalektro.

De leeftijdsopbouw van de werkenden in de Metalektrosector wijkt weinig af van de leeftijdsopbouw van de totale werkzame Nederlandse beroepsbevolking. Ongeveer een kwart van de werkenden is jonger dan 30 jaar, terwijl circa $20 \%$ tot de oudere werknemers gerekend mag worden.

Het percentage allochtonen onder de werkenden in de Metalektro ligt met $6 \%$ wel duidelijk boven het landelijk gemiddelde van $4 \%$. In de basismetaal en de metaalproducten werken relatief gezien de meeste allochtonen.

Tabel 1.5

Persoonskenmerken van werkenden in de Metalektro, naar bedrijfssector, gemiddelde 19992000

\begin{tabular}{|c|c|c|c|c|c|c|}
\hline Kenmerk & $\begin{array}{l}\text { Basis- } \\
\text { metaal }\end{array}$ & $\begin{array}{l}\text { Metaal- } \\
\text { producten }\end{array}$ & $\begin{array}{l}\text { Machine- } \\
\text { industrie }\end{array}$ & $\begin{array}{l}\text { Elektro- } \\
\text { techniek }\end{array}$ & $\begin{array}{l}\text { Transport- } \\
\text { middelen }\end{array}$ & Metalektro \\
\hline \multicolumn{7}{|l|}{ Geslacht: } \\
\hline - Vrouw & - & 11 & 11 & 22 & 10 & 14 \\
\hline - Man & - & 89 & 89 & 78 & 90 & 86 \\
\hline \multicolumn{7}{|l|}{ Leeftijd: } \\
\hline - Jong (15-29) & 17 & 27 & 23 & 23 & 25 & 24 \\
\hline - Middel (30-49) & 64 & 56 & 54 & 59 & 55 & 57 \\
\hline - Oud (50-64) & 19 & 17 & 23 & 18 & 20 & 19 \\
\hline \multicolumn{7}{|l|}{ Etniciteit: } \\
\hline - Allochtoon* & 12 & 7 & 4 & 5 & 6 & 6 \\
\hline - Autochtoon & 88 & 93 & 96 & 95 & 94 & 94 \\
\hline
\end{tabular}

* 'Allochtoon' heeft betrekking op iedereen die een niet-Nederlandse nationaliteit bezit, of die buiten Nederland is geboren, in één van de landen die genoemd worden in de Wet Bevordering Evenredige Arbeidsdeelname Allochtonen (WBEAA).

- Duidt op een percentage dat betrekking heeft op een aantal beneden door het CBS gestelde publicatiegrenzen.

Bron: CBS/Enquête Beroepsbevolking (EBB) 1999 en 2000 


\section{Opleidingsniveau}

Tabel 1.6 geeft een overzicht van de opleidingsachtergronden van de werkenden in de Metalektro. Het aandeel van werkenden met een VMBO-opleiding ligt met $28 \%$ beduidend hoger dan het landelijk gemiddelde van $20 \%$. Daarentegen werken er in de Metalektro relatief minder hoog opgeleiden. 18\% van de werkenden heeft een $\mathrm{HBO}$ of universitaire opleiding, tegenover $28 \%$ van de totale werkzame beroepsbevolking in Nederland. Voor de sector elektrotechniek geldt dit overigens niet. In deze sector is het aandeel hoog opgeleiden meer dan 30\%, wat waarschijnlijk te maken heeft met feit dat in deze sector de functies in het algemeen wat complexer zijn.

Tabel 1.6

Opleidingsniveau werkenden in de Metalektro, naar bedrijfssector, gemiddelde 1999-2000

\begin{tabular}{lcccccr}
\hline Opleidingsniveau & $\begin{array}{c}\text { Basis- } \\
\text { metaal }\end{array}$ & $\begin{array}{c}\text { Metaal- } \\
\text { producten }\end{array}$ & $\begin{array}{c}\text { Machine- } \\
\text { industrie }\end{array}$ & $\begin{array}{c}\text { Elektro- } \\
\text { techniek }\end{array}$ & $\begin{array}{c}\text { Transport- } \\
\text { middelen }\end{array}$ & Metalektro \\
\hline Basisonderwijs & 14 & 12 & 6 & 7 & 11 & 9 \\
VMBO & 26 & 34 & 25 & 22 & 30 & 28 \\
MBO & 43 & 44 & 51 & 41 & 44 & 45 \\
HBO & 14 & 9 & 14 & 22 & 11 & 14 \\
WO & - & - & 3 & 9 & - & 4 \\
Totaal & 100 & 100 & 100 & 100 & 100 & 100
\end{tabular}

- Duidt op een percentage dat betrekking heeft op een aantal beneden door het CBS gestelde publicatiegrenzen.

Bron: CBS/Enquête Beroepsbevolking (EBB) 1999 en 2000

\section{Functiekenmerken}

In tabel 1.7 wordt een overzicht gegeven van enkele kenmerken van de dienstverbanden in de Metalektrosector. Slechts een beperkt deel van het personeel (9\%) is werkzaam in deeltijd. ${ }^{2}$ Dit verschilt sterk met het landelijke cijfer van $30 \%$, en heeft waarschijnlijk ook te maken met het lage aandeel van vrouwelijke werknemers in de sector. Het relatief geringe aantal deeltijdwerkers weerspiegelt zich in het gemiddeld aantal uren dat er in de metalektrosector wekelijks gewerkt wordt: 39 uur.

Het aandeel van werkenden met een flexibele arbeidsrelatie ligt met $7 \%$ dichter bij het landelijk gemiddelde van $9 \%$. Van de onderliggende sectoren valt alleen de elektrotechniek op, aangezien het aandeel flexibel werkenden hier $9 \%$ bedraagt. Naast de werkenden met een flexibele aanstelling binnen de Metalektro kunnen de bedrijven ook gebruik maken van personeel dat wordt ingehuurd op detacheringbasis. Deze laatste groep wordt met name aangetrokken om de schommelingen in de bedrijfsdrukte op te volgen. De belangrijkste reden voor het geven van tijdelijke contracten is de mogelijkheid van een proeftijd alvorens iemand een vaste aanstelling krijgt.

2. Deeltijdwerk wordt gedefinieerd als een werkweek van meer dan 12 uur en minder dan 32 uur. 
Tabel 1.7

Kenmerken van dienstverbanden in de Metalektro, naar bedrijfssector, gemiddelde 1999-2000

\begin{tabular}{|c|c|c|c|c|c|c|}
\hline Kenmerk & $\begin{array}{l}\text { Basis- } \\
\text { metaal }\end{array}$ & $\begin{array}{l}\text { Metaal- } \\
\text { producten }\end{array}$ & $\begin{array}{l}\text { Machine- } \\
\text { industrie }\end{array}$ & $\begin{array}{l}\text { Elektro- } \\
\text { techniek }\end{array}$ & $\begin{array}{l}\text { Transport- } \\
\text { middelen }\end{array}$ & Metalektro \\
\hline Deeltijd & - & 9 & 7 & 12 & 7 & 9 \\
\hline Voltijd & - & 91 & 93 & 88 & 93 & 91 \\
\hline Flexibel* & 6 & 6 & 6 & 9 & 7 & 7 \\
\hline Vast $^{*}$ & 94 & 94 & 94 & 91 & 93 & 93 \\
\hline
\end{tabular}

\subsection{Belangrijkste beroepen en opleidingen}

Tabel 1.8 geeft een overzicht van de meest voorkomende beroepen binnen de Metalektro. Bij de beroepsgroepen die het CBS (zie ook bijlage B voor de gebruikte classificaties) onderscheidt zijn Metaalarbeiders, monteurs en bankwerkers en lassers verreweg de grootste beroepsgroepen binnen de Metalektro. Ook het aandeel van het niet-technische beroep boekhouders en secretaresses is met $5 \%$ aanzienlijk. In het algemeen is ongeveer $20-25 \%$ van de werkgelegenheid in de Metalektro niet-technisch van aard is. Het gaat hierbij voornamelijk om administratieve of ondersteunende beroepen. Tevens geldt dat een beroep niet in elk van de 5 sectoren binnen de Metalektro een even groot aandeel in de werkgelegenheid heeft. Zo is de beroepsgroep metaalarbeiders vooral belangrijk binnen metaalproducten, waar ze liefst $29 \%$ van de werkgelegenheid voor haar rekening neemt. Bankwerkers en lassers komen vooral veel voor in de basismetaal; elektromonteurs en productiemedewerkers vooral in elektrotechniek, en de assembleurs vooral in de sector transportmiddelen.

Tabel 1.9 geeft een overzicht van de belangrijkste opleidingsachtergronden van de werkenden binnen de Metalektro. De meest voorkomende opleidingsachtergronden voor werkenden zijn Basisonderwijs, VMBO mechanische techniek en MBO werktuigbouw en mechanische techniek, elk met een aandeel van $10 \%$ of meer binnen de Metalektro. Daarnaast zijn er ook werkenden met verzorgende en economisch-administratieve opleidingen. De opleidingen $M B O$ elektrotechniek en $H B O$ elektrotechniek zijn logischerwijs vooral belangrijk binnen de sector elektrotechniek, terwijl er vooral in de basismetaal relatief veel ongeschoolden met alleen basisonderwijs werkzaam zijn. 
Tabel 1.8

Belangrijkste beroepsgroepen binnen de Metalektro (naar percentage in de werkgelegenheid), gemiddelde 1999-2000

Beroepsgroep

$\%$

Metaalarbeiders

18

Monteurs

Bankwerkers en lassers

Boekhouders en secretaresses

Commercieel medewerkers (MBO niveau)

Commercieel medewerkers (HBO niveau)

Elektromonteurs

Productiemedewerkers

Werktuigbouwkundig ontwerpers en hoofden technische dienst

Installateurs

Medisch laboranten

Assembleurs

Chauffeurs

Laders en lossers

Productieplanners

Receptionisten en administratieve medewerkers

Systeemanalisten

* Een beroepsgroep is alleen opgenomen als het aandeel van de beroepsgroep binnen de Metalektro minimaal $2 \%$ bedraagt.

Bron: CBS/Enquête Beroepsbevolking (EBB) 1999 en 2000

Tabel 1.9

Belangrijkste hoogst genoten opleidingstypen binnen de Metalektro (naar percentage in de werkgelegenheid), gemiddelde 1999-2000

Opleidingstype

$\mathrm{MBO}$ werktuigbouw en mechanische techniek

Basisonderwijs

10

VMBO mechanische techniek

MBO elektrotechniek

VMBO theorie

HAVO/VWO

HBO werktuigbouwkunde

MBO administratie

MBO handel

VMBO bouwtechniek

VMBO elektrotechniek

VMBO (uiterlijke) verzorging

MBO bouw

MBO motorvoertuigentechniek

HBO elektrotechniek

HBO bedrijfskunde $2 \%$ bedraagt.

Bron: CBS/Enquête Beroepsbevolking (EBB) 1999 en 2000 


\section{Veranderingen in het personeelsbestand in 2002}

\section{$2.1 \quad$ Inleiding}

De Metalektro is een sector met een aanzienlijke dynamiek in het personeelsbestand. Bedrijven krijgen te maken met veranderingen in omzet, productlijn, technologie en organisatie. leder kwartaal vertrekken er werknemers uit de bedrijven en worden er nieuwe werknemers aangenomen. In dit hoofdstuk wordt de ontwikkeling van deze in- en uitstroom van personeel in de Metalektro in 2002 in kaart gebracht.

Allereerst wordt in paragraaf 2.2 nagegaan in hoeverre bedrijven in 2001 te maken hebben gehad met veranderingen in omzet, productlijn, technologie en organisatie en welke gevolgen deze veranderingen hebben gehad voor het personeelsbestand van deze bedrijven. Het is immers niet ondenkbaar dat dergelijke veranderingen ervoor zorgen dat het personeelsbestand moet worden uitgebreid of juist ingekrompen, of dat er herplaatsing van personeel plaatsvindt en personeel om- of bijgeschoold moet worden. In paragraaf 2.3 komt de instroom van nieuwe werknemers in de Metalektro aan bod. Naast een beschrijving van de aantallen nieuwe werknemers, wordt nagegaan wat de herkomst van deze werknemers is. Ten slotte volgt in paragraaf 2.4 een beschrijving van de ontwikkeling van de personeelsuitstroom in de Metalektro in het jaar 2002. Per kwartaal wordt in kaart gebracht hoeveel werknemers uit de bedrijven vertrokken zijn en hoe dit de dynamiek in de sector beïnvloedt. Ook wordt er aandacht besteed aan de reden van vertrek, waarbij nader ingegaan wordt op het probleem van de vergrijzing.

\subsection{Gevolgen van veranderingen in de bedrijven}

Bedrijven in de Metalektro staan niet stil. Ze proberen hun omzet te vergroten en hun bedrijf organisatorisch zo goed mogelijk te runnen. Veranderingen in de producten die men maakt en technologische vernieuwingen van het productieproces zijn daarbij onontbeerlijk. In deze paragraaf gaan we in op de vraag in hoeverre er in 2001 veranderingen in omzet, productlijn, technologie en organisatie in de Metalektro zijn geweest en welke gevolgen deze veranderingen hadden voor het personeelsbestand in de Metalektro.

\section{Veranderingen in omzet}

De omzet van bedrijven in de Metalektro in 2001 lag tussen de 2 en 608 miljoen euro. Gemiddeld haalden bedrijven in dat jaar een omzet van 38,5 miljoen euro. Figuur 2.1 laat zien dat in meer dan de helft van de bedrijven de omzet tussen 2000 en 2001 gestegen is; in bijna één op de vijf bedrijven zelfs in sterke mate. 13\% van de bedrijven meldt dat de omzet in 2001 gelijk is aan de omzet in 2000 . In één op de drie bedrijven is de omzet gedaald. Tussen grote en kleine bedrijven hebben zich geen opmerkelijke verschillen in omzetstijging of -daling voorgedaan. Ook zijn er 
geen duidelijke regionale verschillen of verschillen tussen de bedrijfssectoren binnen de Metalektro.

Figuur 2.1

Omzet in 2001 vergeleken met de omzet in 2000

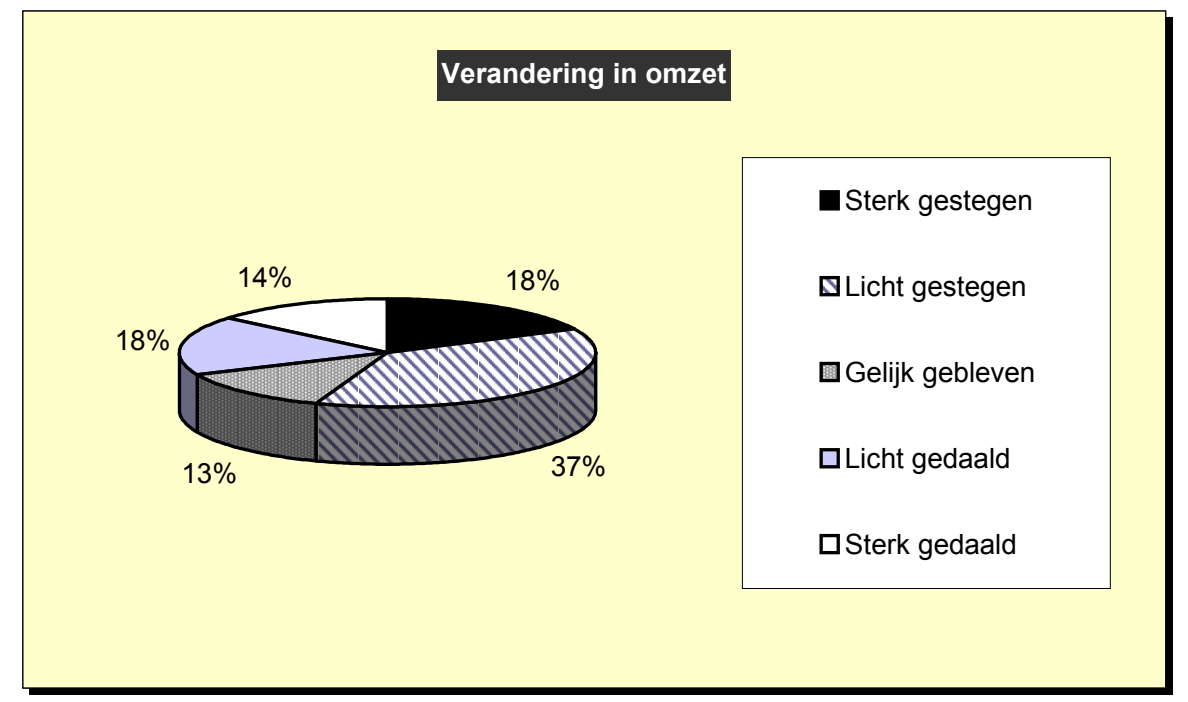

Bron: ROA/Werkgeverspanel Metalektro 2002

Tabel 2.1 toont aan dat de hoogte van de omzet die bedrijven in 2001 haalden, samenhangt met veranderingen in de omzet in het jaar daarvoor. Bedrijven met weinig omzet hebben vaak te maken met een omzetdaling. Zo was er bij iets meer dan de helft van de bedrijven met een omzet van $€ 10$ miljoen of lager sprake van een daling van de omzet. De bedrijven met een omzet tussen de 10 en 50 miljoen euro hebben voor het overgrote deel te maken met een omzetstijging. Ook bedrijven met een omzet van $€ 50$ miljoen of meer kennen in de meeste gevallen een omzetstijging, maar een aanzienlijk deel van deze bedrijven heeft ook met een gelijkblijvende omzet te maken.

Tabel 2.1

Hoogte van de omzet in 2001 en veranderingen in omzet tussen 2000 en 2001

\begin{tabular}{lccc}
\hline Omzet & $\begin{array}{c}\text { Omzet gestegen } \\
\%\end{array}$ & $\begin{array}{c}\text { Omzet gelijk } \\
\%\end{array}$ & $\begin{array}{c}\text { Omzet gedaald } \\
\%\end{array}$ \\
\hline Minder dan $€ 10$ miljoen omzet & 41 & 6 & 53 \\
$€ 10$ tot 20 miljoen omzet & 61 & 18 & 21 \\
$€ 20$ tot 50 miljoen omzet & 76 & 9 & 15 \\
$€ 50$ miljoen omzet of meer & 50 & 31 & 19 \\
Totaal & 58 & 14 & 28 \\
\hline
\end{tabular}

Bron: ROA/Werkgeverspanel Metalektro 2002 
In hoeverre hebben deze veranderingen in de omzet nu volgens de bedrijven in de Metalektro gevolgen gehad voor het personeelsbestand? Tabel 2.2 laat zien dat $41 \%$ van de bedrijven, die met een omzetstijging te maken hebben gehad, hun personeelsbestand uitgebreid hebben. 59\% van de bedrijven heeft de toename van de omzet dus weten te realiseren door het verhogen van de arbeidsproductiviteit. In één op de tien bedrijven met een omzetstijging heeft een herschikking van functies plaatsgevonden. Dit blijkt bij slechts een beperkt aantal bedrijven gepaard te gaan met herplaatsing en omscholing van personeel. Overigens meldt $57 \%$ van de bedrijven met een omzetstijging geen directe gevolgen voor hun personeelsbestand.

Tabel 2.2

Gevolgen voor het personeelsbestand door veranderingen in omzet in 2001*

\begin{tabular}{lcc}
\hline Gevolgen voor personeelsbestand & $\begin{array}{c}\text { Omzetstijging } \\
\%\end{array}$ & $\begin{array}{c}\text { Omzetdaling } \\
\%\end{array}$ \\
\hline Uitbreiding van personeel & 41 & 3 \\
Inkrimping zonder gedwongen ontslagen & 2 & 27 \\
Inkrimping met gedwongen ontslagen & 0 & 30 \\
Herplaatsing van personeel & 3 & 12 \\
Herschikking van functies & 10 & 16 \\
Om- en bijscholing van personeel & 4 & 10 \\
Geen direct gevolg & 57 & 43
\end{tabular}

* De verschillende percentages staan los van elkaar en hoeven dus niet op te tellen tot $100 \%$. Bron: ROA/Werkgeverspanel Metalektro 2002

Een omzetdaling heeft voor beduidend meer bedrijven gevolgen voor het personeel. Zo geeft $57 \%$ van de bedrijven aan dat de omzetdaling directe gevolgen voor hun personeelsbestand heeft gehad. Het gaat dan met name om het afvloeien van werknemers. $\mathrm{Bij} 27 \%$ van de bedrijven met een omzetdaling is het personeelsbestand ingekrompen zonder gedwongen ontslagen. 30\% van de bedrijven met een dalende omzet geeft aan het personeelsbestand te hebben ingekrompen met gedwongen ontslagen. Daarnaast is $16 \%$ van deze bedrijven overgegaan tot een herschikking van functies, die vaak gepaard gaan met een herplaatsing (12\%) en om- en bijscholing van het personeel (10\%).

\section{Veranderingen in productlijn}

Bedrijven kunnen ook veranderingen in hun productlijn doorvoeren. Tabel 2.3 laat zien dat dit in 2001 bij twee op de vijf bedrijven in de Metalektro het geval geweest is. $36 \%$ van de bedrijven meldt dat ze in 2001 nieuwe producten zijn gaan produceren, terwijl ongeveer één op de tien bedrijven producten uit het pakket verwijderd heeft. In $9 \%$ van de bedrijven was er sprake van zowel nieuwe producten als van producten die niet meer geproduceerd worden. Uit de tabel blijkt ook dat grote bedrijven vaker veranderingen in de productlijn doorvoeren dan de kleinere bedrijven. Daarentegen zijn er geen duidelijke verschillen tussen bedrijven uit de diverse sectoren binnen de Metalektro en regionale verschillen gevonden. 
Tabel 2.3

Veranderingen in productlijn in 2001, naar bedrijfsomvang*

\begin{tabular}{lcccc}
\hline Verandering in productlijn & $\begin{array}{c}0-100 \\
\text { werknemers } \\
\%\end{array}$ & $\begin{array}{c}101-250 \\
\text { werknemers } \\
\%\end{array}$ & $\begin{array}{c}251 \text { en meer } \\
\text { werknemers } \\
\%\end{array}$ & $\begin{array}{c}\text { Totaal } \\
\%\end{array}$ \\
\hline Nieuwe producten in het pakket & 28 & 44 & 56 & 36 \\
Producten uit het pakket verwijderd & 6 & 8 & 41 & 11 \\
Geen verandering in productlijn & 71 & 56 & 27 & 61
\end{tabular}

* De verschillende percentages staan los van elkaar en hoeven dus niet op te tellen tot $100 \%$. Bron: ROA/Werkgeverspanel Metalektro 2002

Eén op de drie bedrijven, die in 2001 producten uit hun pakket verwijderd hebben, geeft aan dat dit gevolgen gehad heeft voor hun personeel. Gezien het kleine aantal bedrijven dat hiermee te maken heeft, is het niet mogelijk een uitsplitsing naar het soort gevolg te maken.

Tabel 2.4 laat de gevolgen zien voor de bedrijven die nieuwe producten in hun pakket opgenomen hebben. $65 \%$ van de bedrijven geeft aan dat het starten met nieuwe producten geen directe gevolgen gehad heeft voor hun personeel. $26 \%$ van de bedrijven geeft daarentegen aan hun personeelsbestand uitgebreid te hebben. Herschikking van functies en om- en bijscholing van personeel als gevolg van het introduceren van nieuwe producten vinden in $8 \%$ van de bedrijven plaats.

Tabel 2.4

Gevolgen voor het personeelsbestand door veranderingen in de productlijn in 2001*

Gevolgen voor personeelsbestand $\quad \begin{gathered}\text { Nieuwe producten in } \\ \text { pakket } \\ \%\end{gathered}$

Uitbreiding van personeel

Inkrimping zonder gedwongen ontslagen

Inkrimping met gedwongen ontslagen

Herplaatsing van personee

Herschikking van functies

Om- en bijscholing van personeel

26
5
0
6
8
8
65

Geen direct gevolg

65

* De verschillende percentages staan los van elkaar en hoeven dus niet op te tellen tot $100 \%$. Bron: ROA/Werkgeverspanel Metalektro 2002

\section{Technologische vernieuwing}

$\mathrm{Er}$ is ook nagegaan hoeveel bedrijven in 2001 een belangrijke technologische vernieuwing geïntroduceerd hebben. Het gaat dan om robotisering, automatisering of het inzetten van nieuwe machines of productielijnen. Tabel 2.5 laat zien dat dit bij $18 \%$ van de bedrijven in de Metalektro het geval geweest is. Ook hier geldt weer dat er opmerkelijke verschillen tussen grote en kleine bedrijven zijn. Van de bedrijven met meer dan 250 werknemers heeft $41 \%$ een belangrijke technologische 
vernieuwing ingevoerd. Bedrijven met minder dan 100 werknemers blijken minder innovatief: 12\% van deze kleinere bedrijven introduceerde in 2001 een belangrijke technologische vernieuwing in het productieproces.

Tabel 2.5

Introductie van een technologische vernieuwing in 2001, naar bedrijfsomvang*

\begin{tabular}{lc}
\hline Bedrijfsomvang & $\%$ \\
\hline $0-100$ werknemers & 12 \\
$101-250$ werknemers & 22 \\
251 of meer werknemers & 41 \\
Totaal & 18 \\
\hline
\end{tabular}

* De verschillende percentages staan los van elkaar en hoeven dus niet op te tellen tot $100 \%$. Bron: ROA/Werkgeverspanel Metalektro 2002

lets minder dan de helft van de bedrijven, die in 2001 een technologische vernieuwing introduceerde, geeft aan dat dit directe gevolgen voor hun personeelsbestand heeft gehad. Het is hier niet mogelijk een kwantitatieve uitsplitsing van de gevolgen te geven, maar het lijkt met name om de om- en bijscholing van personeel te gaan. Ook herplaatsing van werknemers en herschikking van functies komen voor, net als inkrimping van het personeelsbestand zonder gedwongen ontslagen. Enkele bedrijven zorgen voor een 'upgrading' van hun personeelsbestand door werknemers aan te trekken die voor de nieuwe technologie gekwalificeerd zijn.

\section{Organisatorische veranderingen}

Ten slotte is aan de bedrijven gevraagd of er in 2001 belangrijke organisatorische veranderingen in hun bedrijfsvestiging hebben plaatsgevonden. Ruim de helft van de bedrijven in de Metalektro geeft aan dat dit inderdaad het geval geweest is. Zo heeft in $28 \%$ van de bedrijven een interne reorganisatie plaatsgevonden. Ongeveer één op de tien bedrijven is in 2001 overgenomen door een ander bedrijf en zo'n 7\% heeft zelf een ander bedrijf overgenomen. Uitbesteding van een deel van het productieproces naar het buitenland vindt in $6 \%$ van de bedrijven plaats, terwijl $2 \%$ van bedrijven een deel van het productieproces uitbesteedt aan andere bedrijven in Nederland. Opmerkelijk is dat grote bedrijven niet beduidend meer met organisatorische veranderingen te maken krijgen dan kleine bedrijven. Ook zijn er geen verschillen gevonden tussen bedrijven in de verschillende sectoren en regio's.

Zoals gezegd, heeft bijna 30\% van de bedrijven in de Metalektro in 2001 een interne reorganisatie doorgevoerd. Tabel 2.6 laat zien dat deze reorganisaties in $65 \%$ van de bedrijven gevolgen hebben gehad voor het personeelsbestand van het bedrijf. In de meeste gevallen gaat het om een herschikking van functies $(39 \%)$ of herplaatsing van personeel $(27 \%)$. Daarnaast gaat een interne reorganisatie ook vaak gepaard met een inkrimping van het personeelsbestand. Maar liefst $37 \%$ van de bedrijven waar zich een reorganisatie heeft voorgedaan meldt dat dit gepaard is gegaan met gedwongen ontslagen. Nog eens $15 \%$ geeft aan dat er inkrimping heeft plaatsge- 
vonden zonder gedwongen ontslagen. Ten slotte heeft in bijna één op de vijf bedrijven de interne reorganisatie geleid tot het om- en bijscholen van werknemers.

Figuur 2.2

Organisatorische veranderingen in 2001

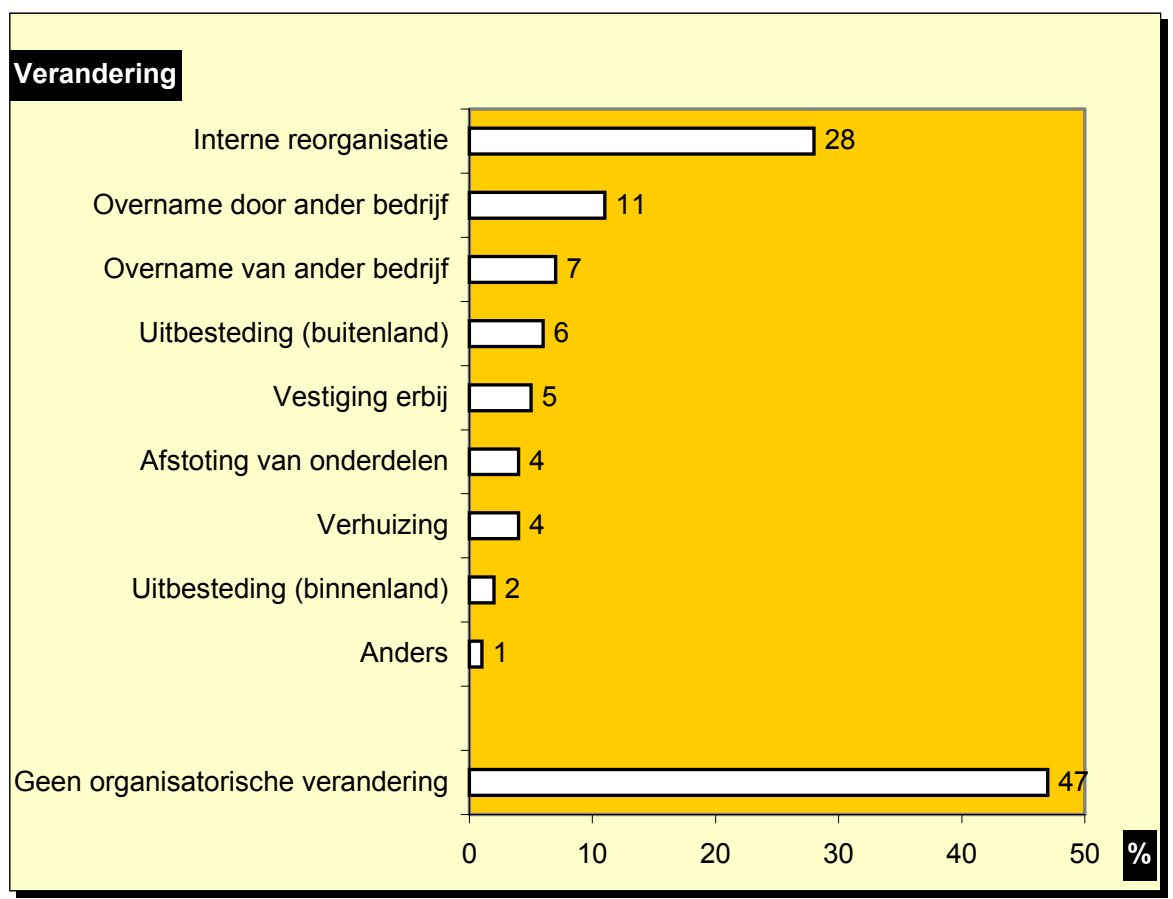

Bron: ROA/Werkgeverspanel Metalektro 2002

Tabel 2.6

Gevolgen voor het personeelsbestand door interne reorganisatie in 2001*

Gevolgen voor personeelsbestand Interne reorganisatie $\%$

Uitbreiding van personeel

Inkrimping zonder gedwongen ontslagen

Inkrimping met gedwongen ontslagen

Herplaatsing van personeel

Herschikking van functies

8

Om- en bijscholing van personeel

37

Geen direct gevolg

${ }^{*}$ De verschillende percentages staan los van elkaar en hoeven dus niet op te tellen tot $100 \%$. Bron: ROA/Werkgeverspanel Metalektro 2002

\subsection{Instroom in de Metalektro}

In deze paragraaf komt de instroom van nieuwe werknemers in de Metalektro aan bod. Figuur 2.3 laat zien dat de grootste groep nieuwkomers betrekking heeft op de uitvoerende technici, zoals monteurs, productiemedewerkers en metaalarbeiders. 
Aangezien de meeste werknemers in de Metalektro werkzaam zijn in uitvoerende technische functies, is deze grote instroom niet verwonderlijk. De instroom van werknemers in deze functies is met name groot in het derde kwartaal, niet alleen in absolute aantallen (3.520), maar ook relatief gezien. De instroom van werknemers in ondersteunende, administratieve of commerciële functies is eveneens aanzienlijk. Opvallend is wel dat de instroom in deze functies in het derde kwartaal van 2002 een stuk lager ligt dan in de rest van het jaar. Het aantal nieuwe leidinggevende technici dat bij bedrijven in de Metalektro aangenomen wordt, verdubbelt in de loop van 2002 van 150 in het eerste kwartaal tot 300 in het vierde kwartaal. De instroom in managementfuncties ten slotte blijft ongeveer stabiel op zo'n 175 nieuwe werknemers per kwartaal.

Figuur 2.3

Aantal nieuwe werknemers per kwartaal in 2002, naar beroepscategorie

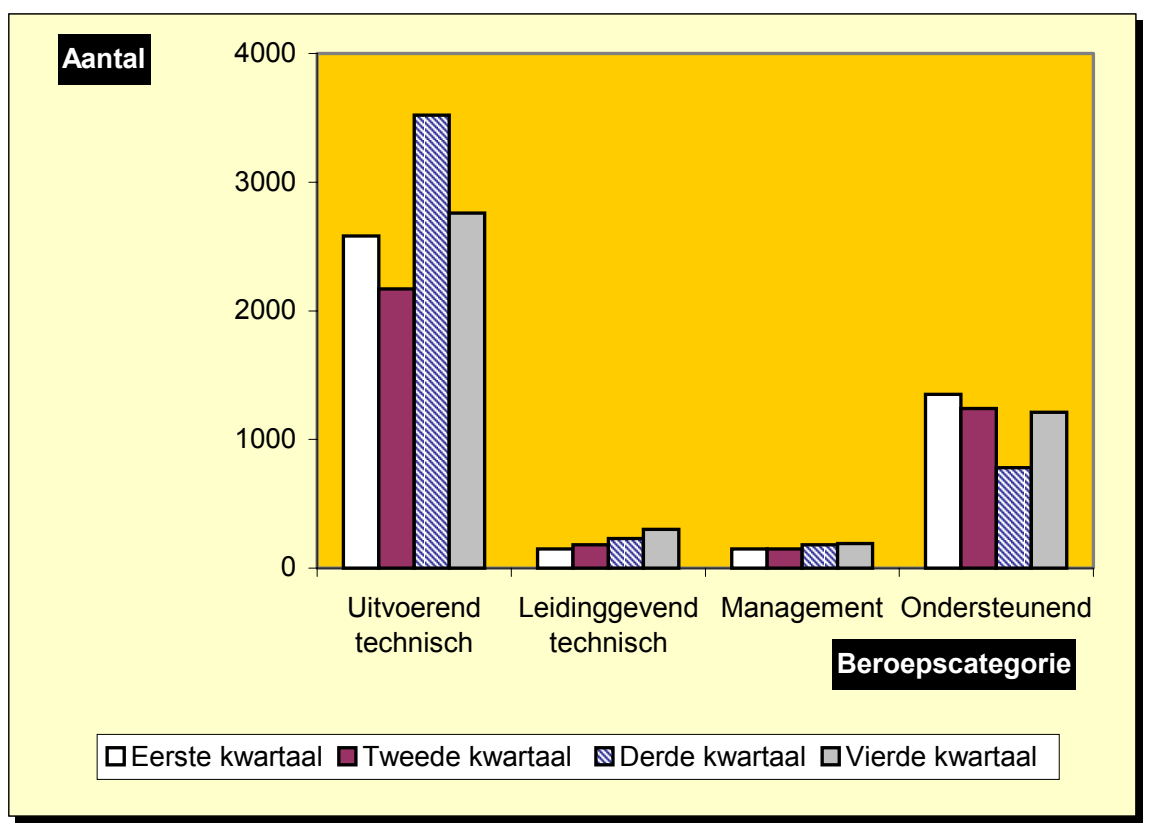

Bron: ROA/Werkgeverspanel Metalektro 2002

In totaal werden er in het eerste kwartaal van 2002 bijna 4.250 nieuwe werknemers aangenomen. In het tweede kwartaal daalde dit aantal naar iets minder dan 3.750, om vervolgens in het derde kwartaal weer te stijgen naar zo'n 4.700 nieuwe werknemers. In het vierde kwartaal van 2002 bedroeg de instroom 4.400 werknemers. Uit tabel 2.7 blijkt dat in de meeste kwartalen zeven van de tien bedrijven in de Metalektro nieuwe werknemers aangetrokken heeft. Alleen in het eerste kwartaal van 2002 zijn dit er aanzienlijk minder; slechts de helft van de bedrijven neemt dan nieuwe werknemers aan. Dit is opmerkelijk, aangezien het aantal werknemers dat in het eerste kwartaal ingestroomd is vrij hoog ligt. Dit betekent dat de bedrijven die in het eerste kwartaal nieuwe werknemers aangenomen hebben, een grote instroom kenden. 
Tabel 2.7

Bedrijven met nieuwe werknemers per kwartaal in 2002, naar beroepscategorie*

\begin{tabular}{lcccc}
\hline Beroepscategorie & $\begin{array}{c}\text { Eerste } \\
\text { kwartaal } \\
\%\end{array}$ & $\begin{array}{c}\text { Tweede } \\
\text { kwartaal } \\
\%\end{array}$ & $\begin{array}{c}\text { Derde } \\
\text { kwartaal } \\
\%\end{array}$ & $\begin{array}{c}\text { Vierde } \\
\text { kwartaal } \\
\%\end{array}$ \\
\hline Uitvoerende technische functies & 33 & 46 & 60 & 50 \\
Leidinggevende technische functies & 10 & 12 & 20 & 17 \\
Management functies & 8 & 10 & 14 & 15 \\
Ondersteunende functies & 34 & 47 & 33 & 39 \\
Totaal & 50 & 70 & 70 & 71
\end{tabular}

${ }^{*}$ De verschillende percentages staan los van elkaar en hoeven dus niet op te tellen tot $100 \%$. Bron: ROA/Werkgeverspanel Metalektro 2002

Gemiddeld genomen namen bedrijven in 2002 ongeveer vier nieuwe werknemers per kwartaal aan. Grote bedrijven nemen, zoals verwacht mag worden, meer nieuwe werknemers aan. Opvallend hierbij is dat de middelgrote bedrijven (tussen de 100 en 250 medewerkers) de meeste nieuwe uitvoerende technici aannemen. Er zijn geen grote verschillen tussen sectoren binnen de Metalektro gevonden. Een uitzondering hierop vormen de bedrijven in de machine-industrie, die in het derde kwartaal van 2002 minder nieuwe technici, zowel uitvoerenden als leidinggevenden, hebben aangenomen.

\section{Herkomst van nieuwe werknemers}

Waar komen al deze nieuwe werknemers in de Metalektro vandaan? Tabel 2.8 laat zien dat het grootste deel van de technici die bedrijven in 2002 aangetrokken hebben, daarvoor reeds elders in de Metalektro werkzaam was. In de loop van 2002 is het aantal technici dat van het ene bedrijf naar het andere bedrijf overstapt echter wel gedaald. Het aandeel van deze groep in de totale instroom neemt daardoor af van $50 \%$ in het eerste kwartaal naar $34 \%$ in het vierde kwartaal. Daarentegen is $30 \%$ tot $40 \%$ van de instroom afkomstig van bedrijven buiten de Metalektro. In het vierde kwartaal van 2002 ging het om 1.100 technici. Kennelijk heeft de Metalektro een duidelijke wervingskracht op de arbeidsmarkt voor technisch personeel.

Naast het aantrekken van nieuwe technische werknemers die over enige werkervaring beschikken, nemen bedrijven ook schoolverlaters aan. Met name in het derde kwartaal van 2002 stromen veel schoolverlaters de Metalektro in, namelijk zo'n kleine 800. In het derde kwartaal blijken bovendien de werklozen een groter deel van het nieuw aangetrokken technisch personeel uit te maken dan in de overige kwartalen van 2002. Het gaat daarbij om iets minder dan 450 werklozen. Herintreders en (gedeeltelijk) arbeidsongeschikten vormen slechts een zeer klein deel van de instroom in de Metalektro. Overigens meldt $54 \%$ van de bedrijven wel mogelijkheden te zien voor de plaatsing van langdurig werklozen in hun bedrijf. De mogelijkheden voor de plaatsing van arbeidsongeschikten zijn volgens de bedrijven veel geringer; slechts $8 \%$ ziet hiervoor enigszins mogelijkheden. 
Tabel 2.8

Herkomst van nieuwe technische werknemers per kwartaal in 2002

\begin{tabular}{lcccr}
\hline Herkomst & $\begin{array}{c}\text { Eerste } \\
\text { kwartaal } \\
\%\end{array}$ & $\begin{array}{c}\text { Tweede } \\
\text { kwartaal } \\
\%\end{array}$ & $\begin{array}{c}\text { Derde } \\
\text { kwartaal } \\
\%\end{array}$ & $\begin{array}{c}\text { Vierde } \\
\text { kwartaal } \\
\%\end{array}$ \\
\hline Andere vestiging bedrijf & - & 2 & 1 & 2 \\
Ander bedrijf binnen de Metalektro & 50 & 40 & 29 & 34 \\
Ander bedrijf buiten de Metalektro & 31 & 35 & 27 & 40 \\
Schoolverlater & 7 & 10 & 23 & 12 \\
Werkloze & 6 & 4 & 13 & 5 \\
Herintreder & 0 & 2 & 1 & 2 \\
(Gedeeltelijk) arbeidsongeschikt & 1 & 2 & 3 & 0 \\
Anders & 6 & 6 & 3 & 5 \\
\hline
\end{tabular}

- Geen gegevens beschikbaar.

Bron: ROA/Werkgeverspanel Metalektro 2002

Werkgevers in de Metalektro blijken bij het aantrekken van personeel vaak veel waarde te hechten aan de werkervaring van mensen. Tabel 2.9. laat zien dat ruim driekwart van de bedrijven de voorkeur geven aan werkenden met relevante werkervaring. In de metaalproductensector ligt dit aandeel wat lager: $40 \%$ van de bedrijven in deze sector geeft aan dat ze schoolverlaters met een relevant vakdiploma prefereren. Er zijn geen duidelijke verschillen tussen grote en kleine bedrijven in de voorkeur voor een schoolverlater of een werkende.

Tabel 2.9

Voorkeur bij het invullen van vacatures voor technisch personeel, naar bedrijfssector

\begin{tabular}{lcc}
\hline Sector & $\begin{array}{c}\text { Schoolverlater met } \\
\text { relevant vakdiploma } \\
\%\end{array}$ & $\begin{array}{c}\text { Werkende met } \\
\text { relevante werkervaring } \\
\%\end{array}$ \\
\hline Metaalproducten & 38 & 62 \\
Machine-industrie & 24 & 76 \\
Overige sectoren & 19 & 81 \\
Totaal & 23 & 77 \\
\hline
\end{tabular}

Bron: ROA/ Werkgeverspanel Metalektro 2002

\section{$2.4 \quad$ Uitstroom in de Metalektro}

Figuur 2.4 geeft per kwartaal een overzicht van het aantal werknemers dat in 2002 bij een bedrijf in de Metalektro is vertrokken, uitgesplitst naar de vier belangrijke beroepscategorieën. In totaal vertrokken er in het eerste kwartaal van 2002 zo'n 5.700 werknemers bij hun bedrijf. In het tweede kwartaal nam dit aantal toe tot 7.000 , om daarna te zakken naar 6.200 in het derde kwartaal en 5.900 in het vierde kwartaal van 2002. De grootste uitstroom doet zich voor bij de uitvoerende technici. De uitstroom uit deze functies blijkt met name groot te zijn in het tweede en derde kwartaal van 2002. Het gaat dan om respectievelijk bijna 4.700 en 4.250 uitvoerende technici. In het vierde kwartaal daalt de uitstroom weer sterk, naar bijna 3.000 werknemers. Het personeelsverloop onder uitvoerende technici is dan zelfs minder 
dan men op grond van de aantallen werkenden in deze beroepscategorie zou verwachten.

Figuur 2.4

Aantal vertrokken werknemers per kwartaal in 2002, naar beroepscategorie

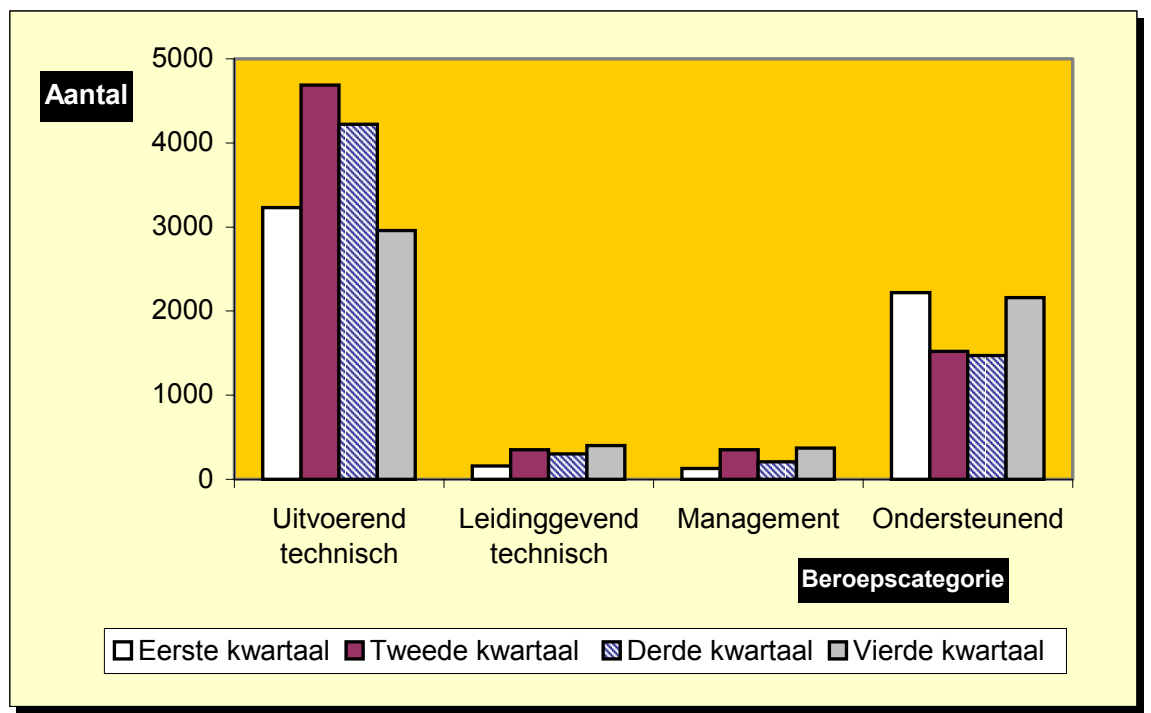

Bron: ROA/Werkgeverspanel Metalektro 2002

Ook de uitstroom van werknemers in ondersteunende functies als secretaresses, receptionisten, boekhouders, inkoop-verkoop medewerkers en schoonmakers is aanzienlijk. Het is opmerkelijk dat het seizoenspatroon in het personeelsverloop bij deze functies duidelijk afwijkt van het seizoenspatroon in het verloop van het uitvoerend technisch personeel. Met name in het eerste en het vierde kwartaal van 2002 vertrekken er veel werknemers uit deze functies (respectievelijk 2.200 en 2.160). De uitstroom uit leidinggevende technische functies (zoals voormannen, opzichters en werkbazen) en management functies is met name hoog in het tweede en vierde kwartaal van 2002. Het personeelsverloop in deze twee beroepscategorieën is in overeenstemming met hun omvang, al blijken er in het vierde kwartaal relatief gezien veel werknemers uit managementfuncties te vertrekken.

Dat een meerderheid van de bedrijven in de Metalektro in 2002 met vertrekkende werknemers te maken heeft, blijkt uit tabel 2.10. Het percentage bedrijven met personeelsuitstroom neemt zelfs toe van $64 \%$ in het eerste kwartaal tot $79 \%$ in het vierde kwartaal van 2002. Met name het percentage bedrijven waar werknemers uit managementfuncties vertrekken stijgt flink, namelijk van $9 \%$ tot $23 \%$.

Gemiddeld stromen er per bedrijf ongeveer vijf werknemers per kwartaal uit. Alleen in het tweede kwartaal van 2002 lag dit aantal hoger. Toen vertrokken er gemiddeld ruim 11 werknemers per bedrijf. Natuurlijk speelt opnieuw de omvang van het bedrijf een rol bij deze cijfers. Grote bedrijven hebben een hoger personeelsverloop in alle vier de beroepscategorieën. Verder blijkt dat bedrijven die metaalproducten maken 
beduidend minder uitstroom kennen dan bedrijven in de machine-industrie of overige sectoren. De regionale verschillen zijn minder opvallend en wisselen ook per kwartaal. Over het algemeen is de personeelsuitstroom in het Noorden wat kleiner dan in de rest van het land.

Tabel 2.10

Bedrijven met vertrekkende werknemers per kwartaal in 2002, naar beroepscategorie*

\begin{tabular}{lcccc}
\hline Beroepscategorie & $\begin{array}{c}\text { Eerste } \\
\text { kwartaal } \\
\%\end{array}$ & $\begin{array}{c}\text { Tweede } \\
\text { kwartaal } \\
\%\end{array}$ & $\begin{array}{c}\text { Derde } \\
\text { kwartaal } \\
\%\end{array}$ & $\begin{array}{c}\text { Vierde } \\
\text { kwartaal } \\
\%\end{array}$ \\
\hline Uitvoerende technische functies & 54 & 57 & 62 & 60 \\
Leidinggevende technische functies & 12 & 11 & 16 & 19 \\
Management functies & 97 & 49 & 16 & 23 \\
Ondersteunende functies & 37 & 73 & 76 & 43 \\
Totaal & 64 & & 79 & 79
\end{tabular}

* De verschillende percentages staan los van elkaar en hoeven dus niet op te tellen tot $100 \%$. Bron: ROA/Werkgeverspanel Metalektro 2002

De instroom van werknemers in de Metalektro blijft in alle kwartalen van 2002 duidelijk achter bij de uitstroom. Figuur 2.5 laat zien dat hierdoor het aantal werkenden afneemt. Met name in het tweede kwartaal is de daling in het aantal werkenden groot, namelijk zo'n 3.500 uitvoerende technici, 300 leidinggevende technici, 200 werknemers in managementfuncties en ruim 2.700 werknemers in ondersteunende functies. Dit betekent dat de werkgelegenheid in de Metalektro in 2002 gedaald is. Aan de andere kant zijn er echter nog steeds vacatures (zie ook hoofdstuk 3), hetgeen erop duidt dat er ondanks het teruglopen van de vraag nog steeds sprake is van een tekortschietend aanbod.

Opvallend is dat de daling in het aantal werknemers zich in alle sectoren binnen de Metalektro voordoet. Een uitzondering is de sector metaalproducten: in deze sector neemt in het derde kwartaal van 2002 het aantal werknemers met een uitvoerende technische functie toe. Grote bedrijven hebben vaker met een sterke daling van het aantal werkenden te maken dan kleine bedrijven. Dit blijkt met name in het derde en vierde kwartaal van 2002 het geval.

De instroom en uitstroom cijfers laten al zien dat er naast de 'netto' ontwikkeling van de werkgelegenheid sprake is van een grote dynamiek op de arbeidsmarkt. Figuur 2.6 geeft aan dat ook hier het tweede kwartaal van 2002 eruit springt. In totaal stroomden er toen bijna 14.250 werknemers bij bedrijven in de Metalektro in of uit. Met name bij het ondersteunend personeel blijkt er een grote dynamiek op de arbeidsmarkt te zijn. Grote bedrijven hebben overigens met een wat grotere in- en uitstroom van personeel te maken dan kleine bedrijven. Daarentegen kennen de bedrijven in de metaalproducten en de machine-industrie in het eerste en het vierde kwartaal van 2002 een kleinere dynamiek dan bedrijven in de overige sectoren binnen de Metalektro, maar dit geldt alleen voor uitvoerende technische werknemers. 
Figuur 2.5

Daling van het aantal werknemers per kwartaal in 2002, naar beroepscategorie

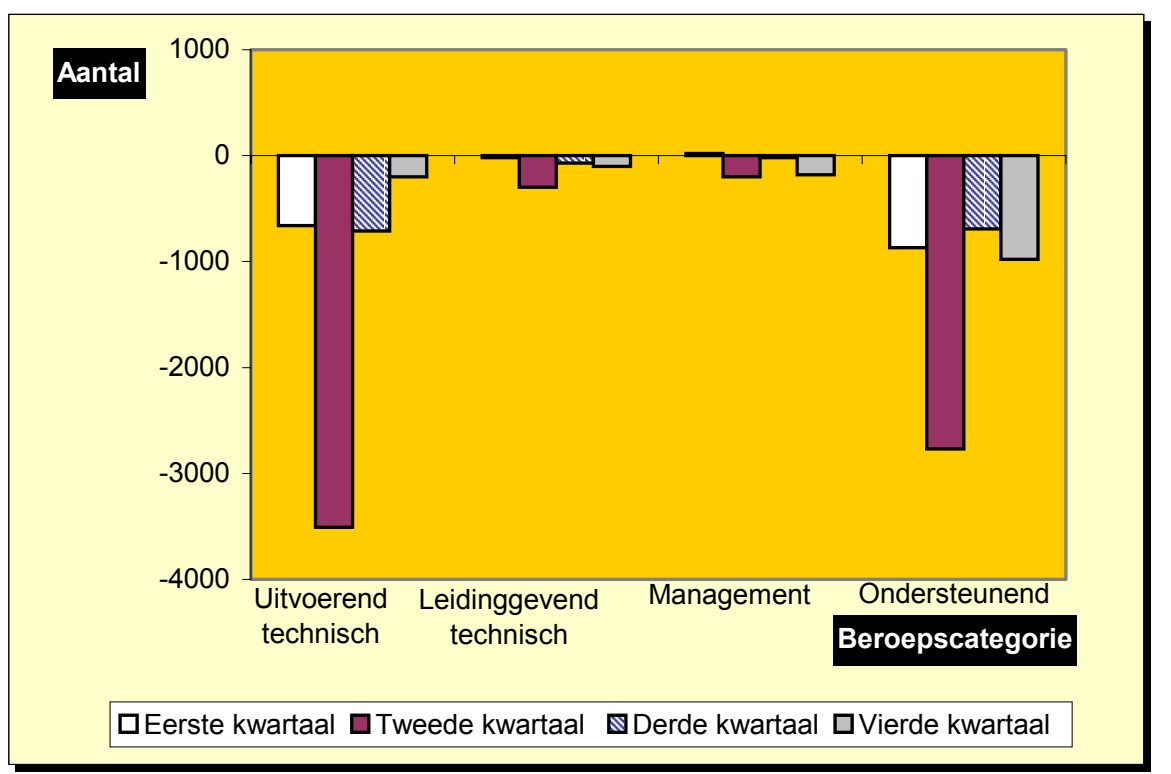

Bron: ROA/Werkgeverspanel Metalektro 2002

Figuur 2.6

Dynamiek (instroom plus uitstroom) op de arbeidsmarkt per kwartaal in 2002, naar beroepscategorie

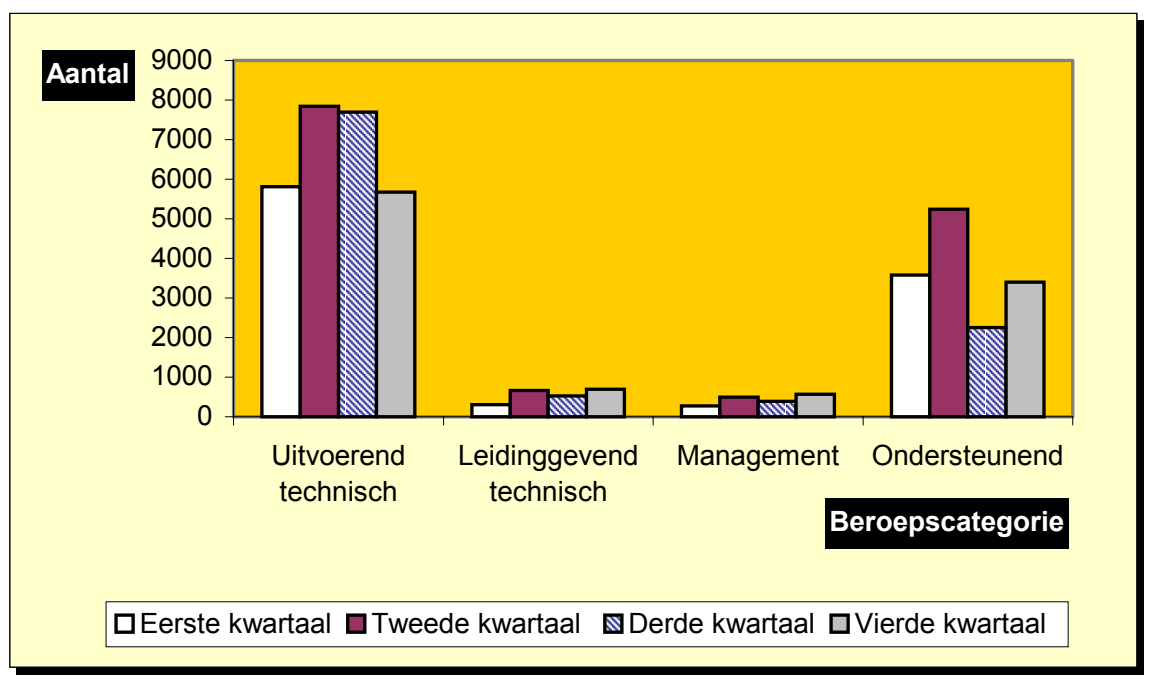

Bron: ROA/Werkgeverspanel Metalektro 2002

Is de uitstroom van personeel vanuit de optiek van de bedrijven in de Metalektro nu hoog of laag te noemen? Om dit na te gaan hebben we de bedrijven gevraagd zelf een inschatting van hun personeelsverloop te geven. Meer specifiek gaat het om de 
uitstroom van technische werknemers in het eerste kwartaal van 2002. Zoals figuur 2.7 laat zien, vinden verreweg de meeste bedrijven dat ze weinig (31\%) of zeer weinig tot geen personeelsverloop (42\%) hebben gehad. Slechts één op de tien bedrijven meldt dat er in het eerste kwartaal van 2002 veel technici vertrokken zijn. Met name de bedrijven in de machine-industrie vinden hun personeelsverloop hoog, net als bedrijven in de regio's Zuidwest en West. Ten slotte blijken grotere bedrijven (meer dan 250 werknemers) hun personeelsuitstroom eerder weinig dan veel te vinden.

Figuur 2.7

Subjectieve beoordeling van het personeelsverloop onder technische werknemers in het eerste kwartaal in 2002

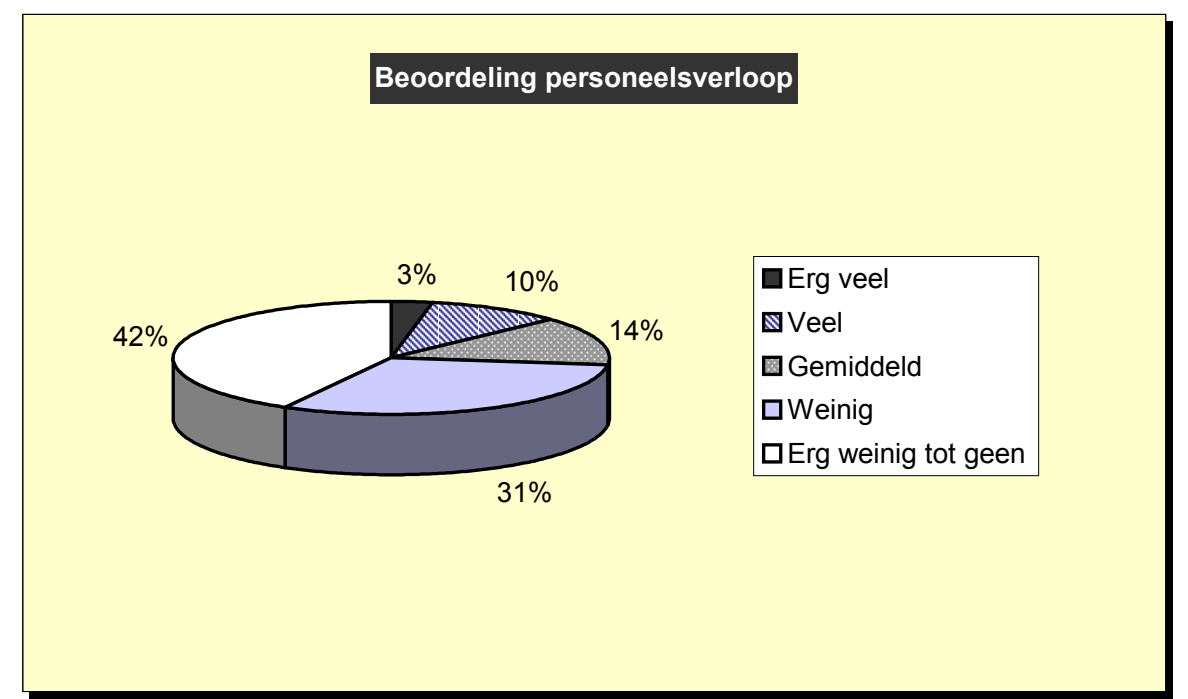

Bron: ROA/Werkgeverspanel Metalektro 2002

\section{Reden van vertrek technisch personeel}

Belangrijk is natuurlijk ook de vraag om welke redenen het technische personeel vertrekt. Tabel 2.11 laat zien dat ongeveer eenderde van hen vrijwillig ontslag aangevraagd heeft. Voor de gehele Metalektro gaat het dan om 1.100 à 1.200 werknemers per kwartaal, met uitzondering van het tweede kwartaal van 2002, toen de uitstroom hoger was en het aantal technici dat vrijwillig vertrok ruim 1.400 bedroeg. Het aflopen van een tijdelijk contract dat niet verlengd wordt, speelt bij één op de vijf vertrekkende technici een rol. Ook gedwongen ontslagen komen redelijk veel voor. Hierbij is het opvallend dat het percentage technische werknemers dat om deze reden uitstroomt in de loop van 2002 met 13 procentpunt afgenomen is, al gaat het daarbij nog altijd om zo'n 700 werknemers. Verder blijkt het aantal technici dat met (vervroegd) pensioen gaat juist toe te nemen. In het eerste kwartaal van 2002 was dit bij $10 \%$ van het uitstromend personeel de reden van vertrek. In het vierde kwartaal betrof het maar liefst $21 \%$. Wellicht heeft dit niet alleen te maken met de toenemende vergrijzing, maar ook met de economische situatie. Bedrijven die gedwongen worden hun personeelsbestand in te krimpen, hebben in het derde en vierde kwartaal van 
2002 beduidend meer technici vanwege pensionering zien vertrekken dan andere bedrijven. Oudere werknemers met pensioen of VUT laten gaan is blijkbaar vaak de eerste optie bij inkrimping.

Tabel 2.11

Reden van vertrek voor technische werknemers per kwartaal in 2002

\begin{tabular}{lcccc}
\hline Reden van vertrek & $\begin{array}{c}\text { Eerste } \\
\text { kwartaal } \\
\%\end{array}$ & $\begin{array}{c}\text { Tweede } \\
\text { kwartaal } \\
\%\end{array}$ & $\begin{array}{c}\text { Derde } \\
\text { kwartaal } \\
\%\end{array}$ & $\begin{array}{c}\text { Vierde } \\
\text { kwartaal } \\
\%\end{array}$ \\
\hline Vervroegd) pensioen & 10 & 16 & 19 & 21 \\
Gezondheidsredenen/arbeidsongeschiktheid & 7 & 3 & 9 & 6 \\
Overlijden & - & 1 & 2 & 2 \\
Gedwongen ontslag & 31 & 27 & 20 & 18 \\
Aflopen tijdelijk contract & 19 & 20 & 23 & 20 \\
Vrijwillig ontslag & 34 & 33 & 27 & 32
\end{tabular}

- Geen gegevens beschikbaar.

Bron: ROA/Werkgeverspanel Metalektro 2002

Figuur 2.8

Belangrijkste motief voor het vrijwillig vertrekken van technische werknemers in het eerste kwartaal van 2002

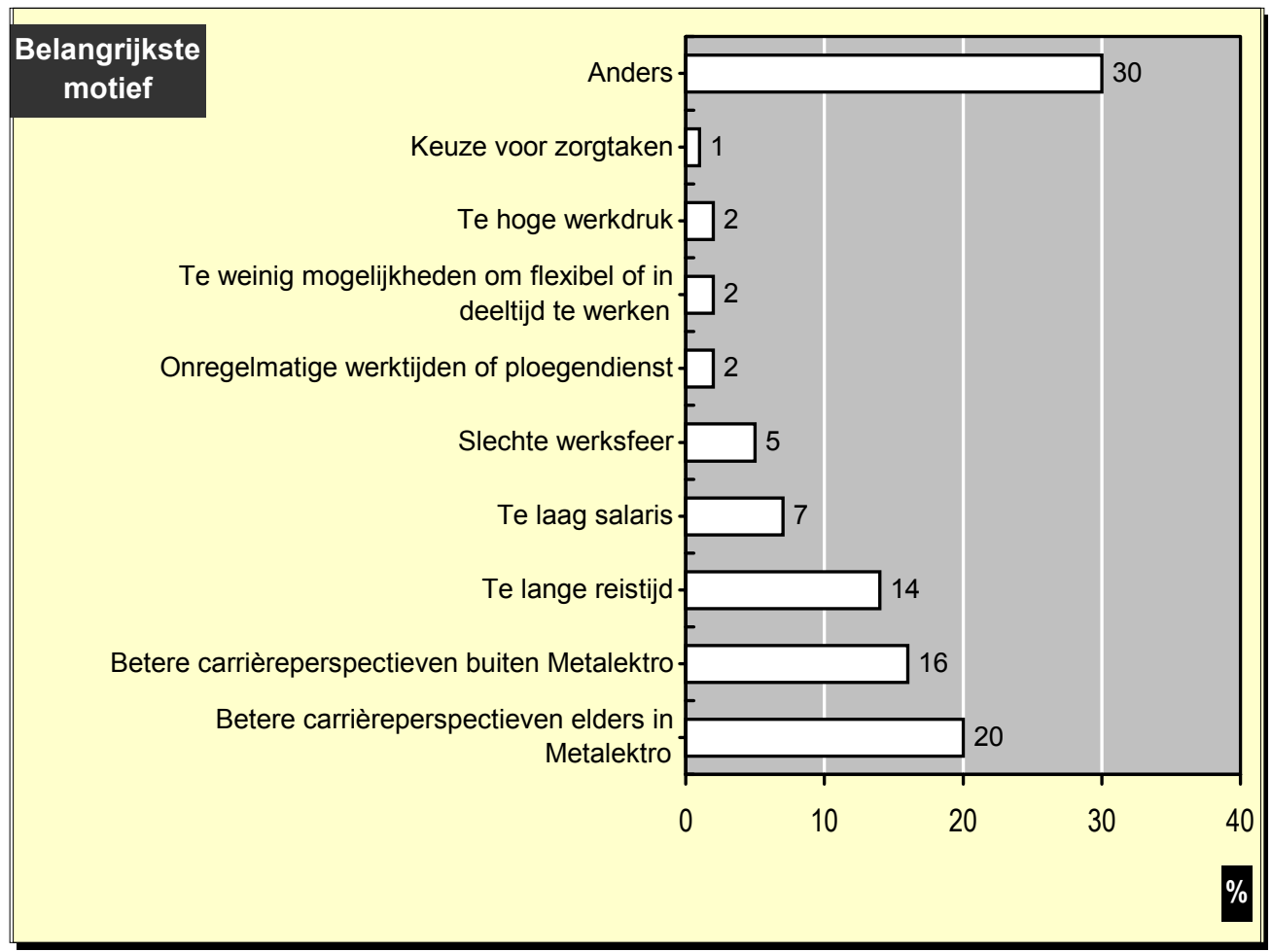

Bron: ROA/Werkgeverspanel Metalektro 2002 
Bij grote bedrijven is er vaker sprake van uitstroom vanwege (vervroegd) pensioen, gezondheidsredenen en vrijwillig ontslag dan bij kleinere bedrijven. Tussen de verschillende bedrijfssectoren in de Metalektro zijn geen duidelijke verschillen in de redenen waarom technisch personeel vertrekt. Ook zijn er geen regionale verschillen.

Zoals gezegd, vormt vrijwillig ontslag de belangrijkste reden van vertrek voor technische werknemers. Ongeveer $70 \%$ van de bedrijven in de Metalektro ziet om deze reden technici uitstromen. Figuur 2.8 laat zien dat het belangrijkste motief voor vrijwillig vertrek de betere carrièreperspectieven elders zijn. Zo vertrekken in één op de vijf bedrijven technische werknemers vrijwillig uit het bedrijf omdat ze betere carrièreperspectieven elders in de Metalektro zien, terwijl in 16\% van de bedrijven technisch personeel vertrekt omdat ze betere carrièreperspectieven buiten de Metalektro vinden. Daarna volgen als belangrijkste redenen voor vertrek de lange reistijd naar het werk (14\%), het te lage salaris $(7 \%)$ en de slechte werksfeer $(5 \%)$. $30 \%$ van de bedrijven geeft een ander motief als reden van vrijwillig vertrek op, zoals het beginnen van een eigen bedrijf, het toe zijn aan een nieuwe uitdaging in een andere branche en het zoeken van een andere baan vanwege de onzekere economische situatie in het bedrijf.

\section{Vergrijzing}

Zoals we zagen vormt pensionering een steeds belangrijkere reden waarom technici uitstromen. Had in het eerste kwartaal van 2002 één op de drie bedrijven te maken met technische werknemers die met (vervroegd) pensioen gingen, in het vierde kwartaal van 2002 is het percentage bedrijven dat om deze reden werknemers ziet vertrekken toegenomen tot $45 \%$. Het aantal technici dat met (vervroegd) pensioen gaat, is gestegen van 350 in het eerste kwartaal tot 800 in het vierde kwartaal van 2002. Deze cijfers lijken erop te wijzen dat de vergrijzing van het personeelsbestand tot een steeds groter personeelsverloop in de Metalektro zal leiden.

Tabel 2.12

Verwachting van het percentage technische werknemers dat binnen vijf jaar met (vervroegd) pensioen zal gaan, naar bedrijfsomvang

\begin{tabular}{lcccc}
\hline Verwachting & $\begin{array}{c}0-100 \\
\text { medewerkers } \\
\%\end{array}$ & $\begin{array}{c}100-250 \\
\text { medewerkers } \\
\%\end{array}$ & $\begin{array}{c}\text { Meer dan 250 } \\
\text { medewerkers } \\
\%\end{array}$ & $\begin{array}{c}\text { Totaal } \\
\%\end{array}$ \\
\hline $5 \%$ technici of minder & 66 & 60 & 33 & 53 \\
$6 \%-10 \%$ technici & 22 & 25 & 38 & 28 \\
$11 \%-15 \%$ technici & 9 & 8 & 8 & 8 \\
$16 \%-20 \%$ technici & 1 & 8 & 8 & 3 \\
Meer dan 20\% technici & 2 & 0 & 8 & 9 \\
\hline
\end{tabular}

Bron: ROA/Werkgeverspanel Metalektro 2002

Wat zijn nu de verwachtingen voor de komende jaren bij de bedrijven zelf? Tabel 2.12 laat zien dat iets meer dan de helft van de bedrijven verwacht dat minder dan $5 \%$ van hun technisch personeel binnen vijf jaar met (vervroegd) pensioen zal gaan. Kennelijk heeft de vergrijzingsgolf deze bedrijven nog niet bereikt. Ruim een kwart 
van bedrijven in de Metalektro denkt dat $6 \%$ tot $10 \%$ van hun technici binnen vijf jaar met pensioen zal gaan. In de rest van de bedrijven speelt de vergrijzing een veel grotere rol. Zo verwacht $8 \%$ van de bedrijven dat 11 tot $15 \%$ van het technisch personeel met pensioen zal gaan. In $3 \%$ van de bedrijven vormt de vergrijzing echt een groot probleem, aangezien deze bedrijven verwachten dat maar liefst meer dan $20 \%$ van hun technische werknemers binnen vijf jaar met pensioen zal gaan.

Opvallend is dat de vergrijzingsproblematiek met name een rol speelt bij de grote bedrijven. Zo denkt maar liefst $8 \%$ van de bedrijven met meer dan 250 werknemers dat de komende vijf jaar meer dan $20 \%$ van hun technisch personeel met (vervroegd) pensioen zal gaan. De kleinere bedrijven zullen daarentegen veel minder met personeelsverloop vanwege pensionering te kampen hebben. Twee op de drie bedrijven met minder dan 100 werknemers verwacht dat maximaal $5 \%$ van het technisch personeel binnen vijf jaar met pensioen zal gaan. Er zijn geen grote verschillen in het verwachte personeelsverloop vanwege pensionering tussen de verschillende sectoren in de Metalektro. Ook zijn er weinig regionale verschillen, al lijkt het er wel op dat er de komende jaren meer technici in de regio Rijndelta en de regio West met pensioen zullen gaan dan in de rest van Nederland.

Figuur 2.9

Technische functies met een hoge verwachte pensioenuitstroom

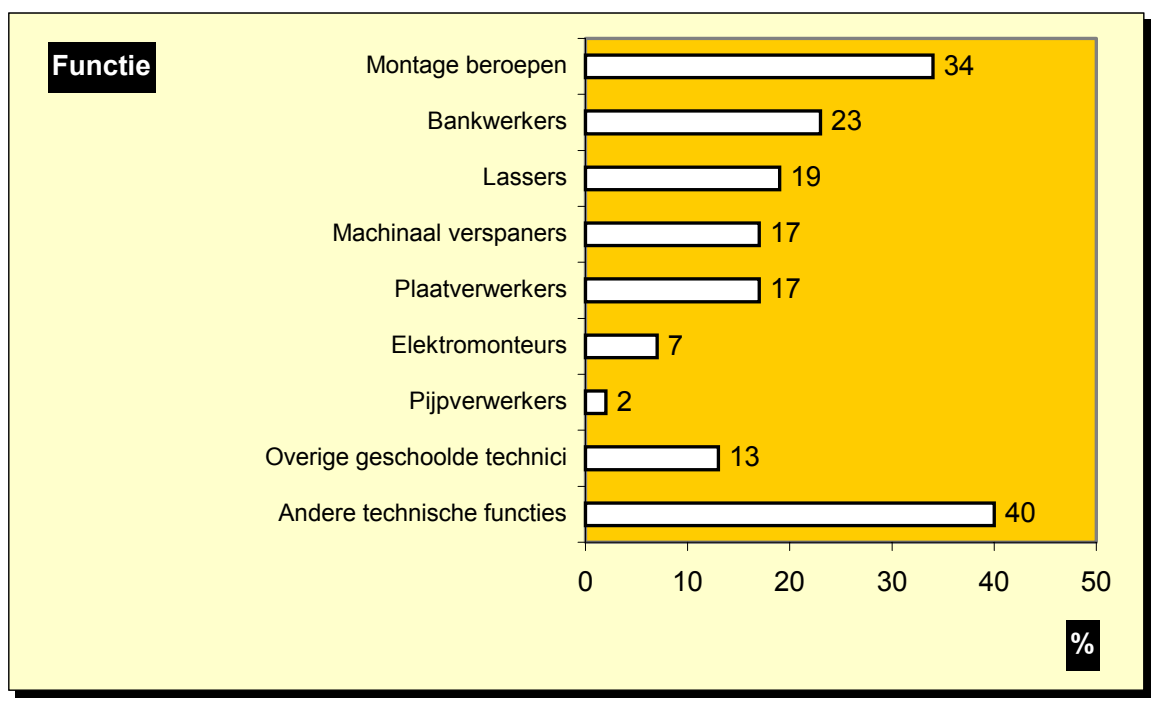

Bron: ROA/Werkgeverspanel Metalektro 2002

Figuur 2.9 laat zien dat $34 \%$ van de bedrijven denkt dat in de montageberoepen verhoudingsgewijs de meeste werknemers binnen vijf jaar met (vervroegd) pensioen gaan. Met name bedrijven die metaalproducten maken, verwachten dat veel werknemers in deze functies de komende vijf jaar met pensioen zullen gaan. Dan volgen de bankwerkers (24\%), lassers (19\%), machinaal verspaners $(17 \%)$ en plaatverwerkers $(17 \%)$. Vergeleken met bedrijven in de metaalproducten of machineindustrie, worden elektromonteurs opvallend vaak genoemd in de overige sectoren 
van de Metalektro. $40 \%$ van de bedrijven verwacht dat een hoog personeelsverloop vanwege pensionering zich de komende jaren met name zal voordoen in andere technische functies, zoals engineers en leidinggevende technici.

Wanneer bedrijven er niet in slagen de gepensioneerde technische werknemers te vervangen, kunnen er problemen ontstaan. Figuur 2.10 laat zien dat bijna de helft van de bedrijven weinig of geen problemen verwachten. Meestal wordt als reden hiervoor gegeven dat er maar weinig technici zijn die binnen vijf jaar met pensioen zullen gaan (27\%). 14\% van de bedrijven geeft aan dat de vacatures die ontstaan redelijk eenvoudig weer ingevuld kunnen worden, terwijl $6 \%$ van de bedrijven geen problemen verwacht omdat het type werkzaamheden dat de technici verrichten, die met pensioen zullen gaan, in omvang afneemt.

Het merendeel van de bedrijven blijkt echter wel degelijk knelpunten met de vervanging te verwachten. Zo denkt $27 \%$ van de bedrijven problemen te krijgen die met de nodige inspanningen wel oplosbaar zijn. Ongeveer $6 \%$ van de bedrijven verwacht daarentegen dat de problemen met de vervanging van technische werknemers die met pensioen gaan de komende jaren onoplosbaar groot zullen zijn.

Figuur 2.10

Verwachte problemen met de vervanging van technische werknemers die binnen vijf jaar met (vervroegd) pensioen zullen gaan

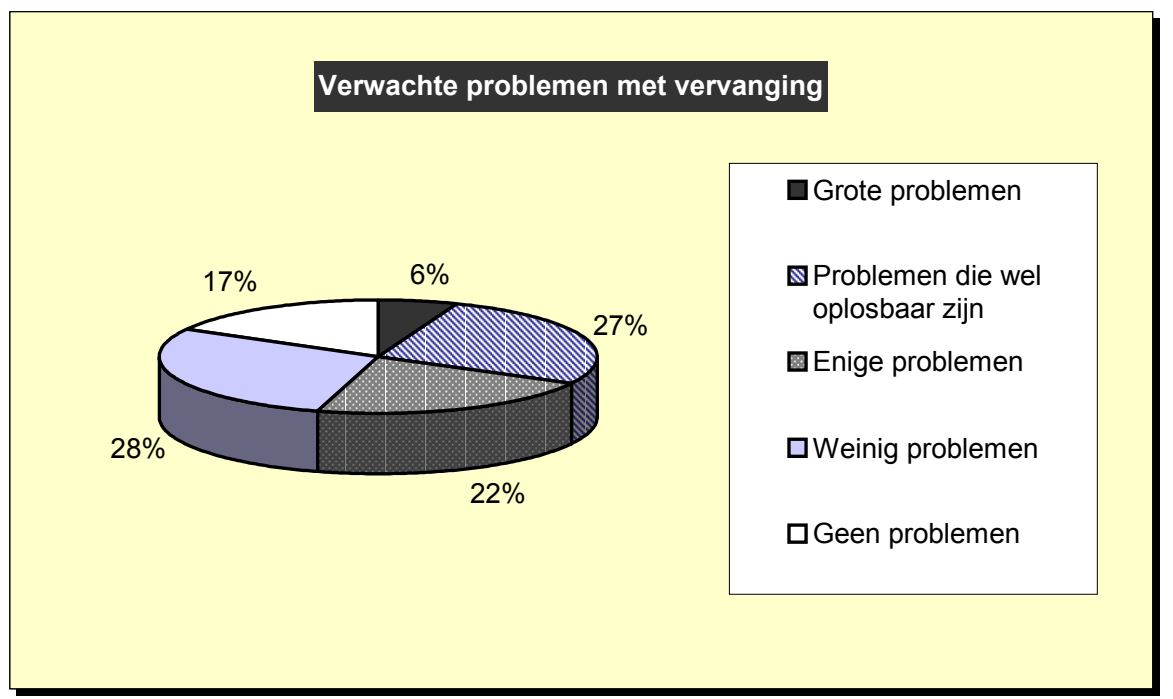

Bron: ROA/Werkgeverspanel Metalektro 2002

Opvallend is dat de grote bedrijven, die over het algemeen een hoger personeelsverloop vanwege pensionering verwachten, geen grotere problemen met de vervanging van deze werknemers verwachten dan kleine bedrijven. Wel blijkt dat de bedrijven in de regio's Rijndelta en West, waar het verwachte personeelsverloop vanwege pensionering ook hoog is, de grootste problemen verwachten. 
Figuur 2.11

Verwachte problemen met de vervanging van technische werknemers die binnen vijf jaar met (vervroegd) pensioen zullen gaan, naar functie

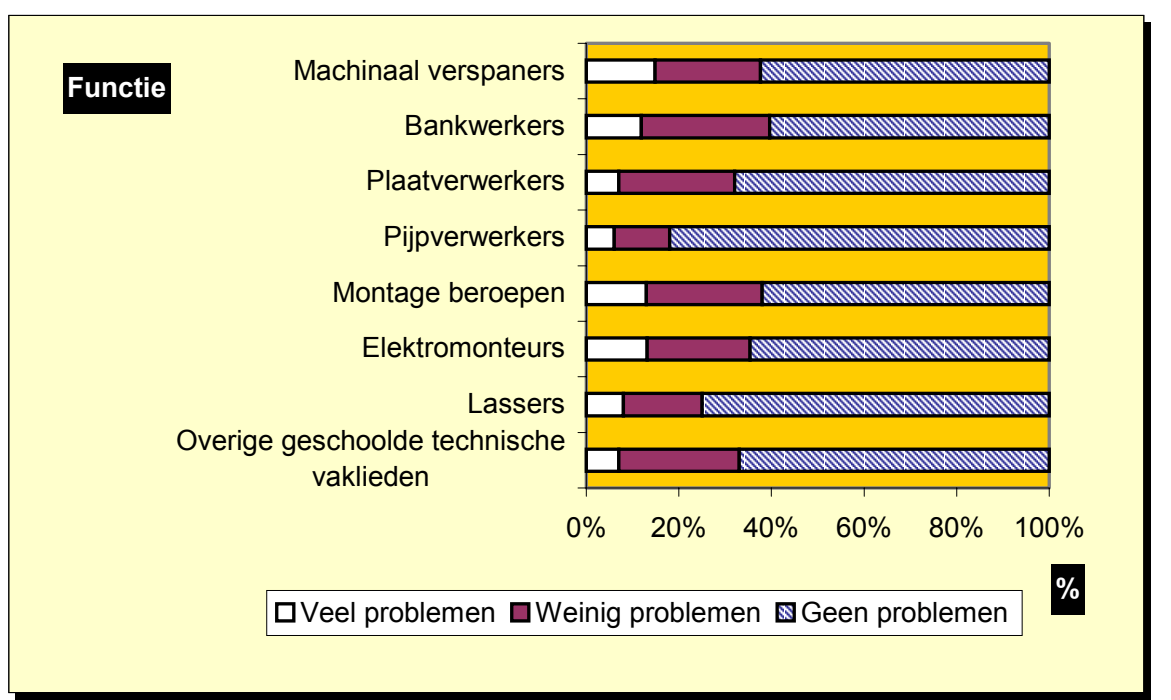

Bron: ROA/Werkgeverspanel Metalektro 2002

Figuur 2.11 laat zien dat bedrijven met name problemen verwachten bij de vervanging van machinaal verspaners, bankwerkers, en - zoals verwacht werknemers in de montageberoepen. Hoewel de groep elektromonteurs die met pensioen gaat redelijk klein is (zie figuur 2.9), zal het moeilijk zijn deze te vervangen. Immers, $13 \%$ van de bedrijven verwacht veel problemen en $22 \%$ geringe problemen bij de vervanging van deze werknemers. Opmerkelijk is verder dat de problemen met de vervanging van lassers - toch ook een groep waarin veel vergrijzing te vinden is naar verwachting zullen meevallen. Driekwart van de bedrijven verwacht geen moeilijkheden rondom de vervanging van deze werknemers. De minste problemen worden verwacht rondom de pijpverwerkers. Maar liefst $82 \%$ van de bedrijven verwacht geen problemen met de vervanging van deze werknemers wanneer zij de komende jaren met pensioen zullen gaan.

Overigens zegt $65 \%$ van de bedrijven in de Metalektro maatregelen in petto te hebben om de problemen bij de vervanging van gepensioneerde technische werknemers te beperken. Het gaat dan meestal om het aantrekken van jonge mensen om ze vervolgens in het bedrijf op te leiden, het uitbreiden en verbeteren van de contacten met scholen en het om- en bijscholen van zittend personeel. Ook worden er wel meer stagiaires aangenomen, arbeidskrachten ingeleend en eventueel werk uitbesteed. 


\section{Vacatures in de Metalektro}

\section{$3.1 \quad$ Inleiding}

In dit hoofdstuk wordt een overzicht gegeven van de vacatureproblematiek in de Metalektro in 2002. Speciale aandacht gaat hierbij uit naar de vacatures voor het technisch personeel.

Zo wordt er in paragraaf 3.2 beschreven hoeveel vacatures er per kwartaal openstaan. Er wordt nagegaan in welke functies deze vacatures zich voordoen, hoe lang ze openstaan en om welke redenen deze vacatures bij bedrijven in de Metalektro ontstaan zijn. In paragraaf 3.3 wordt ingegaan op de problemen die zich voordoen bij het opvullen van vacatures voor technisch personeel. Ook de gevolgen die bedrijven in de Metalektro ondervinden wanneer vacatures niet opgevuld kunnen worden, komen in deze paragraaf aan bod. Paragraaf 3.4 ten slotte blikt naar de toekomst. Hoe zien bedrijven de vacatureproblematiek in 2003? Verwachten zij meer of minder problemen te ondervinden met het aantrekken van voldoende en/of geschikt technisch personeel en waarom?

\subsection{Vacatures in de Metalektro}

leder kwartaal is aan de bedrijven in het werkgeverspanel Metalektro gevraagd aan te geven hoeveel vacatures er bij hen openstaan. Figuur 3.1 laat zien dat de meeste vacatures in 2002 betrekking hebben op functies voor uitvoerende technici. Gezien het feit dat deze beroepscategorie $63 \%$ van alle werknemers in de Metalektro uitmaakt, is dit ook niet vreemd. Het aantal vacatures voor uitvoerende technische functies is met name in de eerste twee kwartalen van 2002 hoog (rond de 2.800), maar neemt daarna af naar minder dan 2.000 vacatures in het vierde kwartaal. Bijna hetzelfde patroon geldt voor de ondersteunende functies, al neemt het aantal vacatures in het vierde kwartaal van 2002 weer toe. Het aantal vacatures voor leidinggevende technische functies schommelt rond de 300 à 400 . Ook het aantal vacatures voor managementfuncties verandert in de loop van 2002 niet veel: het zijn er ongeveer 150. Alleen in het derde kwartaal is een flinke daling te zien; toen stonden slechts 70 vacatures voor managementfuncties in de Metalektro open.

In totaal stonden er in het eerste kwartaal van 2002 ruim 4.500 vacatures in de Metalektro open. In het tweede kwartaal steeg dit aantal tot ruim 5.000. In het derde en vierde kwartaal van 2002 waren er beduidend minder vacatures: respectievelijk zo'n 3.200 en 3.450. Ondanks de minder rooskleurige economische situatie staan er echter nog heel wat vacatures in de Metalektro open, met name voor technici. 
Figuur 3.1

Aantal vacatures per kwartaal in 2002, naar beroepscategorie

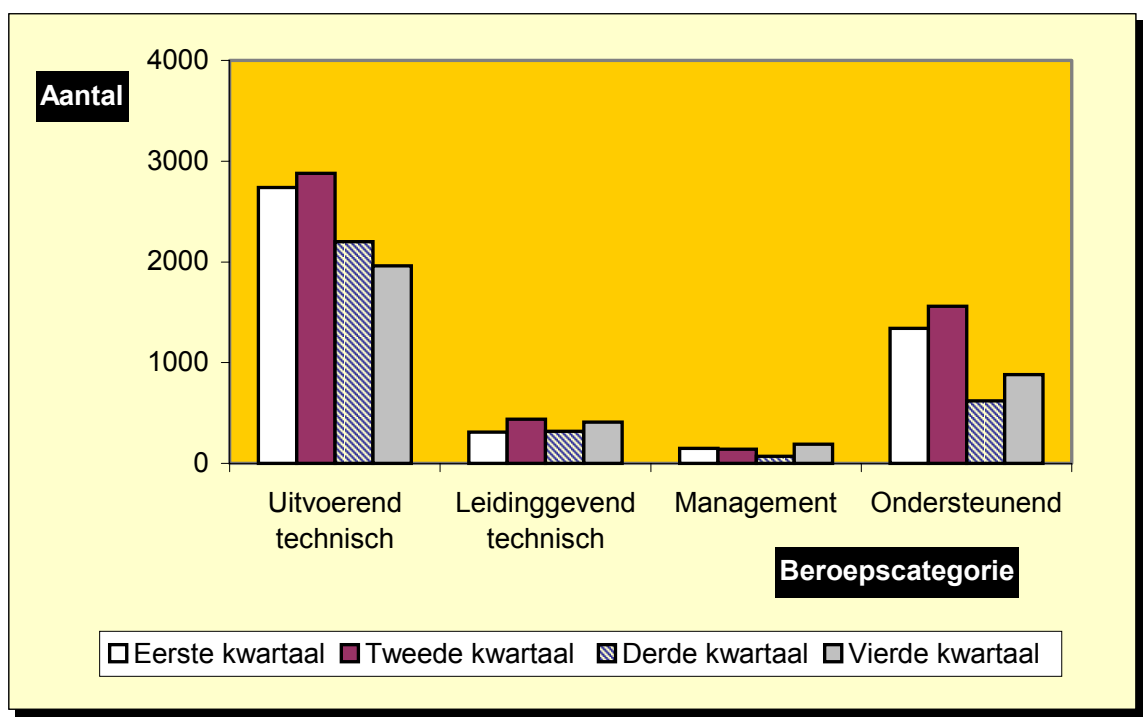

Bron: ROA/Werkgeverspanel Metalektro 2002

Tabel 3.1 geeft dan ook aan dat een ruime meerderheid (zo'n 60 tot 65\%) van de bedrijven met vacatures te kampen heeft. In het tweede kwartaal van 2002 had zelfs $73 \%$ van de bedrijven in de Metalektro vacatures openstaan. Het gemiddelde aantal vacatures per bedrijf ligt in de laatste twee kwartalen van 2002 beduidend lager dan in de eerste twee kwartalen: 2,7 tegenover 4 à 5 in de eerste helft van 2002. Opvallend hierbij is dat deze daling in het gemiddelde aantal vacatures met name geldt voor de ondersteunende functies, zoals secretaresses, administratief personeel, schoonmakers en in- en verkopers. De minder rooskleurige situatie op de afzetmarkten zou hier debet aan kunnen zijn: in tijden van economische teruggang zijn er minder vacatures voor deze ondersteunende functies. Het gemiddeld aantal vacatures voor leidinggevende technische functies en managementfuncties is daarentegen in de loop der 2002 ongeveer gelijk gebleven.

Tabel 3.1

Bedrijven met vacatures per kwartaal in 2002, naar beroepscategorie*

\begin{tabular}{lcccc}
\hline Beroepscategorie & $\begin{array}{c}\text { Eerste } \\
\text { kwartaal } \\
\%\end{array}$ & $\begin{array}{c}\text { Tweede } \\
\text { kwartaal } \\
\%\end{array}$ & $\begin{array}{c}\text { Derde } \\
\text { kwartaal } \\
\%\end{array}$ & $\begin{array}{c}\text { Vierde } \\
\text { kwartaal } \\
\%\end{array}$ \\
\hline Uitvoerende technische functies & 36 & 47 & 38 & 30 \\
Leidinggevende technische functies & 10 & 19 & 11 & 13 \\
Management functies & 8 & 9 & 5 & 11 \\
Ondersteunende functies & 32 & 44 & 28 & 38 \\
Totaal & 59 & 73 & 59 & 65
\end{tabular}

${ }^{*}$ De verschillende percentages staan los van elkaar en hoeven dus niet op te tellen tot $100 \%$. Bron: ROA/Werkgeverspanel Metalektro 2002 
In de eerste drie kwartalen van 2002 blijken bedrijven in de sector metaalproducten en de machine-industrie in alle beroepscategorieën minder openstaande vacatures te hebben dan bedrijven in de overige sectoren binnen de Metalektro. In het laatste kwartaal van 2002 hebben de bedrijven in de overige sectoren daarentegen meer vacatures voor managementfuncties en ondersteunende functies, terwijl bedrijven in de machine-industrie dan meer vacatures voor uitvoerende technici hebben. Ook zijn er enkele regionale verschillen gevonden. Bedrijven in de Rijndelta hebben het hele jaar door meer vacatures openstaan voor uitvoerende en leidinggevende technische functies en voor managementfuncties dan de bedrijven in de rest van het land. Daarnaast kent de regio West meer vacatures voor leidinggevende technici in het eerste en vierde kwartaal van 2002.

Bedrijven met een hoge personeelsuitstroom kennen over het algemeen ook meer vacatures dan bedrijven met weinig vertrekkende werknemers. Dit geldt voor alle vier de onderscheiden beroepscategorieën, met uitzondering van de uitvoerende technici. Het blijkt namelijk dat bedrijven waar veel uitvoerende technische werknemers vertrekken, in de eerste drie kwartalen van 2002 niet beduidend meer vacatures voor uitvoerende technische functies hebben dan bedrijven met een laag personeelsverloop. In het vierde kwartaal blijkt er echter wel weer een samenhang tussen het aantal vertrokken uitvoerende technici en het aantal vacatures voor deze groep werknemers te bestaan. Over het algemeen kunnen we dus stellen dat bedrijven met een hoog personeelsverloop niet primair te maken hebben met een daling van de werkgelegenheid, maar dat zij er minder goed in slagen om werknemers aan hun bedrijf te binden.

Tabel 3.2

Aantal vacatures per kwartaal in 2002, naar functie

\begin{tabular}{|c|c|c|c|c|}
\hline Functie & $\begin{array}{c}\text { Eerste } \\
\text { kwartaal } \\
\text { aantal }\end{array}$ & $\begin{array}{c}\text { Tweede } \\
\text { kwartaal } \\
\text { aantal }\end{array}$ & $\begin{array}{c}\text { Derde } \\
\text { kwartaal } \\
\text { aantal }\end{array}$ & $\begin{array}{c}\text { Vierde } \\
\text { kwartaal } \\
\text { aantal }\end{array}$ \\
\hline \multicolumn{5}{|l|}{ Laag-en ongeschoold personeel } \\
\hline Laag- en ongeschoold personeel & 400 & 800 & 670 & 460 \\
\hline \multicolumn{5}{|l|}{ Uitvoerende technici op MBO niveau } \\
\hline Machinaal verspanende beroepen & 150 & 220 & 170 & 100 \\
\hline Bankwerk beroepen & 190 & 320 & 130 & 90 \\
\hline Plaatverwerkende beroepen & 80 & 170 & 140 & 70 \\
\hline Pijpverwerkende beroepen & 320 & 320 & 130 & 80 \\
\hline Montageberoepen & 390 & 600 & 1.050 & 310 \\
\hline Elektromonteurs & 270 & 290 & 290 & 520 \\
\hline Lasberoepen & 250 & 240 & 150 & 110 \\
\hline Overige geschoolde technici & 170 & 450 & 60 & 250 \\
\hline \multicolumn{5}{|c|}{$\begin{array}{l}\text { Overige technische beroepen op middelbaar } \\
\text { en hoger niveau }\end{array}$} \\
\hline Tekenaars/constructeurs & 160 & 240 & 190 & 120 \\
\hline Werkvoorbereiders & 70 & 130 & 110 & 80 \\
\hline Automatiseringspersoneel / IT'ers & - & 50 & 30 & 30 \\
\hline Overig & 440 & 380 & 320 & 280 \\
\hline
\end{tabular}

- Geen gegevens beschikbaar.

Bron: ROA/Werkgeverspanel Metalektro 2002 
Voor welke technische functies in de Metalektro stonden er in 2002 vooral vacatures open? Tabel 3.2 laat zien dat er in 2002 een grote behoefte was aan uitvoerende technici op MBO niveau. Met name voor werknemers in de montageberoepen en elektromonteurs zijn er veel vacatures. Bij de elektromonteurs is er overigens in het vierde kwartaal van 2002 een opmerkelijke stijging in het aantal vacatures te zien. De behoefte aan nieuw laag- en ongeschoold personeel daalt daarentegen in het vierde kwartaal naar zo'n 460 vacatures. Dit lijkt erop te wijzen dat er in de Metalektro steeds minder vraag is naar laaggeschoolde arbeid als gevolg van de upgrading van de kwalificatie-eisen (zie hoofdstuk 6), vanwege technologische en organisatorische vernieuwingen van het productieproces, of omdat bedrijven dit soort werkzaamheden uitbesteden naar lagelonenlanden, en zich in Nederland concentreren op gespecialiseerde, hooggekwalificeerde taken met een hoge toegevoegde waarde.

Grote bedrijven hebben over het algemeen meer vacatures voor technisch personeel openstaan, vooral voor uitvoerende technici op MBO niveau, dan kleine bedrijven. Vergeleken met bedrijven in de sectoren metaalproducten en machine-industrie, kennen bedrijven in de overige sectoren ook meer vacatures voor uitvoerende technici, met name in de eerste twee kwartalen van 2002.

\section{Duur van openstaande vacatures}

Tabel 3.3 laat zien dat het grootste deel van de vacatures in de Metalektro korter dan 3 maanden openstaat. In het tweede kwartaal ging het hierbij om bijna de helft van alle technische vacatures, in het derde kwartaal van 2002 om maar liefst $70 \%$ van de vacatures. De rest van de openstaande vacatures is volgens de gangbare definitie als moeilijk vervulbaar te kwalificeren. Met uitzondering van het derde kwartaal stond in 2002 één op de tien vacatures voor technisch personeel zelfs langer dan één jaar open.

Tabel 3.3

Duur van openstaande vacatures voor technische werknemers per kwartaal in 2002

\begin{tabular}{lcccc}
\hline & $\begin{array}{c}\text { Eerste } \\
\text { kwartaal } \\
\%\end{array}$ & $\begin{array}{c}\text { Tweede } \\
\text { kwartaal } \\
\%\end{array}$ & $\begin{array}{c}\text { Derde } \\
\text { kwartaal } \\
\%\end{array}$ & $\begin{array}{c}\text { Vierde } \\
\text { kwartaal } \\
\%\end{array}$ \\
\hline Korter dan 3 maanden & 60 & 49 & 70 & 58 \\
$3-6$ maanden & $31 *$ & 27 & 22 & 25 \\
$6-12$ maanden & - & 14 & 7 & 9 \\
Langer dan 12 maanden & 9 & 10 & 1 & 9 \\
* In het eerste kwartaal is er geen onderscheid gemaakt tussen vacatures die 3-6 maanden \\
$\quad \begin{array}{l}\text { openstaan en vacatures die 6 - 12 maanden openstaan. } \\
\quad \text { Geen gegevens beschikbaar. }\end{array}$ \\
Bron: ROAMerkgeverspanel Metalektro 2002
\end{tabular}

Het is opmerkelijk dat de kleine bedrijven vaker met moeilijk vervulbare vacatures worden geconfronteerd dan grote bedrijven. Grote bedrijven mogen dan wel meer vacatures voor technisch personeel hebben, ze blijken ze wel sneller te kunnen vervullen. Tussen sectoren blijken geen significante verschillen te zijn in de duur van 
de openstaande vacatures. Ook zijn er op dit punt geen duidelijke regionale verschillen, al lijkt het er wel op dat de regio Rijndelta in het tweede kwartaal van 2002 meer moeilijk vervulbare vacatures kende dan de rest van Nederland.

\section{Ontstaan van vacatures}

Vacatures kunnen om twee redenen ontstaan. Of er is sprake van een uitbreidingsvraag, dat wil zeggen een groei van de werkgelegenheid. Of er is sprake van een vervangingsvraag, vanwege het vertrek van personeel door pensionering, arbeidsongeschiktheid, (tijdelijke of gedeeltelijke) terugtrekking van de arbeidsmarkt en personeelsverloop naar andere bedrijven of sectoren.

Figuur 3.2

Reden van ontstaan van vacatures voor technische werknemers in het eerste kwartaal van 2002

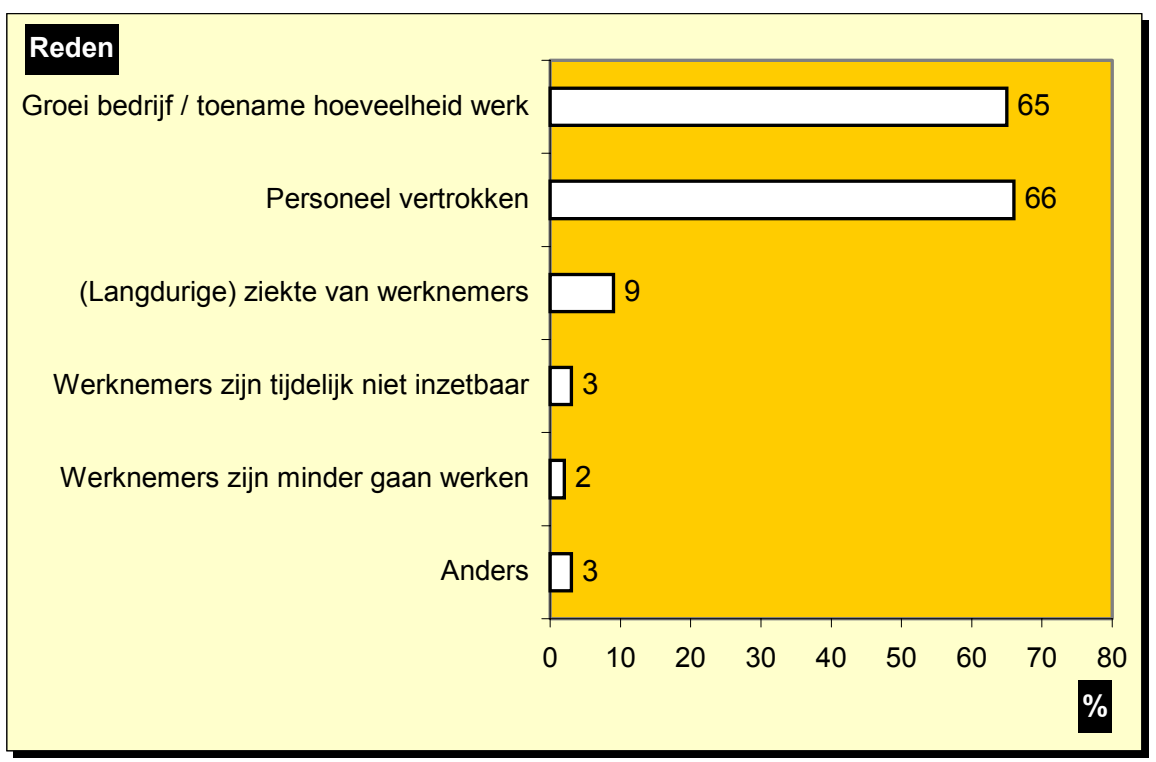

Bron: ROA/Werkgeverspanel Metalektro 2002

Figuur 3.2 laat zien dat $65 \%$ van de bedrijven in de Metalektro in het eerste kwartaal van 2002 vacatures voor het technisch personeel had vanwege de uitbreidingsvraag. Deze bedrijven geven aan dat de reden van de technische vacature(s) lag in de groei van hun bedrijf en/of in de toename van de hoeveelheid werk. Daarnaast heeft $66 \%$ van de bedrijven vacatures openstaan doordat er personeel vertrokken is. Bijna één op de tien bedrijven meldt dat (langdurige) ziekte van werknemers voor vacatures gezorgd heeft. In $3 \%$ van de bedrijven zijn werknemers tijdelijk niet inzetbaar en in $2 \%$ zijn ze minder gaan werken, hetgeen tot vacature(s) voor technisch personeel geleid heeft. 


\subsection{Problemen bij het vervullen van vacatures}

In het eerste kwartaal van 2002 is ook aan de bedrijven gevraagd of zij problemen hebben bij het vinden van voldoende en/of geschikt technisch personeel. Tabel 3.4 laat zien dat ongeveer eenvijfde van de bedrijven in de Metalektro aangeeft veel tot erg veel problemen te ondervinden bij het aantrekken van werknemers die men graag wil hebben. $22 \%$ van de bedrijven meldt gemiddelde problemen te hebben. Daar staat tegenover dat één op de drie bedrijven (erg) weinig problemen heeft bij het vinden van technisch personeel, terwijl nog eens $27 \%$ van de bedrijven helemaal geen problemen ondervindt. Opmerkelijk genoeg zijn er op dit punt geen verschillen tussen grote en kleine bedrijven. Kennelijk ervaren veel kleine bedrijven het grotere aantal vacatures dat langer dan 3 maanden openstaat als een gegeven. Daarnaast zijn er ook geen regionale verschillen of verschillen tussen bedrijven uit de verschillende sectoren in de Metalektro.

Tabel 3.4

Beoordeling van het ondervinden van problemen bij het vinden van voldoende en/of geschikt technisch personeel in het eerste kwartaal van 2002

\begin{tabular}{lr}
\hline Beoordeling & $\%$ \\
\hline Erg veel problemen & 5 \\
Veel problemen & 14 \\
Gemiddelde problemen & 22 \\
Weinig problemen & 24 \\
Erg weinig problemen & 9 \\
Geen problemen & 27
\end{tabular}

Bron: ROA/Werkgeverspanel Metalektro 2002

Wat zijn nu de belangrijkste problemen die bedrijven in de Metalektro ondervinden bij het aantrekken van personeel? Uit figuur 3.3 blijkt dat bijna $80 \%$ van bedrijven die problemen ondervinden bij het aantrekken van technisch personeel aangeeft dat er te weinig aanbod is van technici met de juiste kwalificaties. Bijna de helft van de bedrijven vindt dit zelfs het belangrijkste probleem bij het vinden van voldoende en/of geschikt technisch personeel. $62 \%$ van de bedrijven noemt het ontoereikende aanbod van technici met voldoende werkervaring. Bijna de helft van de bedrijven zegt problemen te ondervinden doordat er te weinig aanbod is vanuit de opleidingen. Andere belangrijke problemen zijn de te hoge salariseisen van sollicitanten (36\%) en de te hoge andere eisen die zij stellen, zoals bijvoorbeeld het flexibel willen werken (10\%). Ten slotte noemt bijna één op de vijf bedrijven de concurrentie van andere bedrijven in de Metalektro een belangrijk probleem en één op de tien de concurrentie van bedrijven buiten de Metalektro. Op de concurrentiepositie van bedrijven in de Metalektro bij de werving van technici komen we in hoofdstuk 5 nog terug. 
Figuur 3.3

Belangrijkste problemen bij het vervullen van openstaande vacatures voor technische werknemers in het eerste kwartaal van 2002 volgens bedrijven met problemen

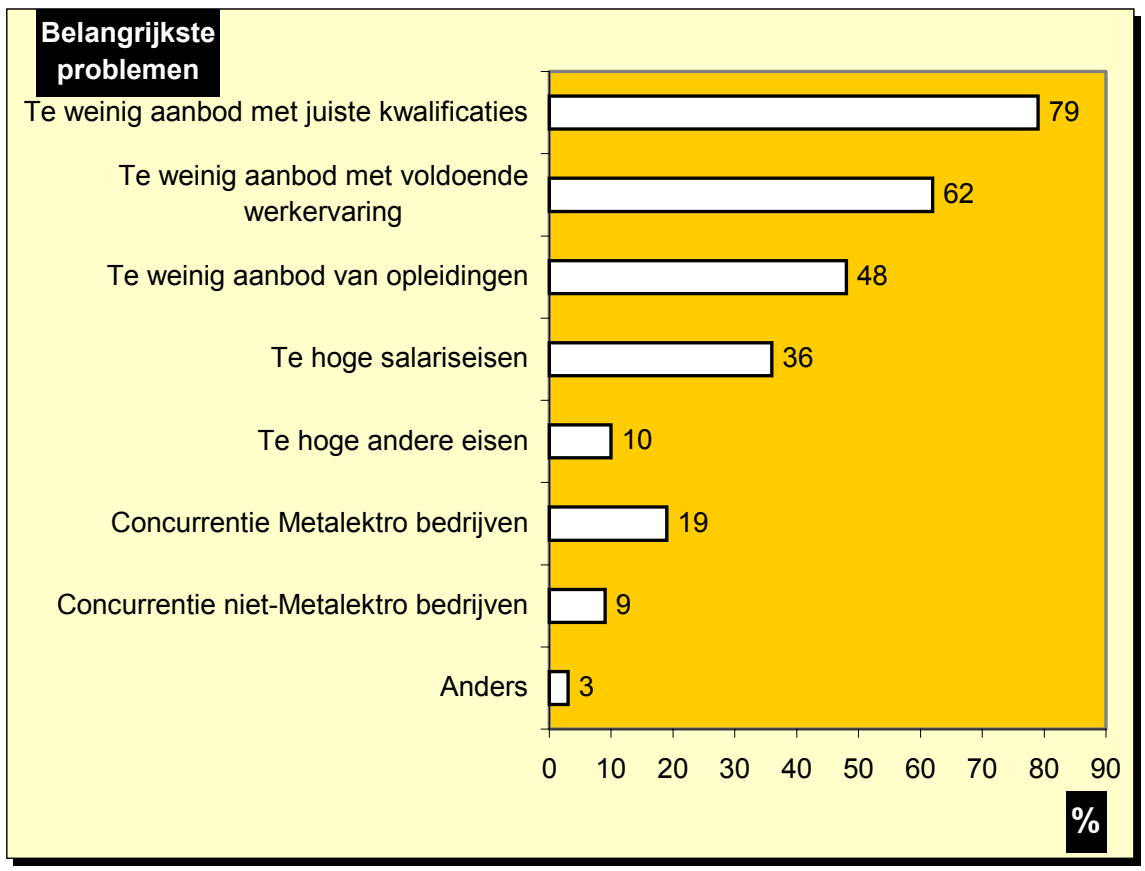

Bron: ROA/Werkgeverspanel Metalektro 2002

Tabel 3.5

Gevolgen van het tekort aan technische werknemers in de Metalektro in het eerste kwartaal van 2002 volgens bedrijven met problemen*

\begin{tabular}{lc} 
Gevolg & $\%$ \\
\hline Toegenomen werkdruk & 75 \\
Werk blijft liggen / deadlines gemist & 45 \\
Hogere wervings- of opleidingskosten & 37 \\
Verlies aan orders & 18 \\
Slechtere concurrentiepositie binnen Metalektro & 11 \\
Anders & 3
\end{tabular}

${ }^{*}$ De verschillende percentages staan los van elkaar en hoeven dus niet op te tellen tot $100 \%$. Bron: ROA/Werkgeverspanel Metalektro 2002

Ook is er nagegaan wat de daadwerkelijke gevolgen zijn van het tekort aan technische werknemers voor bedrijven in de Metalektro. Tabel 3.5 laat zien dat driekwart van de bedrijven met problemen aangeeft dat door het tekort aan technici in het eerste kwartaal van 2002 de werkdruk in hun bedrijf toegenomen is, terwijl 45\% aangeeft dat er werk is blijven liggen en dat deadlines gemist zijn. Bij $18 \%$ van de bedrijven was er zelfs sprake van een verlies aan orders. Ten slotte geeft $37 \%$ van de bedrijven met problemen bij het vinden van technisch personeel aan dat dit geleid heeft tot hogere wervings- en opleidingskosten. Al met al geen geringe gevolgen 
voor de bedrijven die met een tekort aan technici kampen. Dit beklemtoont de ernst van de personeelsproblematiek in de Metalektro.

\subsection{Verwachte vacatures in 2003}

Welke verwachtingen hebben bedrijven in de Metalektro met betrekking tot de ontwikkeling van de vacatureproblematiek in 2003? Tabel 3.6 geeft aan dat de helft van de bedrijven in het eerste kwartaal van 2002 meent dat het aantal vacatures ongeveer gelijk blijft. Eén op de vijf bedrijven verwacht zelfs een toename van het aantal vacatures in 2003. Dit betekent dat er ondanks de minder rooskleurige economische situatie nog steeds behoefte is aan nieuwe werknemers. Daar staat tegenover dat men in $31 \%$ van de bedrijven een afname van het aantal vacatures verwacht.

Tabel 3.6

Verwachting van het aantal vacatures voor 2003

\begin{tabular}{lr}
\hline Verwachting & $\%$ \\
\hline Aantal vacatures wordt veel groter & 4 \\
Aantal vacatures wordt iets groter & 16 \\
Aantal vacatures blijft ongeveer gelijk & 50 \\
Aantal vacatures wordt iets kleiner & 27 \\
Aantal vacatures wordt veel kleiner & 4 \\
\hline
\end{tabular}

Bron: ROA/Werkgeverspanel Metalektro 2002

Grote en kleine bedrijven blijken niet van elkaar te verschillen in de verwachtingen die zij hebben over het aantal vacatures in 2003. Ook zijn er geen duidelijke verschillen tussen de sectoren binnen de Metalektro. Regionale verschillen in de verwachte ontwikkeling van het aantal vacatures zijn er wel. Bedrijven in de Rijndelta melden wat vaker dat zij een toename van het aantal vacatures verwachten, terwijl bedrijven in de regio's Noord en West vaker een afname in het aantal vacatures verwachten.

Van de bedrijven in de Metalektro die een groei in het aantal vacatures verwachten, noemt iets meer dan een kwart dat dit hoofdzakelijk vanwege de vervanging van vertrokken personeel is. Ruim de helft van deze bedrijven verwacht echter een toename in het aantal vacatures vanwege een uitbreiding van de werkgelegenheid. De resterende $19 \%$ van de bedrijven noemt zowel vervanging als uitbreiding als reden waarom zij voor 2003 een toename in het aantal openstaande vacatures verwachten.

Voor welke beroepscategorie geldt de verwachte groei van het aantal vacatures nu het meest? De linker grafiek van figuur 3.4 laat zien dat bijna $60 \%$ van de bedrijven, die in 2003 een toename van het aantal vacatures verwachten, denkt dat deze toename het grootst is bij de uitvoerende technische functies. $22 \%$ van de bedrijven verwacht dat vooral het aantal vacatures voor leidinggevende technici zal toenemen. 
Daarentegen is de verwachte groei in het aantal vacatures voor de ondersteunende functies en de managementfuncties veel minder groot.

Figuur 3.4

Beroepscategorie waarvoor de in 2003 verwachte groei/krimp in het aantal vacatures het grootst is.
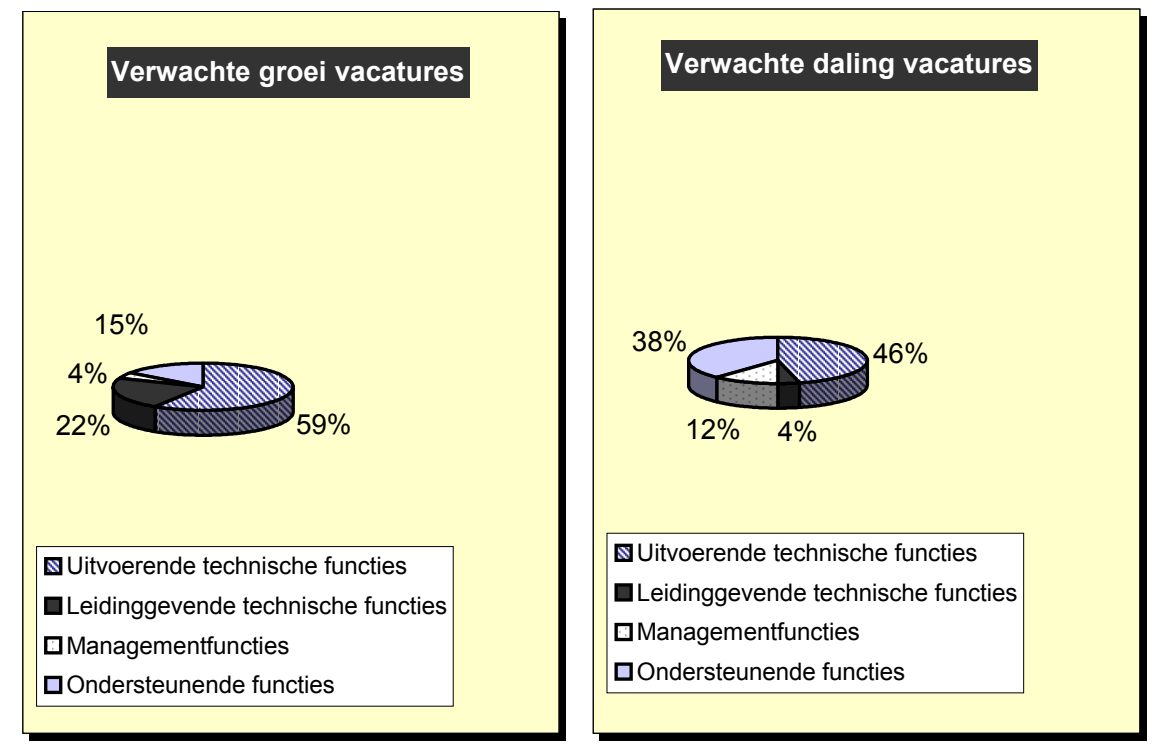

Bron: ROA/Werkgeverspanel Metalektro 2002

$17 \%$ van de bedrijven in de Metalektro gaf aan een afname van het aantal vacatures in 2003 te verwachten. De rechter grarfiek van figuur 3.4 laat zien dat $46 \%$ van deze bedrijven denkt dat deze daling het grootst is bij de uitvoerende technici. Opmerkelijk is echter dat de bedrijven die een afname in het aantal vacatures verwachten, ook relatief vaak de ondersteunende functies als secretaresses, boekhouders, schoonmakers en inkoop-verkoop personeel (38\%) en de managementfuncties (12\%) noemen. Blijkbaar zijn bedrijven in de huidige recessie erop gericht hun personeelsbestand vooral in deze 'overhead' beroepen te beperken.

\section{Verwachte problemen in 2003}

Naast een verwachting van het aantal vacatures voor 2003 , is aan de bedrijven in de Metalektro ook gevraagd een verwachting te geven van de problemen die zij zullen ondervinden bij het vinden van voldoende en/of geschikt technisch personeel. Uit tabel 3.7 blijkt dat $23 \%$ van de bedrijven meent dat deze problemen in 2003 zullen toenemen, terwijl ongeveer eenderde van de bedrijven verwacht dat de problemen gelijk zullen blijven. $14 \%$ van de bedrijven denkt echter dat de problemen met het vinden van technici zullen afnemen, terwijl 13\% helemaal geen problemen verwacht. 
Tabel 3.7

Verwachte problemen met het vinden van voldoende en/of geschikt technisch personeel in 2003

Verwachting

Problemen nemen toe

Problemen blijven gelijk

Problemen nemen af

Geen problemen

Geen idee / geen mening

Bron: ROA/Werkgeverspanel Metalektro 2002

Er zijn geen opmerkelijke verschillen in de verwachte problematiek bij het vinden van technisch personeel tussen grote en kleine bedrijven. Ook zijn er geen verschillen tussen bedrijven uit de verschillende sectoren binnen de Metalektro. Wel is er sprake van enkele regionale verschillen. Bedrijven in de regio's Rijndelta en West verwachten in 2003 vaker dat de problemen met het aantrekken van technici groter zullen worden, terwijl bedrijven in de regio Zuidoost vaker aangeven dat deze problemen juist zullen afnemen.

\section{Figuur 3.5}

Oorzaak van toenemende problemen bij het vinden van voldoende en/of geschikte technische werknemers volgens bedrijven met toenemende problemen

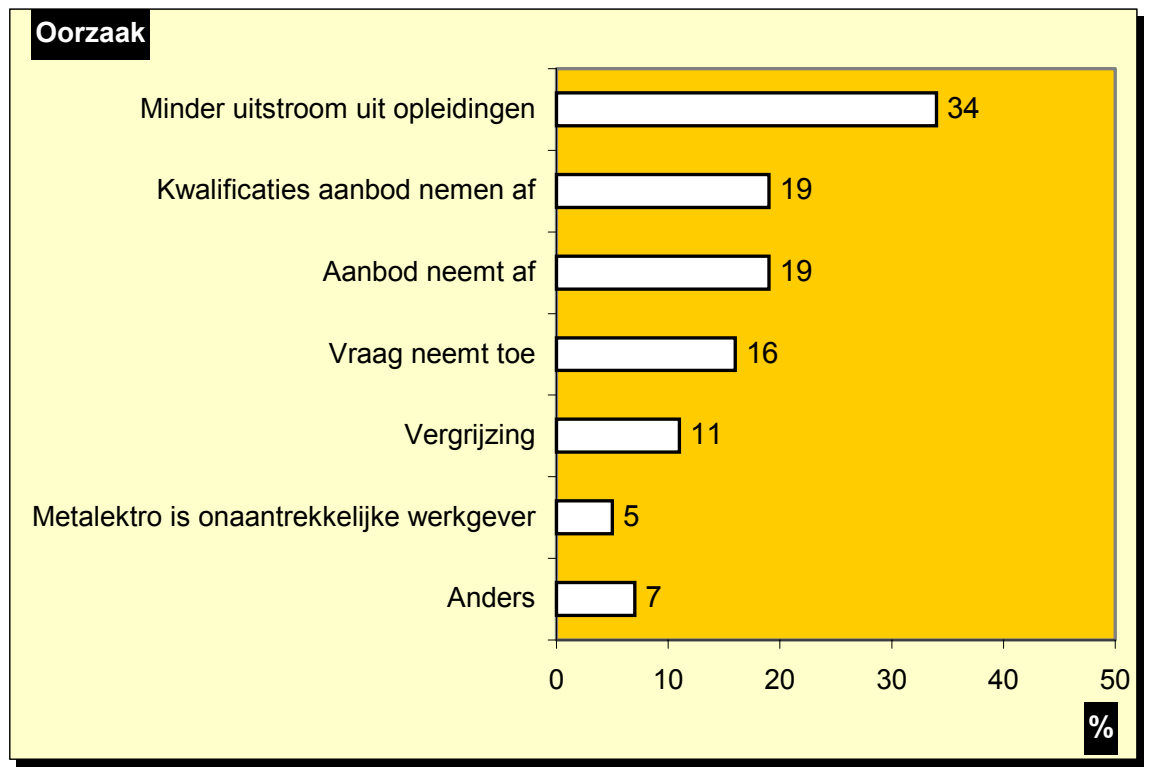

Bron: ROA/Werkgeverspanel Metalektro 2002

Van de bedrijven die verwachten dat de problemen bij het vinden van voldoende en/of geschikt technisch personeel in 2003 zullen toenemen, legt ongeveer één op de drie de reden hiervan bij de kleinere uitstroom van gediplomeerde schoolverlaters uit de technische opleidingen (zie figuur 3.5). Bijna $20 \%$ van de bedrijven meent dat het afnemen van de kwalificaties van het aanbod aan technici de oorzaak zijn van de 
toenemende problemen. Nog eens $20 \%$ noemt het afnemende aanbod van technische werknemers an sich. Andere oorzaken die genoemd worden zijn een toenemende vraag $(16 \%)$, de vergrijzing $(11 \%)$ en het feit dat de Metalektro als een onaantrekkelijke werkgever gezien wordt $(5 \%)$.

Ook aan de bedrijven die een afname van de personeelsproblemen in 2003 verwachten is gevraagd naar de reden van deze toekomstige afname. Twee op de vijf bedrijven zegt dat de vraag naar nieuwe technische werknemers bij hun bedrijf zal afnemen, waardoor de problemen in 2003 minder groot zullen zijn. Daarentegen verwacht $58 \%$ van de bedrijven dat het grotere aanbod aan technici de problemen zal verminderen. Aangenomen mag worden dat deze bedrijven denken dat dit toenemende aanbod vooral betrekking heeft op technisch personeel dat bij andere bedrijven overtollig wordt. 



\section{De verwachte arbeidsmarktontwikkeling in de Metalektro tot 2006}

\subsection{Inleiding}

In hoofdstuk 3 werd reeds ingegaan op de verwachte vacatureontwikkelingen in 2003. Om een goed beeld te schetsen van de ontwikkelingen op de wat langere termijn zal in dit hoofdstuk worden ingegaan op de verwachte toekomstige arbeidsmarktsituatie voor de Metalektro op de middellange termijn. Informatie over de verwachte toekomstige tekorten en overschotten van personeel is van groot belang voor de bedrijven in de Metalektro omdat het de mogelijkheid biedt om het te voeren wervings- en personeelsbeleid beter vorm te geven.

Dit hoofdstuk is als volgt opgebouwd. In paragraaf 4.2 wordt in het kort uitgelegd hoe de arbeidsmarktprognoses van het ROA tot stand zijn gekomen. In paragraaf 4.3 worden arbeidsmarktprognoses gepresenteerd per sector, beroep en opleiding (zie bijlage $B$ voor de gebruikte classificaties). De beschrijvingen in deze paragraaf spitsen zich toe op de belangrijkste beroepen en opleidingen binnen de Metalektro die ook al in hoofdstuk 1 aan de orde kwamen. Tenslotte wordt er in paragraaf 4.4 ingegaan op de vraag in hoeverre individuele bedrijven in de Metalektro de prognoses onderschrijven.

\subsection{Prognosemethodiek}

De arbeidsmarktprognoses tot 2006 vormen een totaal overzicht van zowel vraag en aanbod op de arbeidsmarkt. De in dit rapport opgenomen prognoses zijn gebaseerd op de uitkomsten zoals deze zijn gepresenteerd in De arbeidsmarkt naar opleiding en beroep tot 2006 van het ROA. ${ }^{3}$

\section{Vraagzijde van de arbeidsmarkt}

De vraag naar arbeidskrachten op de arbeidsmarkt wordt in het door het ROA gehanteerde model opgesplitst in enerzijds de uitbreidingsvraag en anderzijds de vervangingsvraag. De uitbreidingsvraag heeft betrekking op de vraag naar (nieuwe) arbeidskrachten als gevolg van economische groei. De vervangingsvraag heeft daarentegen betrekking op de vraag die het gevolg is van arbeidsmarktuitstroom van werkenden vanwege pensioen, VUT, arbeidsongeschiktheid, of het tijdelijk uittreden van de arbeidsmarkt. Alleen bij een afnemende werkgelegenheid zullen de door vertrek vrijgekomen plaatsen niet opgevuld worden.

3. Zie ROA (2001), De Arbeidsmarkt naar Opleiding en Beroep, ROA-R-2001/8, Maastricht. 
De som van de uitbreidingsvraag, mits deze positief is, en de netto vervangingvraag resulteert in de zogenaamde baanopeningen, oftewel de totale vraag naar (nieuwe) arbeidskrachten.

De in dit rapport opgenomen prognoses van de uitbreidingsvraag zijn gebaseerd op de werkgelegenheidsprognoses voor bedrijfssectoren van het Centraal Planbureau (CPB). Hierbij is uitgegaan van het zogenaamde 'Global Competition Scenario' in een lange termijnverkenning van het CPB. ${ }^{4}$ Voor de prognoses van het eerste jaar van het lange termijnscenario is aanvullend gebruik gemaakt van het Centraal Economisch Plan 2001 (CEP) van het CPB. ${ }^{5}$ Door het gebruik van deze korte termijnprognoses wordt het gehanteerde lange termijnscenario gecorrigeerd met de meest recente inzichten in de groeiverwachtingen van het CEP.

De vervangingsvraag ontstaat, zoals gezegd, doordat de arbeidsplaatsen van werkenden die met pensioen gaan, arbeidsongeschikt worden of zich (tijdelijk) terugtrekken van de arbeidsmarkt, opnieuw moeten worden opgevuld. Een andere bron van de vervangingsvraag vormt de beroepsmobiliteit: wanneer werkenden van beroep veranderen ontstaat er in het beroep dat ze verlaten een vervangingsbehoefte. Als mensen binnen een bepaalde beroepsgroep van baan veranderen wordt dit echter niet tot de vervangingsvraag gerekend. Deze mensen blijven immers binnen het beroep actief op de arbeidsmarkt. De vervangingsvraag wordt gebaseerd op instroompatronen in het verleden die met behulp van de Enquête Beroepsbevolking $(\mathrm{EBB})$ van het $\mathrm{CBS}$ berekend kunnen worden.

\section{Aanbodzijde van de arbeidsmarkt}

Tegenover de vraag naar (nieuwe) arbeidskrachten staat het aanbod van nieuwkomers op de arbeidsmarkt: de schoolverlaters. De prognoses van de verwachte arbeidsmarktinstroom van schoolverlaters tot 2006 zijn gebaseerd op gegevens van het Ministerie van Onderwijs, Cultuur en Wetenschappen. ${ }^{6}$

\section{Confrontatie vraag en aanbod: knelpunten en perspectieven}

Het tegen elkaar afzetten van de verwachte vraag naar en het verwachte aanbod van arbeidskrachten geeft een indicatie van de knelpunten in de personeelsvoorziening die werkgevers in de toekomst kunnen verwachten, en waar zij, bijvoorbeeld door het voeren van een geschikt recruterings- en personeelsbeleid, op in kunnen spelen. Daarnaast geeft de verhouding van vraag en aanbod voor schoolverlaters inzicht in de vraag wat hun toekomstperspectieven op de arbeidsmarkt zullen zijn bij het afronden van hun opleiding. Het ROA heeft voor het inschatten van de toekomstige knelpunten op de arbeidsmarkt een indicator ontwikkeld, die gebaseerd is op de

4. Zie: CPB (1997), Omgevingsscenario's Lange Termijn Verkenning 1995-2020, Werkdocument No. 89, Den Haag.

5. Zie: CPB (2001), Centraal Economisch Plan 2001, Den Haag.

6. Hierbij wordt gebruik gemaakt van de referentieramingen en de onderwijsmatrix. Deze cijfers zijn vervolgens aangevuld met prognoses van de doorstroom naar het post-initiële onderwijs. 
vraag-aanbodverhoudingen op de arbeidsmarkt. Deze Indicator Toekomstige Knelpunten in de Personeelsvoorziening (ITKP) is de verhouding tussen enerzijds de verwachte instroom op de arbeidsmarkt van schoolverlaters en het aantal direct bemiddelbare werkzoekenden en anderzijds de som van de verwachte uitbreidingsvraag en vervangingsvraag. De knelpunten in de personeelsvoorziening kunnen ook naar beroepsgroep worden verbijzonderd op basis van de Indicator Toekomstige Knelpunten in de personeelsvoorziening naar Beroep (ITKB). ${ }^{7}$

\subsection{De arbeidsmarkt voor de Metalektro tot 2006}

In deze paragraaf worden de verwachte arbeidsmarktontwikkelingen voor de Metalektrosector gepresenteerd. Op basis van de besproken methodiek komen achtereenvolgens de ontwikkelingen voor de sector als geheel, de perspectieven per beroep en de perspectieven per opleiding aan de orde.

\section{Bedrijfssector}

In tabel 4.1 staan de middellange termijn uitbreidingsvraagprognoses voor 13 bedrijfssectoren en de 5 onderliggende sectoren binnen de Metalektro. De tabel laat zien dat de werkgelegenheid in de Metalektro naar verwachting de komende jaren zal krimpen. Voor de periode 2001-2006 wordt een werkgelegenheidskrimp (een "negatieve uitbreidingsvraag") ter grootte van ruim 9.000 arbeidsplaatsen voorspeld. Deze afname van de werkgelegenheid voor de Metalektro komt neer op ongeveer $4 \%$ van de totale werkgelegenheid in de sector. De Metalektro is daarmee één van de drie bedrijfssectoren waarvoor de komende jaren een krimpende werkgelegenheid wordt verwacht.

De werkgelegenheid zal naar verwachting relatief gezien het sterkst krimpen in de sector basismetaal en de transportmiddelensector. Voor de sector metaalproducten is het beeld wat positiever, aangezien er in deze sector een bescheiden werkgelegenheidsgroei verwacht wordt.

Tezamen met de overige industriële sectoren is de Metalektro één van de meest conjunctuurgevoelige bedrijfssectoren en het mag daarom worden aangenomen dat het in negatieve zin bijstellen van macro-economische prognoses van het Centraal Planbureau met name in deze sector gevoeld zal worden.

\section{Beroepsgroepen}

De werkgelegenheidsontwikkelingen voor de verschillende bedrijfssectoren hebben vanzelfsprekend hun weerslag op de verwachte werkgelegenheid in de verschillende beroepsgroepen. We beperken ons hier tot de belangrijkste beroepen binnen de Metalektro.

7. Meer informatie over de gebruikte methoden en technieken van de arbeidsmarktprognoses is te vinden in de ROA-publicatie Methodiek van de arbeidsmarktprognoses tot 2006, ROAW-2002/4. Hierin is per arbeidsmarktaspect opgenomen welke theorieën, data, aannames en scenario's zijn gehanteerd. 
Tabel 4.1

Uitbreidingsvraag per bedrijfssector, 2001-2006

\begin{tabular}{|c|c|c|c|c|}
\hline Bedrijfssector & Aantal & $\begin{array}{c}\text { Totaal } \\
\%\end{array}$ & $\begin{array}{l}\text { Gemiddeld } \\
\text { jaarlijks \% }\end{array}$ & Typering \\
\hline Landbouw en visserij & -20.700 & -10 & $-2,1$ & erg laag \\
\hline Voeding & 6.600 & 4 & 0,8 & gemiddeld \\
\hline Chemie & -4.600 & -1 & $-0,2$ & laag \\
\hline Metalektro & -9.100 & -4 & $-0,9$ & laag \\
\hline - Basismetaal & -1.500 & -9 & $-1,9$ & laag \\
\hline - Metaalproducten & 500 & 1 & 0,2 & gemiddeld \\
\hline - Machine-industrie & -1.600 & -3 & $-0,6$ & laag \\
\hline - Elektrotechniek & -2.200 & -4 & $-0,7$ & laag \\
\hline - Transportmiddelen & -4.300 & -15 & $-3,2$ & erg laag \\
\hline Overige industrie & 5.300 & 4 & 0,8 & gemiddeld \\
\hline Energie & 900 & 2 & 0,3 & gemiddeld \\
\hline Bouw en onroerend goed & 45.200 & 9 & 1,7 & hoog \\
\hline Handel en reparatie & 80.500 & 9 & 1,6 & hoog \\
\hline Transport en communicatie & 22.200 & 5 & 1,0 & gemiddeld \\
\hline Bank- en verzekeringswezen & -5.100 & -2 & $-0,4$ & laag \\
\hline $\begin{array}{l}\text { Horeca en zakelijke } \\
\text { dienstverlening }\end{array}$ & 162.800 & 14 & 2,7 & erg hoog \\
\hline Kwartaire diensten & 77.000 & 7 & 1,3 & hoog \\
\hline Overheid en onderwijs & 53.600 & 5 & 1,1 & gemiddeld \\
\hline Totaal & 421.300 & 6 & 1,2 & - \\
\hline
\end{tabular}

Bron: CBS/CPB/ROA en CPB Memorandum 37

In tabel 4.2 staan, als percentage van de werkgelegenheid, de vraagprognoses voor de belangrijkste beroepen binnen de Metalektro. Deze prognoses hebben betrekking op de totale beroepsgroep, dat wil zeggen ook op diegenen die buiten de Metalektro in het beroep werkzaam zijn, wat als voordeel heeft dat er expliciet rekening wordt gehouden met het feit dat werknemers met bepaalde beroepen in meerdere sectoren terecht kunnen. Dit laatste is belangrijk omdat een krimpende vraag in de Metalektro niet automatisch betekent dat de vraag naar bepaalde beroepsgroepen afneemt.

Bij de meeste van de belangrijkste beroepen in de Metalektro zal de werkgelegenheid naar verwachting toenemen. Uit tabel 4.2 blijkt dat de negatieve groeiverwachting voor 2001-2006 voor de Metalektro als geheel vooral gevolgen heeft voor de uitbreidingsvraag in de beroepsgroepen assembleurs, elektromonteurs, metaalarbeiders en receptionisten en administratieve medewerkers. De negatieve uitbreidingsvraag voor receptionisten en administratieve medewerkers zal zich echter naar alle waarschijnlijkheid veel minder concentreren binnen de Metalektro dan bij de drie andere beroepen. Van alle beroepen die een groot aandeel hebben binnen de Metalektro geldt dat de productieplanners de grootste positieve uitbreidingsvraag hebben $(4,4 \%$ gemiddeld per jaar). Ook bij de boekhouders en secretaresses is er een grote uitbreidingsvraag, maar aangenomen mag worden dat deze groei zich voornamelijk zal voordoen in andere bedrijfssectoren, met name in de sectoren handel en reparatie en zakelijke dienstverlening. 
De vervangingsvraag is de belangrijkste component van de totale vraag naar arbeidskrachten voor de meeste beroepen. Dit geldt ook voor de beroepen die belangrijk zijn in de Metalektro. De vervangingsvraag is verantwoordelijk voor meer dan de helft van de baanopeningen voor alle beroepen, met uitzondering van de commercieel medewerkers (HBO niveau), de productieplanners en de systeemanalisten. De relatief lage vervangingsvraag voor deze beroepsgroepen is te verklaren door een aantal kenmerken van de werkenden. Allereerst is er weinig arbeidsmarktuittrede naar VUT of pensioen door het relatief jonge personeelsbestand. Bovendien zijn er in de drie genoemde beroepen minder belastende arbeidsomstandigheden dan in sommige technische beroepen, waardoor er minder vaak sprake is van vroegtijdige arbeidsmarktuittrede. Ten slotte geldt nog dat het aandeel van vrouwen in deze beroepen relatief gering is, wat uittrede vanwege zorgtaken reduceert. Dit laatste is echter ook van toepassing op de meeste technische beroepen in de Metalektro. In de niet-technische beroepen receptionisten en administratieve medewerkers en boekhouders en secretaresses werken daarentegen meer vrouwen. In deze beroepen is de vervangingsvraag dan ook relatief hoog.

Tabel 4.2

Uitbreidingsvraag, vervangingsvraag en baanopeningen per beroepsgroep (als gemiddeld jaarlijks percentage van de werkgelegenheid), 2001-2006

\begin{tabular}{|c|c|c|c|}
\hline Beroepsgroep & $\begin{array}{r}\text { Uitbreidings- } \\
\text { vraag } \\
\%\end{array}$ & $\begin{array}{r}\text { Vervangings- } \\
\text { vraag } \\
\%\end{array}$ & $\begin{array}{r}\text { Baan- } \\
\text { openingen } \\
\%\end{array}$ \\
\hline Productiemedewerkers & 0,7 & 2,0 & 2,7 \\
\hline Laders en lossers & 1,5 & 1,9 & 3,4 \\
\hline Metaalarbeiders & $-1,5$ & 2,9 & 2,9 \\
\hline Assembleurs & $-0,5$ & 2,5 & 2,5 \\
\hline Chauffeurs & 0,2 & 2,8 & 3,0 \\
\hline Receptionisten en administratieve medewerkers & $-2,0$ & 3,9 & 3,9 \\
\hline Installateurs & 1,0 & 2,8 & 3,8 \\
\hline Bankwerkers en lassers & 0,0 & 2,5 & 2,5 \\
\hline Monteurs & 0,1 & 2,9 & 3,0 \\
\hline Elektromonteurs & $-0,3$ & 2,5 & 2,5 \\
\hline Medisch laboranten & 1,6 & 2,3 & 3,9 \\
\hline Productieplanners & 4,4 & 1,7 & 6,1 \\
\hline Boekhouders en secretaresses & 3,1 & 3,7 & 6,8 \\
\hline Commercieel medewerkers (MBO niveau) & 0,8 & 2,9 & 3,7 \\
\hline $\begin{array}{l}\text { Werktuigbouwkundig ontwerpers en hoofden } \\
\text { technische dienst }\end{array}$ & 13 & 35 & 48 \\
\hline Systeemanalisten & $\begin{array}{l}1,3 \\
2,8\end{array}$ & $\begin{array}{l}3,0 \\
1,5\end{array}$ & $\begin{array}{l}4,0 \\
4,3\end{array}$ \\
\hline Commercieel medewerkers (HBO niveau) & 2,4 & 2,2 & 4,6 \\
\hline
\end{tabular}

Bron: CBS/CPB/ROA

De laatste kolom van tabel 4.2 geeft aan dat er voor productieplanners en boekhouders en secretaresses relatief gezien het grootste aantal baanopeningen wordt verwacht. De verwachting is dat het aantal baanopeningen voor assembleurs, bankwerkers en lassers en electromonteurs naar verhouding het kleinst zal zijn. 
De confrontatie van verwachte vraag en aanbod per beroepsgroep resulteert in de Indicator Toekomstige Knelpunten in de personeelsvoorziening naar Beroep (ITKB). In tabel 4.3 wordt voor de belangrijkste beroepen in de Metalektro de ITKB en een typering weergegeven voor de periode 2001-2006.

Tabel 4.3

Indicator Toekomstige Knelpunten in de personeelsvoorziening naar Beroep (ITKB) voor de belangrijkste beroepen binnen de Metalektro, 2001-2006

Beroepsgroep $\quad$ ITKB Typering

Productiemedewerkers

Laders en lossers

Metaalarbeiders

Assembleurs

Chauffeurs

Receptionisten en administratieve medewerkers

Installateurs

Bankwerkers en lassers

Monteurs

Elektromonteurs

Medisch laboranten

Productieplanners

Boekhouders en secretaresses

Commercieel medewerkers (MBO niveau)

Werktuigbouwkundig ontwerpers en hoofden technische dienst

Systeemanalisten

Commercieel medewerkers (HBO niveau)
0,96 vrijwel geen

0,96 vrijwel geen

0,97 vrijwel geen

0,95 groot

0,96 vrijwel geen

0,96 vrijwel geen

0,91 groot

0,92 groot

0,92 groot

0,93 groot

0,89 groot

0,95 enige

0,94 groot

0,94 groot

0,91 groot

0,88 zeer groot

0,93 groot

\section{Bron: ROA}

Het is opmerkelijk dat er, ondanks de naar verwachting beperkte werkgelegenheidsgroei, voor het merendeel van de beroepen grote knelpunten in de personeelsvoorziening worden verwacht. Alleen in de beroepsgroep chauffeurs, laders en lossers, metaalarbeiders, productiemedewerkers, en receptionisten worden er vrijwel geen knelpunten in de personeelsvoorziening verwacht.

\section{Opleidingstypen}

In tabel 4.4 staan, als percentage van de werkgelegenheid, de vraag- en aanbodprognoses voor de belangrijkste opleidingsachtergronden van de werkenden in de Metalektro. Deze verwachtingen hebben betrekking op de opleidingen als geheel, dat wil zeggen: ze hebben ook betrekking op diegenen die buiten de Metalektro met deze opleidingsachtergrond werkzaam zijn.

Het valt op dat de werkgelegenheid voor de meeste lagere opleidingsniveaus naar verwachting zal krimpen. Alleen voor personeel met een opleiding VMBO theorie (de vroegere MAVO) is er sprake van een bescheiden uitbreidingsvraag. De uitbreidingsvraag is daarentegen het hoogst voor personeel met een opleiding MBO motorvoertuigentechniek of $\mathrm{HBO}$ bedrijfskunde. 
Tabel 4.4

Uitbreidingsvraag, vervangingsvraag, baanopeningen en instroom van schoolverlaters per opleidingstype (als gemiddeld jaarlijks percentage van de werkgelegenheid), 2001-2006

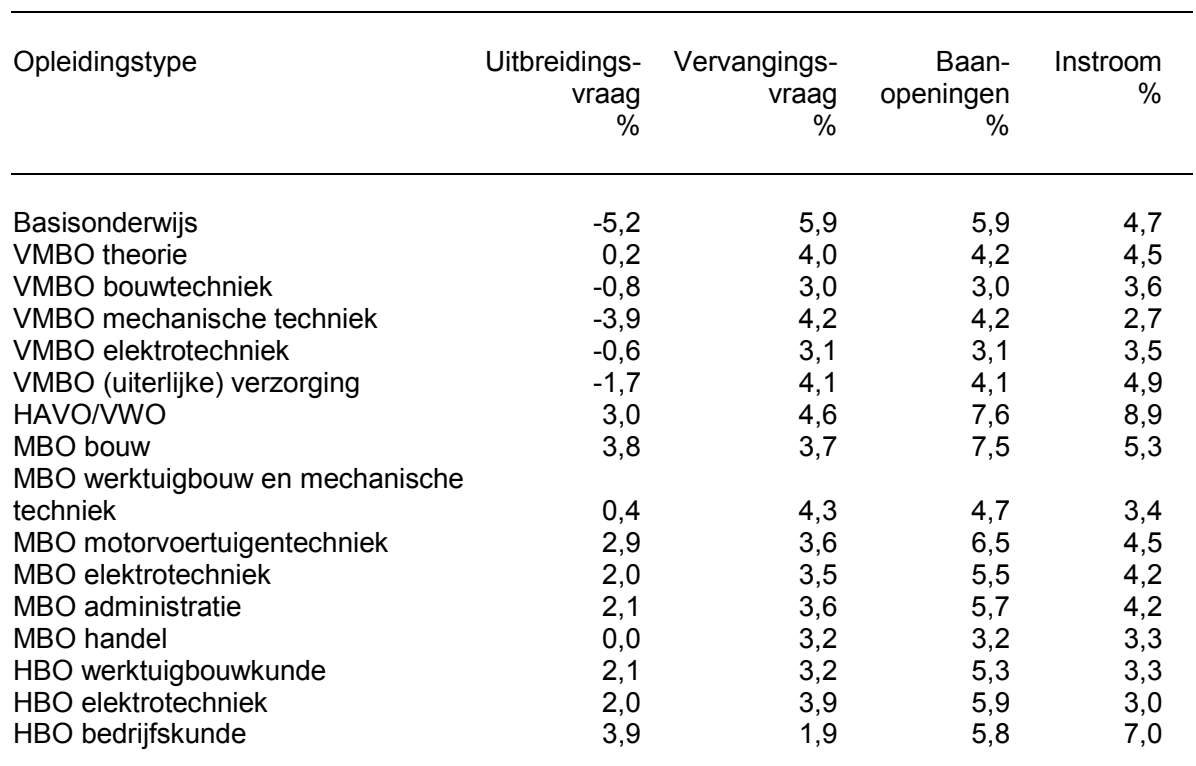

Bron: CBS/CPB/ROA

De vervangingsvraag naar opleidingstype concentreert zicht echter vooral in de lagere opleidingsniveaus, wat verklaard kan worden door het hoge percentage oudere werknemers met lagere opleidingen. De vervangingsvraag is het hoogst voor werknemers met alleen basisonderwijs. Voor de sterk in omvang toenemende groep werkenden met een opleiding $H B O$ bedrijfskunde is de vervangingsvraag het laagst.

In de laatste kolom van tabel 4.4 wordt een overzicht gegeven van de verwachte instroom van schoolverlaters. De hoogste instroom wordt verwacht voor schoolverlaters met $H A V O / V W O$ en $H B O$ bedrijfskunde. De instroom van schoolverlaters is naar verwachting het laagst voor VMBO mechanische techniek, MBO handel en HBO werktuigbouwkunde.

Wanneer de vraag- en aanbodverwachtingen met elkaar geconfronteerd worden krijgen we een indicatie van de verwachte toekomstige knelpunten in de personeelsvoorziening (ITKP).

Uit tabel 4.5 blijkt duidelijk dat de verwachte knelpunten in de personeelsvoorziening met name te verwachten zijn op het MBO-niveau en hoger. Daarentegen zal de vraag naar mensen zonder een zogenaamde 'startkwalificatie' op de arbeidsmarkt achter blijven bij het aanbod. 
Tabel 4.5

Indicator Toekomstige Knelpunten in de Personeelsvoorziening (ITKP) voor de belangrijkste opleidingstypen binnen de Metalektro, 2001-2006

\begin{tabular}{lll}
\hline Opleidingstype & ITKP & Typering \\
& & \\
\hline & & \\
Basisonderwijs & 1,21 & geen \\
VMBO theorie & 1,07 & vrijwel geen \\
VMBO bouwtechniek & 1,21 geen \\
VMBO mechanische techniek & 1,20 geen \\
VMBO elektrotechniek & 1,12 vrijwel geen \\
VMBO (uiterlijke) verzorging & 1,20 geen \\
HAVO/WWO & 1,11 vrijwel geen \\
MBO bouw & 1,00 groot \\
MBO werktuigbouw en mechanische techniek & 1,00 groot \\
MBO motorvoertuigentechniek & 0,98 groot \\
MBO elektrotechniek & 0,99 groot \\
MBO administratie & 0,95 groot \\
MBO handel & 1,03 enige \\
HBO werktuigbouwkunde & 0,89 groot \\
HBO elektrotechniek & 0,87 groot \\
HBO bedrijfskunde & 1,02 enige \\
\end{tabular}

Bron: ROA

\subsection{De mening van bedrijven over de prognoses}

In de managementmeting van het werkgeverspanel Metalektro is onderzocht in hoeverre de prognoses herkend en gedragen worden door de bedrijven in de sector.

Prognose van de werkgelegenheidsontwikkeling in de Metalektro als geheel

In tabel 4.6 wordt de mening van de bedrijven over de verwachte werkgelegenheidskrimp van $4 \%$ in de Metalektro als geheel weergegeven. Het blijkt dat ongeveer eenderde van de bedrijven zich kan vinden in de verwachte werkgelegenheidskrimp in de Metalektro. Per saldo zijn de verwachte werkgelegenheidsontwikkelingen wat positiever dan de ROA prognoses.

Eén op vijf bedrijven geeft aan dat ze geen krimp maar juist groei verwachten. Daarnaast verwacht bijna $20 \%$ van de bedrijven dat de werkgelegenheid stabiel zal blijven. Echter, een vrijwel even grote groep bedrijven verwacht dat de werkgelegenheidskrimp groter zal zijn dan het ROA voorspelt. In de machine-industrie verwacht bijna de helft van de bedrijven een gelijkblijvende of een groeiende werkgelegenheid.

Uit de cijfers blijkt verder dat de grote bedrijven het vaker eens zijn met de negatieve groeivoorspelling dan de kleine en middelgrote bedrijven. Dit zou er op kunnen duiden dat de verwachte werkgelegenheidskrimp zich voor een deel zal concentreren bij de grotere bedrijven. 
Tabel 4.6

Mening van bedrijven over ROA-prognose 'werkgelegenheidsontwikkeling Metalektro-sector = $4 \%$ '

\begin{tabular}{|c|c|c|c|c|c|}
\hline & $\begin{array}{c}\text { Prognose } \\
\text { is juist } \\
\%\end{array}$ & $\begin{array}{l}\text { Krimp is } \\
\text { groter } \\
\%\end{array}$ & $\begin{array}{l}\text { Krimp is } \\
\text { kleiner } \\
\%\end{array}$ & $\begin{array}{c}\text { Werkgelegen- } \\
\text { heid zal } \\
\text { gelijkblijven } \\
\%\end{array}$ & $\begin{array}{c}\text { Werkge- } \\
\text { legenheid } \\
\text { neemt toe } \\
\%\end{array}$ \\
\hline $\begin{array}{l}\text { Metaalproducten } \\
\text { Machine-industrie } \\
\text { Overig }\end{array}$ & $\begin{array}{l}31 \\
32 \\
41\end{array}$ & $\begin{array}{l}22 \\
14 \\
27\end{array}$ & $\begin{array}{r}8 \\
9 \\
12\end{array}$ & $\begin{array}{r}22 \\
25 \\
9\end{array}$ & $\begin{array}{l}17 \\
21 \\
12\end{array}$ \\
\hline $\begin{array}{l}0-100 \text { werknemers } \\
101-250 \text { werknemers } \\
251 \text { of meer werknemers }\end{array}$ & $\begin{array}{l}34 \\
33 \\
43\end{array}$ & $\begin{array}{l}21 \\
17 \\
14\end{array}$ & $\begin{array}{r}9 \\
13 \\
7\end{array}$ & $\begin{array}{l}19 \\
23 \\
14\end{array}$ & $\begin{array}{l}17 \\
13 \\
21\end{array}$ \\
\hline Totaal & 34 & 20 & 10 & 19 & 17 \\
\hline
\end{tabular}

Bron: ROA/Werkgeverspanel Metalektro 2002

\section{Knelpuntberoepen}

Aan de bedrijven is ook gevraagd in hoeverre ze zich kunnen vinden in de prognoses die het ROA opstelt naar de verwachte knelpunten in de verschillende beroepsgroepen. Tabel 4.7 gaat in op de door het ROA verwachte grote knelpunten voor bankwerkers en lassers in 2006.

Tabel 4.7

Mening van bedrijven over ROA-prognose 'grote knelpunten bankwerkers en lassers in 2006'

\begin{tabular}{lcccc}
\hline & $\begin{array}{c}\text { Prognose is } \\
\text { juist } \\
\%\end{array}$ & $\begin{array}{c}\text { Grotere } \\
\text { knelpunten } \\
\%\end{array}$ & $\begin{array}{c}\text { Geringere } \\
\text { knelpunten } \\
\%\end{array}$ & $\begin{array}{c}\text { Niet van } \\
\text { toepassing } \\
\%\end{array}$ \\
\hline Metaalproducten & 50 & 0 & 33 & 17 \\
Machine-industrie & 55 & 2 & 24 & 19 \\
Overig & 40 & 0 & 11 & 49 \\
$0-100$ werknemers & 51 & 0 & 23 & 26 \\
$101-250$ werknemers & 48 & 3 & 17 & 27 \\
251 of meer werknemers & 40 & 0 & 33 & 27 \\
Totaal & 49 & 1 & 23 & 27
\end{tabular}

Bron: ROA/Werkgeverspanel Metalektro 2002

De helft van de bedrijven kan zich in de prognose vinden. Van de bedrijven waarbij dat niet het geval is verwacht het merendeel geen knelpunten of is de vraag in verband met de afwezigheid van bankwerkers en lassers in het bedrijf niet relevant. Slechts een zeer kleine minderheid verwacht dat de knelpunten in hun bedrijf groter zijn dan het ROA voorspelt.

Tabel 4.8 laat zien dat ruim $40 \%$ van de bedrijven zich kan vinden in de prognose van het ROA dat er in 2006 sprake zal zijn van grote knelpunten in de personeelsvoorziening voor monteurs. Het valt op dat de bedrijven in de machine-industrie zich het beste kunnen vinden in de voorspelling. Een beperkt aantal bedrijven verwacht 
nog grotere knelpunten. Daarentegen verwacht bijna 30\% van de bedrijven dat de knelpunten op de arbeidsmarkt voor monteurs geringer zullen zijn. Vooral bedrijven in de metaalproductensector verwachten relatief vaak kleinere knelpunten voor monteurs.

Tabel 4.8

Mening van bedrijven over ROA-prognose 'grote knelpunten monteurs in 2006'

\begin{tabular}{lcccc}
\hline & $\begin{array}{c}\text { Prognose is } \\
\text { juist } \\
\%\end{array}$ & $\begin{array}{c}\text { Grotere knel- } \\
\text { punten } \\
\%\end{array}$ & $\begin{array}{c}\text { Geringere } \\
\text { knelpunten } \\
\%\end{array}$ & $\begin{array}{c}\text { Niet van } \\
\text { toepassing } \\
\%\end{array}$ \\
\hline $\begin{array}{l}\text { Metaalproducten } \\
\text { Machine-industrie }\end{array}$ & 34 & 0 & 37 & 29 \\
Overig & 62 & 5 & 17 & 17 \\
0 - 100 werknemers & 26 & 9 & 34 & 31 \\
101-250 werknemers & 36 & 6 & 30 & 28 \\
251 of meer werknemers & 59 & 3 & 31 & 31 \\
Totaal & 39 & 0 & 29 & 25 \\
\hline Bron: ROAWherkgeverspanel & 42 & 5 & & 21 \\
\hline
\end{tabular}

Bron: ROA/Werkgeverspanel Metalektro 2002

In tabel 4.9 wordt er gekeken naar de prognose voor metaalarbeiders. Ongeveer vier op de tien bedrijven herkent zich in de ROA prognose dat er in 2006 vrijwel geen knelpunten voor metaalarbeiders zullen zijn. In de metaalproductensector en bij de kleinere bedrijven ligt dit cijfer wat lager. Een beperkt aantal bedrijven verwacht helemaal geen knelpunten. Een aanzienlijk deel van de bedrijven verwacht daarentegen voor 2006 wel degelijk knelpunten bij het werven van metaalarbeiders. Vooral bedrijven in de metaalproductenindustie en de kleinere bedrijven geven relatief vaak aan dat ze grotere knelpunten verwachten dan het ROA voorspelt.

Tabel 4.9

Mening van bedrijven over ROA-prognose 'vrijwel geen knelpunten metaalarbeiders in 2006'

\begin{tabular}{|c|c|c|c|c|}
\hline & $\begin{array}{c}\mathrm{Ja}, \\
\text { herkenbaar } \\
\%\end{array}$ & $\begin{array}{c}\text { Nee, hele- } \\
\text { maal geen } \\
\text { knelpunten } \\
\%\end{array}$ & $\begin{array}{c}\text { Nee, grotere } \\
\text { knelpunten } \\
\%\end{array}$ & $\begin{array}{c}\text { Niet van } \\
\text { toepassing } \\
\%\end{array}$ \\
\hline $\begin{array}{l}\text { Metaalproducten } \\
\text { Machine-industrie } \\
\text { Overig }\end{array}$ & $\begin{array}{l}29 \\
41 \\
44\end{array}$ & $\begin{array}{l}6 \\
0 \\
8\end{array}$ & $\begin{array}{l}49 \\
38 \\
19\end{array}$ & $\begin{array}{l}17 \\
21 \\
28\end{array}$ \\
\hline $\begin{array}{l}0-100 \text { werknemers } \\
101-250 \text { werknemers } \\
251 \text { of meer werknemers }\end{array}$ & $\begin{array}{l}28 \\
52 \\
53\end{array}$ & $\begin{array}{l}6 \\
3 \\
0\end{array}$ & $\begin{array}{l}41 \\
28 \\
27\end{array}$ & $\begin{array}{l}26 \\
17 \\
20\end{array}$ \\
\hline Totaal & 38 & 4 & 35 & 22 \\
\hline
\end{tabular}

Bron: ROA/Werkgeverspanel Metalektro 2002 


\section{$5 \quad$ Omgaan met tekorten aan technisch personeel}

\section{$5.1 \quad$ Inleiding}

Hoewel de tekorten aan technisch personeel door de stagnerende economische groei wat minder groot zijn dan het nabije verleden, kampen de bedrijven in de Metalektro zoals in hoofdstuk 3 bleek, nog steeds met moeilijk vervulbare vacatures. Bedrijven kunnen op verschillende manieren op die problemen inspelen. Zo kunnen bedrijven ervoor te zorgen een aantrekkelijke werkgever te worden voor technisch geschoolde mensen. Een andere manier om met tekorten om te gaan richt zich op het personeel dat men in dienst heeft. Door het personeel bijvoorbeeld te laten overwerken kan geprobeerd worden tijdelijke tekorten aan technisch personeel op te vangen. Ook kan geprobeerd worden in moeilijk vervulbare vacatures te voorzien door mensen die men reeds in dienst heeft bij- of om te scholen.

In dit hoofdstuk staat de vraag centraal hoe bedrijven in de Metalektro omgaan met de tekorten aan technisch personeel. In paragraaf 5.2 wordt ingegaan op de aanpassingen die bedrijven in hun werving en selectie treffen om de tekorten te verminderen. Daarbij zal er ook aandacht besteed worden aan de effectiviteit van de verschillende wervingskanalen en de concurrentie die Metalektrobedrijven ondervinden van bedrijven uit de eigen sector en bedrijven uit andere bedrijfssectoren. In paragraaf 5.3 wordt aandacht besteed aan de interne aanpassingen die bedrijven kunnen treffen om personeelstekorten te verminderen. Hierbij zullen instrumenten als overwerk, het 'inlenen' van werknemers en het functioneel flexibel inzetten van het personeel aan de orde komen.

\subsection{Werving en selectie}

Het aanpassen van het wervings- en selectiebeleid als reactie op personeelstekorten komt in de Metalektrosector veelvuldig voor: niet één van de in het werkgeverspanel Metalektro ondervraagde bedrijven geeft aan dat ze geen enkele maatregel treffen op het gebied van werving en selectie om moeilijk vervulbare vacatures in te vullen. In tabel 5.1 wordt een overzicht gegeven van de activiteiten die bedrijven op het vlak van hun werving en selectie ondernemen om moeilijk vervulbare vacatures ingevuld te krijgen.

Het inschakelen van uitzendbureaus of andere commerciële werving- en selectiebureaus is met $80 \%$ veruit de meest populaire maatregel die bedrijven in de Metalektro in hun werving en selectiebeleid toepassen om moeilijk vervulbare vacatures voor technisch personeel op te vullen. De sector maakt, in vergelijking met andere bedrijfssectoren relatief vaak gebruik van dit instrument. Uit ander onderzoek komt namelijk naar voren dat het percentage bedrijven dat bij wervingsproblemen 
een uitzend- of werving- en selectiebureau inschakelt $60 \%$ bedraagt. $^{8}$ Daarnaast geeft ruim de helft van de bedrijven aan wel eens mensen met minder ervaring dan men zou willen aan te trekken om de moeilijk vervulbare vacatures op te vullen. De overige aanpassingen komen slechts in een beperkt deel van de bedrijven voor. Ongeveer een kwart van de bedrijven geeft aan wel eens lager opgeleiden of anders opgeleiden aan te trekken om moeilijk vervulbare vacatures op te vullen. Het arbeidsbureau (CWI) wordt slechts door één op de vijf bedrijven ingeschakeld als reactie op moeilijk vervulbare vacatures. Ook blijkt het slechts in beperkte mate voor te komen dat bedrijven door het bieden van betere arbeidsvoorwaarden of een hoger salaris in hun moeilijk vervulbare vacatures proberen te voorzien. In andere bedrijfssectoren wordt dit instrument vaker gebruikt. Uit het eerder aangehaalde OSA onderzoek blijkt $30 \%$ van de Nederlandse bedrijven een hoger loon te bieden bij wervingsproblemen.

Tabel 5.1

Aanpassingen in werving en selectie van bedrijven met moeilijk vervulbare vacatures voor technisch personeel*

Inschakelen uitzendbureaus of andere commerciële werving- en selectiebureaus

Aantrekken van mensen met minder ervaring

Actiever benaderen van scholieren

Aantrekken van lager opgeleiden

Aantrekken van anders opgeleiden

Inschakelen arbeidsbureau (CWI)

Bieden van een hoger salaris

Bieden van betere, CAO overstijgende arbeidsvoorwaarden

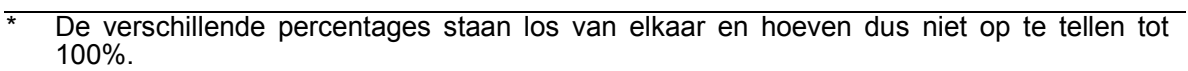

Bron: ROA/ Werkgeverspanel Metalektro 2002

Er zijn overigens wel enkele verschillen tussen de sectoren binnen de Metalektro. Zo trekken de bedrijven in de metaalproductenindustrie vaker lager en anders opgeleiden dan gewenst aan dan de bedrijven in de andere sectoren van de Metalektro. In de machine-industrie worden daarentegen relatief vaak mensen met minder ervaring aangetrokken om in moeilijk vervulbare vacatures te voorzien. Een hoger salaris bieden komt in de metaalproductensector niet voor, terwijl in deze sector het bieden van betere secundaire arbeidsvoorwaarden juist wel relatief vaak plaats vindt. Ten slotte blijkt dat het actiever benaderen van scholieren in zowel de metaalproducten- als de machine-industrie relatief weinig voorkomt in vergelijking met de andere sectoren.

De middelgrote bedrijven trekken het vaakst lager opgeleiden aan om vacatures te vervullen. Werknemers met minder ervaring aantrekken gebeurt relatief vaak in de kleine bedrijven. Ook het bieden van een hoger salaris of betere arbeidsvoorwaarden

8. P. Visser, C. Remery, K. Henkens, en J. Schippers (2003). Hoe werven werkgevers: structerele aanpak personeelsvoorziening in Nederland (OSA-Publicatie A193). Tilburg: Organisatie voor Strategisch Arbeidsmarktonderzoek. 
is vooral een maatregel die kleine bedrijven toepassen. Het inschakelen van het arbeidsbureau om in moeilijk vervulbare vacatures te voorzien is daarentegen vooral populair bij de grote bedrijven.

\section{Wervingskanalen}

In tabel 5.2 wordt een overzicht gegeven van de effectiviteit van de wervingskanalen volgens de bedrijven in de Metalektro. De meeste bedrijven (ruim 40\%) geven aan dat ze werven via een uitzendbureau het meest effectief vinden. Het is opmerkelijk dat het werven via het arbeidsbureau (CWI) op dit punt geen reëel alternatief is. Eén op vijf bedrijven vindt dat adverteren in een regionaal dagblad het beste werkt om personeel aan te werven. $7 \%$ vindt dat het werven via een commercieel wervingsbureau het beste werkt terwijl een zelfde deel van de bedrijven vindt dat werven via scholen/opleidingen het meest effectief is. $6 \%$ van de bedrijven werft onder het eigen personeel. Eén op twintig bedrijven gebruikt externe relaties bij het werven. De overige kanalen worden door een gering aantal van de bedrijven aangemerkt als meest effectief.

Tabel 5.2

Effectiviteit van wervingskanalen voor bedrijven in de Metalektro

Via uitzendbureau werven

Via advertentie in regionaal dagblad werven

Via commercieel wervingsbureau werven

Via school/opleiding werven

Via eigen personeel in bedrijfsvestiging werven

Via externe relaties werven

Via advertentie in vakblad werven

Via open sollicitaties werven

Via personeel van de andere vestiging(en) werven

Via advertentie in landelijk dagblad werven

Via arbeidsbureau (CWI) werven

Bron: ROA/ Werkgeverspanel Metalektro 2002

Tussen verschillende sectoren in de Metalektro is er slechts een beperkt aantal verschillen in de effectiviteit van de wervingskanalen. Wat wel opvalt is dat adverteren in een regionaal dagblad door de bedrijven in de machine-industrie minder vaak als meest effectief gezien wordt. De metaalproductenbedrijven vinden het uitzendbureau relatief vaak het meest effectieve wervingskanaal. Daarnaast blijkt dat met name de middelgrote bedrijven het werven via het eigen personeel in de eigen vestiging het meest effectief vinden om in hun vacatures te voorzien.

\section{Concurrentie bij de werving van technisch personeel}

In tabel 5.3 wordt een overzicht gegeven van de mate waarin bedrijven aangeven concurrentie te ondervinden bij de werving van technisch personeel vanuit verschillende hoeken. Ongeveer eenderde van de bedrijven ondervindt (zeer) veel concurrentie door bedrijven in de regio. Bedrijven buiten de regio leveren weinig concurrentie wanneer het gaat om het aantrekken van personeel. Ook de concurrentie met 
bedrijven uit andere sectoren in de regio is beperkt. Slechts $15 \%$ van de bedrijven geeft aan veel of zeer veel concurrentie te ervaren van deze bedrijven.

Tabel 5.3

Concurrentie bij de werving van technisch personeel in de Metalektrosector, naar soort bedrijf

\begin{tabular}{lcrcrc}
\hline Concurrentie & $\begin{array}{c}\text { Zeer } \\
\text { veel } \\
\%\end{array}$ & $\begin{array}{c}\text { Veel } \\
\%\end{array}$ & $\begin{array}{c}\text { Niet veel, } \\
\text { niet weinig } \\
\%\end{array}$ & $\begin{array}{c}\text { Weinig } \\
\%\end{array}$ & $\begin{array}{c}\text { Zeer } \\
\text { weinig } \\
\%\end{array}$ \\
\hline $\begin{array}{l}\text { Bedrijven in de regio } \\
\text { Bedrijven buiten de regio }\end{array}$ & 5 & 26 & 43 & 13 & 14 \\
$\begin{array}{l}\text { Niet-Metalektro bedrijven in de regio } \\
\text { Niet-Metalektro bedrijven buiten de regio }\end{array}$ & 1 & 9 & 21 & 34 & 35 \\
& 1 & 12 & 30 & 31 & 25 \\
& & 3 & 18 & 26 & 52 \\
\hline
\end{tabular}

Bron: ROA/Werkgeverspanel Metalektro 2002

In tabel 5.4 wordt aangegeven van welke bedrijfssectoren de bedrijven uit de Metalektro concurrentie ondervinden bij het werven van personeel. De Metalektro ondervindt, zoals ook verwacht zou mogen worden, bij de werving van personeel de meeste concurrentie van de sector kleinmetaal. Meer dan $80 \%$ van de bedrijven geeft dit aan. De sector chemie en de transport en communicatiesector volgen op ruime afstand. Slechts ongeveer één op vijf bedrijven uit de Metalektro geeft aan op de arbeidsmarkt voor technisch personeel concurrentie van deze sectoren te ondervinden, terwijl circa één op tien bedrijven concurrentie ondervindt van de zakelijke dienstverlening/ICT en de energiesector. De overige sectoren spelen slechts een marginale rol bij de concurrentie bij de werving van technisch personeel.

Tabel 5.4

Concurrentie van niet-Metalektrobedrijven bij de werving van technisch personeel in de Metalektrosector, naar sector*

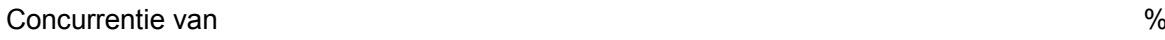

Kleinmetaal $\quad 82$

Chemie

$\begin{array}{ll}\text { Transport en communicatie } & 19\end{array}$

Zakelijke dienstverlening/ICT

(20

$\begin{array}{ll}\text { Hout- en bouwmaterialen industrie } & 7 \\ \text { Handel } & 6\end{array}$

Bouw en onroerend goed 5

Overheid en onderwijs 2

Textiel-industrie

Papierindustrie

Grafische industrie

* De verschillende percentages staan los van elkaar en hoeven dus niet op te tellen tot $100 \%$.

Bron: ROA/ Werkgeverspanel Metalektro 2002

Uit achterliggende cijfers blijkt dat de machine-industrie bij het werven van technisch personeel relatief weinig concurrentie ondervindt van de chemie terwijl de concurrentie bij de werving vanuit de sector hout- en bouwmaterialen juist veel hoger is dan het gemiddelde. Ook is er bij kleine bedrijven minder concurrentie van de 
chemiesector dan bij middelgrote of grote bedrijven. De middelgrote bedrijven ondervinden daarentegen weer minder concurrentie op de arbeidsmarkt van de sector transport en communicatie dan de kleine en de grote bedrijven. Grote Metalektrobedrijven geven relatief vaak aan dat ze bij het werven van personeel concurrentie ondervinden van de zakelijke dienstverlening/ICT.

\section{Wervingsvoorkeuren}

De keuze tussen schoolverlaters met een relevant vakdiploma en werkenden met relevante werkervaring bij het invullen van vacatures kwam al eerder aan de orde in hoofdstuk 2. In tabel 5.5 wordt de keuze tussen schoolverlaters en werkenden met relevante ervaring gerelateerd aan het aantal vacatures dat een bedrijf heeft openstaan.

Wanneer er sprake is van weinig of geen vacatures geeft $72 \%$ van de bedrijven de voorkeur aan werkenden met relevante werkervaring terwijl $28 \%$ schoolverlaters prefereert. Bij een iets groter aantal vacatures heeft $86 \%$ procent een voorkeur voor werkenden met relevante ervaring. Wanneer er sprake is van veel vacatures is het percentage bedrijven dat de voorkeur geeft aan schoolverlaters met $30 \%$ het hoogst. Tabel 5.5 laat daarmee duidelijk zien dat er een verband is tussen het aantal vacatures en de wervingsvoorkeuren van bedrijven in de Metalektro.

Tabel 5.5

Voorkeur bij opvullen van vacatures

\begin{tabular}{lcc}
\hline & $\begin{array}{c}\text { Schoolverlater met } \\
\text { relevant vakdiploma } \\
\%\end{array}$ & $\begin{array}{c}\text { Werkende met } \\
\text { relevante } \\
\text { werkervaring } \\
\%\end{array}$ \\
\hline Bedrijven met weinig of geen vacatures $(0-1 \%)$ & 28 & 72 \\
Bedrijven met enige vacatures (1-6\%) & 14 & 86 \\
Bedrijven met veel vacatures $(6 \%$ of meer) & 30 & 70 \\
Totaal & 23 & 77 \\
\hline
\end{tabular}

Bron: ROA/Werkgeverspanel Metalektro 2002

\subsection{Interne aanpassingen}

Ruim $70 \%$ van de bedrijven in de Metalektro geeft aan dat ze interne maatregelen treffen om de problemen als gevolg van moeilijk vervulbare vacatures te beperken. Het blijkt dat dit met name het geval is bij de middelgrote en grote bedrijven, maar ook bij de kleinere bedrijven geeft nog ruim de helft aan dat ze interne maatregelen treffen om de problemen in de personeelsvoorziening te lijf te gaan.

Tabel 5.6 geeft een overzicht van de gebruikte instrumenten om moeilijk vervulbare vacatures voor technisch personeel op te vullen. Overwerk en het flexibel inzetten van het huidige personeel komt het vaakst voor: ongeveer $70 \%$ van de bedrijven in de Metalektro geeft aan deze maatregelen toe te passen. Het uitbesteden van werk aan binnenlandse bedrijven en het intern om- of bijscholen van het personeel is ook 
een vaak toegepaste maatregel om de personeelsproblemen te bestrijden. Bijna $60 \%$ van de bedrijven geeft aan deze toe te passen. Het uitbesteden van werk aan buitenlandse bedrijven komt in één op vier Metalektrobedrijven voor. Als deze ontwikkeling structureel van aard is, bestaat het gevaar dat op de lange termijn een deel van de werkgelegenheid in de Metalektro zich permanent naar het buitenland verplaatst. De laatste twee maatregelen die in de tabel genoemd worden, namelijk automatiseren of de productie beperken, speelt slechts in een minderheid van de Metalektrobedrijven een rol. In minder dan één van de vijf bedrijven worden deze interne maatregelen gebruikt om met moeilijk vervulbare vacatures om te gaan.

Tabel 5.6

Interne maatregelen van bedrijven met moeilijk vervulbare vacatures voor technisch personeel*

$\begin{array}{ll}\text { Maatregelen } & \%\end{array}$

Overwerk

Flexibel inzetten van huidige werknemers

Uitbesteden van werk (binnenland)

Intern omscholen of bijscholen van huidige werknemers

Uitbesteden van werk (buitenland)

Automatiseren

Productie beperken

* De verschillende percentages staan los van elkaar en hoeven dus niet op te tellen tot
$100 \%$. Bron: ROA/ Werkgeverspanel Metalektro 2002

Enkele verschillen tussen bedrijfssectoren en bedrijven van verschillende omvang zijn de volgende. Allereerst blijkt dat het om- en bijscholen van het zittende personeel en het automatiseren om met moeilijk vervulbare vacatures om te gaan vooral belangrijk zijn in de sector metaalproducten. Overwerk is daarentegen van groter belang in de machine-industrie. Het uitbesteden van werk aan binnenlandse bedrijven is in zowel de metaalproducten als in de machine-industrie populair, terwijl er in de overige sectoren minder gebruik van gemaakt wordt. Dit geldt ook voor het beperken van de productie.

Daarnaast valt op dat kleine bedrijven minder vaak hun personeel om- of bijscholen als reactie op knelpunten in de personeelsvoorziening dan middelgrote of grote bedrijven. Vermoedelijk heeft dit te maken met het feit dat juist de kleine bedrijven minder opleidingsfaciliteiten ter beschikking hebben dan de grote bedrijven, hetgeen deze maatregel voor hen een relatief dure optie maakt. Het uitbesteden van werk aan binnenlandse bedrijven en het beperken van de productie komt daarentegen vooral voor bij de kleine bedrijven. Wellicht heeft dit te maken met het feit dat andere maatregelen zoals bij- en omscholing minder geschikte opties zijn voor de kleine bedrijven, waardoor ze bij knelpunten min of meer genoodzaakt worden te kiezen voor de wat meer drastische maatregelen als uitbesteding en productiebeperking.

\section{Overwerk}

Overwerk geeft bedrijven de mogelijkheid om met hetzelfde aantal personeelsleden de productie te verhogen en kan daarom gezien worden als een alternatief voor het 
aannemen van nieuw personeel dat in ieder geval op de korte termijn enig soelaas voor de werkgevers biedt. Tabel 5.7 geeft een overzicht van de mate waarin er binnen de bedrijven in de Metalektro overgewerkt wordt.

Bijna acht op tien bedrijven geeft aan dat de belangrijkste reden van het inzetten van overwerk het opvangen van tijdelijke schommelingen in de bedrijfsdrukte is. In bijna $10 \%$ van de bedrijven is er daarentegen sprake van structureel overwerk. Overwerk komt het meeste voor in de machine-industrie. Daarnaast blijkt structureel overwerk vooral voor te komen bij de grote bedrijven.

Tabel 5.7

Frequentie van overwerk

\begin{tabular}{lcccc}
\hline & $\begin{array}{c}\text { Structureel } \\
\%\end{array}$ & $\begin{array}{c}\text { Soms } \\
\%\end{array}$ & $\begin{array}{c}\text { Zeer zelden } \\
\%\end{array}$ & $\begin{array}{c}\text { Nooit } \\
\%\end{array}$ \\
\hline Metaalproducten & 5 & 88 & 7 & 0 \\
Machine-industrie & 12 & 80 & 8 & 0 \\
Overig & 11 & 71 & 15 & 3 \\
0 - 100 werknemers & 10 & 81 & 7 & 2 \\
101-250 werknemers & 8 & 79 & 13 & 0 \\
251 of meer werknemers & 18 & 79 & 4 & 0 \\
Totaal & 9 & 80 & 10 & 1 \\
\hline
\end{tabular}

Bron: ROA/Werkgeverspanel Metalektro 2002

Inleen

Ook het inlenen van technisch personeel kan een tijdelijke oplossing zijn voor een tekort aan technici. Tabel 5.8 laat zien dat $65 \%$ van de bedrijven in de Metalektro minder dan $5 \%$ van het technisch personeel inleent. $35 \%$ heeft echter een personeelsbestand dat voor meer dan vijf procent uit ingeleende arbeidskrachten bestaat.

Tabel 5.8

Inleen van technisch personeel

\begin{tabular}{lcc}
\hline & $\begin{array}{c}\text { Weinig inleen } \\
(<5 \%) \\
\%\end{array}$ & $\begin{array}{c}\text { Veel inleen } \\
(>5 \%) \\
\%\end{array}$ \\
\hline Metaalproducten & 69 & 31 \\
Machine-industrie & 73 & 27 \\
Overig & 52 & 48 \\
$0-100$ werknemers & 69 & 31 \\
$101-250$ werknemers & 56 & 44 \\
251 of meer werknemers & 46 & 54 \\
Totaal & 65 & 35 \\
\hline
\end{tabular}


De belangrijkste reden voor het inzetten van ingeleend personeel is echter niet het tekort aan personeel. De meeste bedrijven geven namelijk aan dat ze personeel inlenen om schommelingen in de bedrijfsdrukte op te vangen. Sommige bedrijven geven daarnaast aan dat het inlenen van personeel goedkoper is dan het aanstellen van vaste werknemers. Ook het hebben van tijdelijke werkzaamheden wordt genoemd als reden voor het inlenen van personeel.

\section{Contractvorm}

Ook het aanstellen van werknemers met een tijdelijk dienstverband kan problemen bij het aantrekken van personeel verzachten. Tabel 5.9 biedt inzicht in de mate waarin bedrijven gebruik maken van personeel met een tijdelijk dienstverband. Uit de tabel blijkt dat bij bijna $30 \%$ van de bedrijven meer dan $5 \%$ van het technisch personeel een tijdelijk dienstverband heeft. De bedrijven in de machine-industrie hebben minder vaak veel werknemers met een tijdelijk dienstverband in dienst dan de bedrijven in de andere sectoren binnen de Metalektro. Het aandeel van tijdelijk aangestelde werknemers is het hoogst in de grote bedrijven.

Tabel 5.9

Het aanstellen van werknemers met een tijdelijk dienstverband

\begin{tabular}{lcc}
\hline & $\begin{array}{c}\text { Weinig } \\
\%\end{array}$ & $\begin{array}{c}\text { Veel }(<5 \%) \\
\%\end{array}$ \\
\hline Metaalproducten & 71 & 29 \\
Machine-industrie & 77 & 23 \\
Overig & 67 & 33 \\
$0-100$ werknemers & 73 & 27 \\
$101-250$ werknemers & 64 & 36 \\
251 of meer werknemers & 79 & 21 \\
Totaal & 72 & 28 \\
\hline Bron: ROAMerkgeverspanel & &
\end{tabular}

Bron: ROA/Werkgeverspanel Metalektro 2002

De belangrijkste reden voor het gebruik maken van tijdelijke contracten is dat het een tijdelijk contract een langere proeftijd voor nieuw personeel mogelijk maakt. Bijna $60 \%$ van de bedrijven uit de Metalektro geeft dit aan. Dit wijst erop dat het aanstellen van technisch personeel op basis van een tijdelijk contract bij de meeste bedrijven niet primair een middel is om de personeelsproblematiek te verlichten. Minder dan $30 \%$ van de bedrijven in de Metalektro werkt met tijdelijke contracten om de schommelingen in de bedrijfsdrukte op te vangen.

\section{Functionele inzetbaarheid}

De mate waarin het technisch personeel van een bedrijf functioneel flexibel ingezet kan worden kan ook bijdragen aan het oplossen van knelpunten in de personeelsvoorziening. Het biedt de mogelijkheid om met het zittende personeel meer en/of taken uit te voeren. Tabel 5.10 geeft een overzicht van de mate waarin bedrijven 
aangeven dat ze hun personeel taken laten uitvoeren die niet tot de eigen functie behoren.

Bij de meeste bedrijven (ruim 70\%) verricht het personeel geen taken die niet tot de eigen functie behoren. Wanneer het personeel wel andere taken uitvoert dan gaat het meestal om taken uit functies van een gelijk niveau. De sector metaalproducten valt op doordat hier het aantal bedrijven dat aangeeft dat het personeel geen andere taken uitvoert, het hoogst is. Daarnaast blijkt dat vooral de grote bedrijven het personeel andere taken laten uitvoeren. De belangrijkste reden voor de bedrijven om hun personeel andere taken te laten uitvoeren is het schommelen van de bedrijfsdrukte. Ook als een bedrijf te maken krijgt met eenmalige of tijdelijke werkzaamheden komt het voor dat medewerkers taken uitvoeren die niet tot hun eigen functie behoren. Slechts een klein gedeelte van de bedrijven (5\%) geeft aan dat ze door het personeel andere taken te laten uitvoeren proberen de inzetbaarheid van de medewerkers te bevorderen.

Tabel 5.10

Mate waarin technisch personeel taken verricht die niet tot de eigen functie behoren

\begin{tabular}{lcccc}
\hline Concurrentie & $\begin{array}{c}\text { Taken uit } \\
\text { hogere functies } \\
\%\end{array}$ & $\begin{array}{c}\text { Taken uit } \\
\text { functies van } \\
\text { gelijk niveau } \\
\%\end{array}$ & $\begin{array}{c}\text { Taken uit lagere } \\
\text { functies } \\
\%\end{array}$ & $\begin{array}{c}\text { Geen } \\
\text { andere } \\
\text { taken } \\
\%\end{array}$ \\
\hline Metaalproducten & 1 & 14 & 1 & 84 \\
Machine-industrie & 3 & 23 & 5 & 69 \\
Overig & 3 & 27 & 8 & 62 \\
$0-100$ werknemers & 2 & 24 & 5 & 70 \\
$101-250$ werknemers & 2 & 21 & 4 & 73 \\
251 of meer werknemers & 3 & 35 & 7 & 55 \\
Totaal & 2 & 21 & 5 & 72 \\
\hline Bron: & & & & \\
\hline
\end{tabular}

Bron: ROA/Werkgeverspanel Metalektro 2002 



\section{Competentieontwikkeling in de Metalektro}

\subsection{Inleiding}

In dit hoofdstuk staat de competentieontwikkeling van het technisch personeel in de Metalektro centraal. Om hun functie goed te kunnen uitoefenen moeten werknemers beschikken over bepaalde competenties, die zowel vakspecifiek als meer algemeen van aard zijn. Deze kennis en vaardigheden kunnen op verschillende manieren aangeleerd worden: in het initiële onderwijs, door te leren op de werkplek en door het volgen van cursussen. Vanzelfsprekend is het voor zowel de werknemers zelf als hun werkgever van belang om de aangeleerde competenties op peil te houden. Door technologische, organisatorische en economische ontwikkelingen verandert regelmatig de aard van het werk en daarmee ook de voor dit werk vereiste kennis en vaardigheden. Naast het leren op de werkplek, is het volgen van aanvullende scholing daarom een onmisbaar instrument om kwalificatieveroudering tegen te gaan.

De competentieontwikkeling van werknemers moet ook niet los gezien worden van hun employability. Employability kan daarbij gezien worden als het in staat zijn en de wens hebben om blijvend aantrekkelijk te zijn voor de arbeidsmarkt door te reageren en te anticiperen op veranderingen in arbeidstaken en werkomgeving. ${ }^{9}$ Door deel te nemen aan opleidingen, trainingen en cursussen kunnen werknemers hun competenties verbeteren, kwalificatieveroudering tegengaan en daarmee hun arbeidsmarktpositie versterken.

In paragraaf 6.2 wordt eerst het competentieniveau van het technisch personeel in de Metalektro in kaart gebracht. Over welke algemene en vakspecifieke kennis en vaardigheden beschikken technische werknemers? En hoe zit het met de competenties van nieuwe werknemers? Paragraaf 6.3 gaat na in hoeverre het belang van bepaalde competenties voor het goed functioneren van technische werknemers het afgelopen jaar veranderd is. Tevens wordt beschreven wat de belangrijkste oorzaken voor deze veranderingen zijn en hoe bedrijven hierop inspelen. Paragraaf 6.4 sluit af met een beschrijving van de participatie van het technisch personeel in de Metalektro in interne en externe cursussen. Er wordt onderzocht welke cursussen het meest gevolgd worden en welke belemmeringen bedrijven ondervinden bij de cursusparticipatie van hun werknemers.

\subsection{Competenties van het technisch personeel}

Uit hoofdstuk 1 bleek dat 63\% van het personeel in de Metalektro beschikt over een startkwalificatie voor de arbeidsmarkt op MBO niveau of hoger. Wel blijft het percentage hoger opgeleiden (dat wil zeggen werknemers met een HBO of universitaire opleiding) met $18 \%$ wat achter bij andere sectoren. Opvallend is dat

9. A. de Grip, J. van Loo en J. Sanders (1999), Employability in bedrijf: naar een Employability Index voor bedrijfssectoren, ROA-R-1998/10, Maastricht. 
grote bedrijven niet significant meer hoger opgeleiden in dienst hebben dan kleine bedrijven.

Tabel 6.1 laat zien dat het over het algemeen goed gesteld is met het competentieniveau van het technisch personeel in de Metalektro. Een ruime meerderheid van de bedrijven geeft aan dat hun technische werknemers over voldoende of goede/uitstekende competenties beschikken. Vooral de vaktechnische vaardigheden springen er in dit opzicht uit. Bijna de helft van de bedrijven vindt dat hun technisch personeel goed of zelfs uitstekend scoort op deze vaardigheden, en nog eens $41 \%$ van de bedrijven vindt het niveau in deze vaardigheden voldoende. Hoewel dit betekent dat $90 \%$ van de bedrijven tevreden is met de vaktechnische competenties van hun technici, betekent het ook dat één op de tien bedrijven aangeeft dat hun technisch personeel bepaalde vaktechnische vaardigheden onvoldoende of matig beheerst. Ook vinden bedrijven dat het 'probleemoplossend vermogen' van hun technisch personeel soms tekort schiet. Maar liefst 37\% van de bedrijven in de Metalektro typeert het probleemoplossend vermogen van hun technische werknemers als onvoldoende of matig. Met de commerciële vaardigheden van het technisch personeel is het nog wat minder rooskleurig gesteld. Maar liefst $46 \%$ van de bedrijven vindt dat hun technisch personeel over onvoldoende of matige commerciële vaardigheden beschikt. Ook het niveau in de meer algemene competenties 'communicatie' (40\%) en 'leidinggeven' (38\%) wordt door veel bedrijven als onvoldoende of matig gezien.

Tabel 6.1

Competentieniveau van technische werknemers volgens bedrijven in de Metalektro

\begin{tabular}{lccc}
\hline Competentie & $\begin{array}{c}\text { Onvoldoende/ } \\
\text { matig } \\
\%\end{array}$ & Voldoende & Goed/uitstekend \\
\hline Vaktechnische vaardigheden & 10 & $\%$ & 49 \\
Werken met computer / IT & 27 & 41 & 20 \\
Probleemoplossend vermogen & 37 & 53 & 20 \\
Werken in teamverband & 20 & 43 & 27 \\
Zelfstandig werken & 20 & 53 & 13 \\
Leidinggeven & 38 & 49 & 8 \\
Communicatie & 40 & 52 & 12 \\
Commerciële vaardigheden & 46 & 41 & \\
\hline
\end{tabular}

Bron: ROA/Werkgeverspanel Metalektro 2002

Het competentieniveau van technici in grote bedrijven wijkt niet significant af van het competentieniveau van het technisch personeel in kleine bedrijven. Wel geven bedrijven met minder dan 100 werknemers veel vaker aan dat hun technische werknemers onvoldoende of matig scoren op de competentie 'zelfstandig werken'. De verschillen tussen bedrijven uit de verschillende sectoren binnen de Metalektro zijn ook niet groot. In het algemeen vinden bedrijven in de machine-industrie wat minder vaak dat hun technisch personeel over onvoldoende of matige competenties beschikken. Zij zijn vooral veel positiever over het probleemoplossend vermogen van hun technische werknemers. Daarnaast blijken bedrijven waar veel hoogopgeleiden 
met een $\mathrm{HBO}$ of universitaire opleiding werken, technici in dienst te hebben die beter scoren op IT vaardigheden.

Hoe zit het met de competenties van de nieuw aangenomen technische werknemers? Figuur 6.1 laat zien dat geen enkel bedrijf in de Metalektro vindt dat de kennis en vaardigheden van nieuw personeel met een afgeronde technische opleiding uitstekend aansluiten op de gevraagde kennis en vaardigheden. Het is overduidelijk dat het erg moeilijk is om technisch personeel te werven dat aan alle competentie-eisen voldoet. Ruim de helft van de bedrijven is echter niet echt ontevreden. $56 \%$ van de bedrijven typeert de aansluiting tussen de gevraagde kennis en vaardigheden en de kennis en vaardigheden van nieuw aangenomen technisch personeel als redelijk goed. Daarentegen sluiten in $38 \%$ van de bedrijven de competenties van het nieuw aangestelde personeel slechts een beetje aan. De hiaten in de kennis en vaardigheden van nieuwkomers zullen hier aangevuld moeten worden door middel van (intrede-) scholing op de werkplek of door werknemers specifieke cursussen te laten volgen. De grootste problemen spelen zich af in de bedrijven waar de kennis en vaardigheden helemaal niet aansluiten (6\%).

Figuur 6.1

Beoordeling van de aansluiting tussen de competenties van nieuwe technische werknemers en de gevraagde competenties

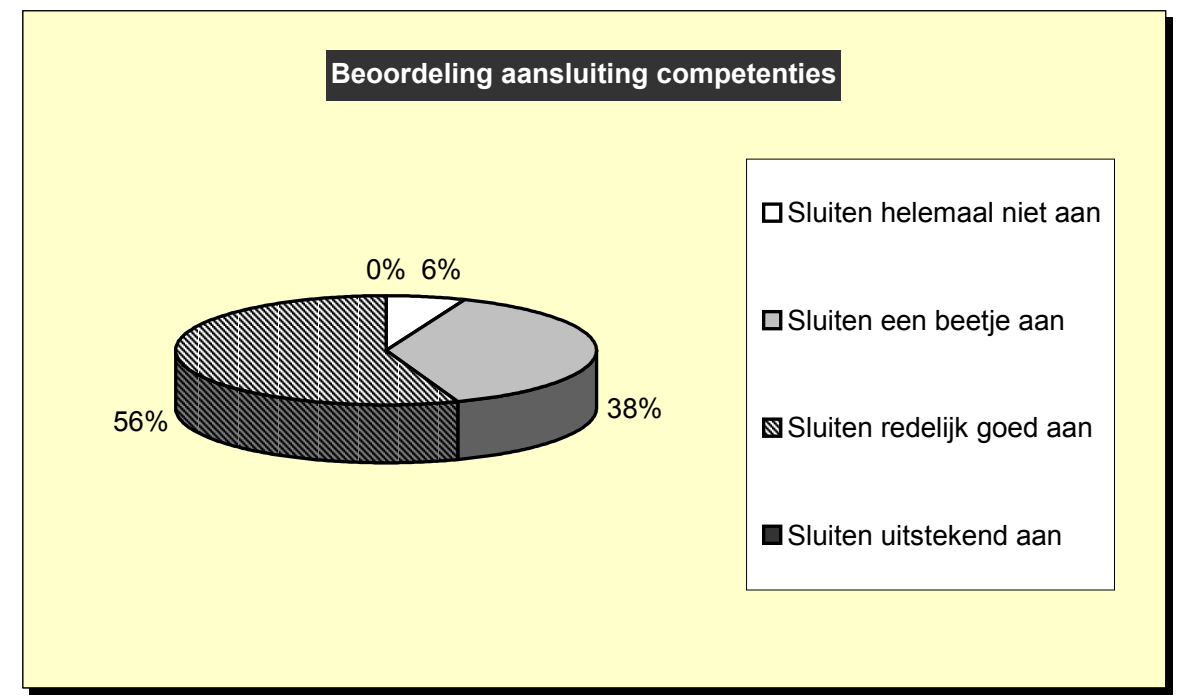

Bron: ROA/Werkgeverspanel Metalektro 2002

Kleine bedrijven melden overigens veel vaker dan grote bedrijven dat de competenties van nieuwe technische werknemers niet aansluiten op de gevraagde competenties. Blijkbaar hebben kleine bedrijven meer moeite met het werven van geschikt technisch personeel dan de grote bedrijven, die kennelijk een grotere wervingskracht hebben (zie ook hoofdstuk 3). Een andere mogelijke verklaring is dat het technisch personeel in kleinere bedrijven wellicht over meer competenties moet beschikken. Bedrijven in de machine-industrie geven vaker aan dat de aansluiting 
tussen de gevraagde en de aanwezige competenties goed is dan bedrijven uit andere sectoren binnen de Metalektro. Ten slotte blijkt dat maar liefst $77 \%$ van de bedrijven in de regio Noord vindt dat de competenties van nieuwe technische werknemers redelijk goed aansluiten bij de door hen gevraagde competenties. Daar staat tegenover dat bedrijven in het Westen van het land veel vaker dan bedrijven in de rest van het land aangeven dat de competenties van het technisch personeel dat ze hebben aangetrokken helemaal niet aansluiten (15\% versus $6 \%$ ).

\subsection{Veranderingen in competenties}

In hoeverre is het competentieniveau van technische werknemers in de Metalektro veranderd? Figuur 6.2 laat zien dat meer dan de helft van de bedrijven vindt dat het niveau van de vaktechnische vaardigheden van hun technisch personeel in 2002 toegenomen is ten opzichte van het niveau in 2001 . Bijna $40 \%$ is van mening dat het niveau van deze vaardigheden gelijk is gebleven, terwijl slecht $7 \%$ van de bedrijven vindt dat het niveau is afgenomen. Deze cijfers illustreren dat er duidelijk sprake is geweest van een upgrading van de vaktechnische competenties van het technisch personeel in de Metalektro. Er zijn op dit punt geen duidelijke verschillen tussen kleine en grote bedrijven, noch tussen bedrijven uit verschillende sectoren. Wel blijken bedrijven in de regio's West en Oost vaker aan te geven dat het niveau van de vaktechnische vaardigheden van hun technisch personeel toegenomen is. Bedrijven in de regio Noord vinden daarentegen vaker dat het niveau van hun technische werknemers gelijk gebleven is.

Figuur 6.2

Veranderingen in het niveau van de vaktechnische vaardigheden van technische werknemers

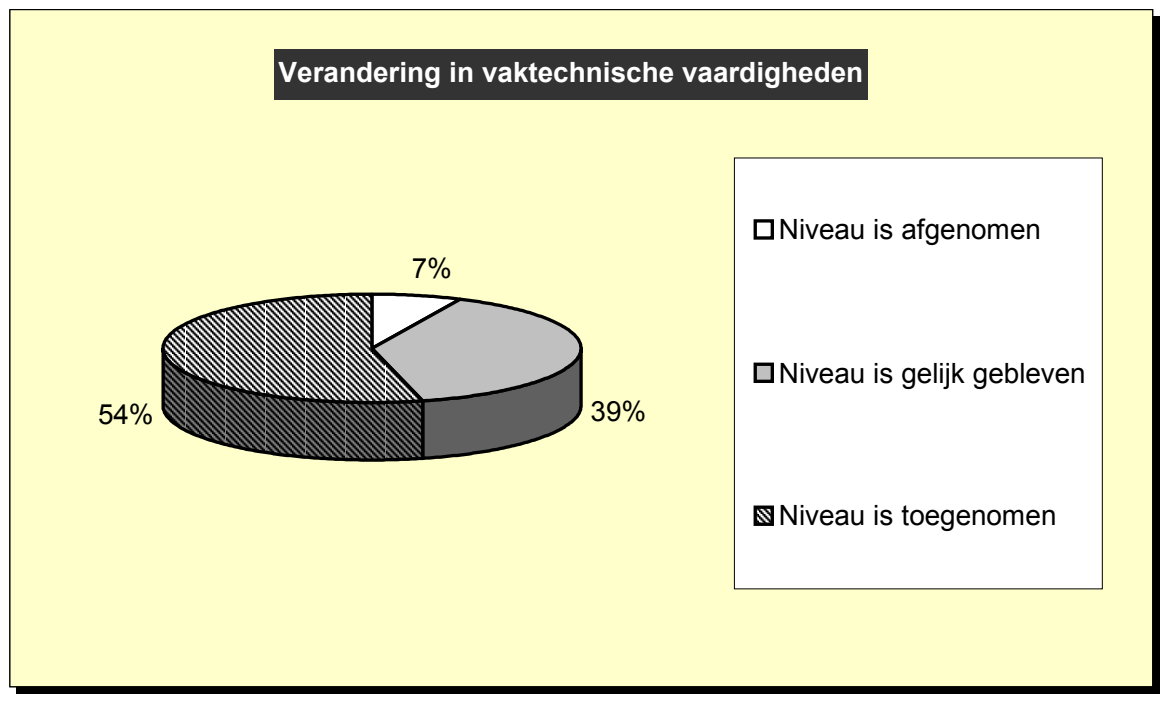

Bron: ROA/Werkgeverspanel Metalektro 2002 


\section{Veranderingen in het belang van competenties}

Naast veranderingen in het competentieniveau van het technisch personeel, kunnen er ook veranderingen zijn opgetreden in het belang van bepaalde competenties voor het adequaat uitoefenen van het werk. Zo wordt er nogal eens aangenomen dat ongeschoolde arbeid steeds meer uit Nederland zal verdwijnen, als gevolg van technologische en organisatorische vernieuwingen en het verplaatsen van ongeschoold werk naar lagelonenlanden.

Om na te gaan in hoeverre dit het geval is in de Metalektro is aan bedrijven de volgende stelling voorgelegd: "Het vereiste niveau van kennis en vaardigheden voor technische functies in mijn bedrijf is de afgelopen jaren steeds hoger geworden". Tabel 6.2 geeft aan dat maar liefst $82 \%$ van de bedrijven het hier (sterk) mee eens is. In deze bedrijven zal het competentieniveau van het technisch personeel ook moeten toenemen, willen zij hun werk adequaat kunnen blijven uitoefenen. Het is dan ook treffend dat in bijna $60 \%$ van deze bedrijven de toenemende competentie-eisen inderdaad gepaard gaan met een stijgend niveau in vaktechnische vaardigheden van technici. De overige $40 \%$ van de bedrijven lijkt echter onvoldoende in te spelen op de upgrading van de kwalificatie-eisen voor hun technisch personeel.

$14 \%$ van de bedrijven in de Metalektro is het overigens oneens met de stelling dat het vereiste niveau van kennis en vaardigheden toegenomen is; $5 \%$ heeft geen mening. Grote en kleine bedrijven denken niet afwijkend van elkaar over de upgrading van kwalificatie-eisen voor hun technisch personeel. Ook zijn er geen duidelijke regionale verschillen of verschillen tussen bedrijven uit verschillende sectoren binnen de Metalektro.

Tabel 6.2

Beoordeling van de stelling "Het vereiste niveau van kennis en vaardigheden voor technische functies in mijn bedrijf is de afgelopen jaren steeds hoger geworden"

\begin{tabular}{lc} 
Beoordeling stelling & $\%$ \\
\hline Sterk mee eens & 7 \\
Mee eens & 75 \\
Mee oneens & 13 \\
Sterk mee oneens & 1 \\
Weet niet / geen mening & 5
\end{tabular}

Bron: ROA/Werkgeverspanel Metalektro 2002

Uit figuur 6.3 blijkt dat het in 2002 met name belangrijker geworden is dat het technisch personeel beschikt over voldoende probleemoplossend vermogen. Maar liefst $70 \%$ van de bedrijven geeft dit aan, terwijl slechts $4 \%$ het belang van deze vaardigheid ziet afnemen. Ook het belang van de vaktechnische vaardigheden en het werken met IT is toegenomen. Daarnaast zijn communicatieve vaardigheden, het werken in een teamverband, maar ook het zelfstandig kunnen werken het afgelopen jaar steeds belangrijker geworden voor het technisch personeel in de Metalektro. Er wordt dus steeds meer gevraagd van de technici in de Metalektro. De meeste 
bedrijven vinden echter dat het belang van leidinggeven en commerciële vaardigheden niet gegroeid is. Bijna één op de tien bedrijven geeft zelfs aan dat commerciële vaardigheden het afgelopen jaar minder belangrijk geworden zijn. Dit zou erop kunnen wijzen dat verkoop en acquisitie steeds meer op het terrein van gespecialiseerde, niet-technische werknemers komt te liggen.

\section{Figuur 6.3}

Verandering in het belang van kennis en vaardigheden voor het goed functioneren van technische werknemers

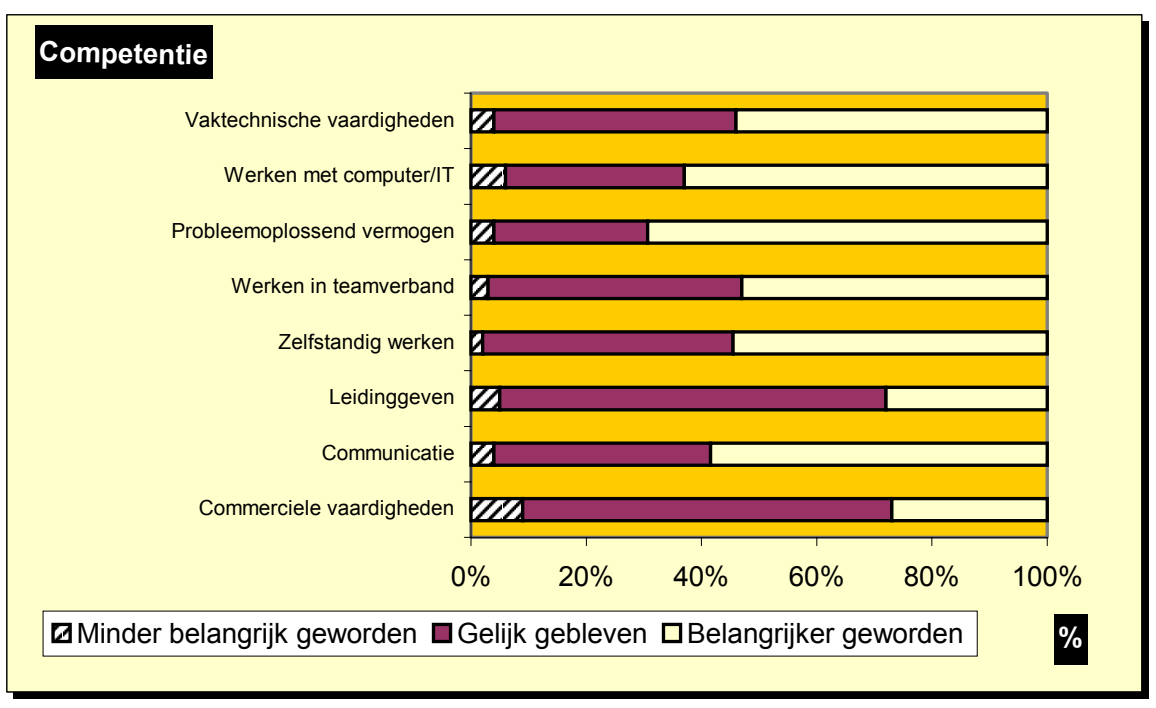

Bron: ROA/Werkgeverspanel Metalektro 2002

Zoals we net zagen is het voor het goed functioneren van het technisch personeel met name belangrijker geworden over voldoende 'probleemoplossend vermogen' te beschikken. Bedrijven in de machine-industrie melden echter beduidend minder vaak een toenemend belang van deze competentie. Verder vinden bedrijven in de sector metaalproducten vaker dat het 'werken in teamverband' in 2002 belangrijker geworden is. Opvallend is verder dat in middelgrote bedrijven (tussen de 100 en 250 medewerkers) het leidinggeven belangrijker geworden is voor het goed functioneren van technische medewerkers. Ook zijn er enkele regionale verschillen te ontdekken. Bedrijven in de regio Rijndelta geven vaker aan dat vaktechnische vaardigheden belangrijker geworden zijn dan bedrijven in de rest van Nederland. Bedrijven in de regio's Zuidoost en Noord noemen daarentegen vaker het werken in teamverband en bedrijven in het Oosten van het land het zelfstandig werken als competenties die belangrijker geworden zijn voor het goed functioneren van het technisch personeel. Bedrijven in het Westen van het land vinden echter vaker dat het belang van deze drie competenties juist is afgenomen.

Wat zijn de belangrijkste oorzaken van het belangrijker worden van bepaalde competenties voor het goed functioneren van het technisch personeel? Tabel 6.3 laat zien dat het leggen van meer verantwoordelijkheden op een lager niveau in de 
organisatie het meest als oorzaak voor de upgrading van de kwalificatie-eisen genoemd wordt $(74 \%)$. Ook de toenemende automatisering $(71 \%)$ en de invoering van nieuwe productietechnieken (43\%) zijn vaak een oorzaak van het upgradingsproces. Daarnaast valt op dat maar liefst $60 \%$ van de bedrijven het steeds allrounder worden van technische functies als oorzaak ziet voor de veranderingen in de vereiste kennis en vaardigheden.

Tabel 6.3

Belangrijkste oorzaken van het belangrijker worden van competenties voor het goed functioneren van technische werknemers*

Meer verantwoordelijkheden op een lager niveau in de organisatie

Toenemende automatisering

Nieuwe productietechniek

Technische functies worden steeds meer all-round

Technische functies worden steeds specialistischer Anders

${ }^{*}$ De verschillende percentages staan los van elkaar en hoeven dus niet op te tellen tot $100 \%$. Bron: ROA/Werkgeverspanel Metalektro 2002

Grote bedrijven noemen overwegend dezelfde oorzaken voor het belangrijker worden van competenties dan kleine bedrijven. Wel zijn er duidelijke verschillen tussen bedrijven uit de verschillende sectoren binnen de Metalektro. Zo noemen bedrijven in de sector metaalproducten vaker het specialistischer worden van technische functies (41\%). Daarnaast zijn er enkele regionale verschillen: bedrijven in de regio Zuidoost leggen de oorzaak voor het belangrijker worden van bepaalde competenties vaker bij een nieuwe productietechniek, terwijl bedrijven in de regio's Oost en Noord dit juist veel minder vaak noemen.

Het zal geen verbazing wekken dat bedrijven die vinden dat het werken met de computer belangrijker geworden is voor het goed functioneren van het technisch personeel, de toenemende automatisering als oorzaak hiervan zien. Het belangrijker worden van het werken in teamverband blijkt samen te hangen met het leggen van meer verantwoordelijkheden op een lager niveau in de organisatie. Een zelfde samenhang is er tussen het belangrijker worden van leidinggeven en het meer allround worden van technische functies en tussen het belangrijker worden van communicatieve vaardigheden en het invoeren van een nieuwe productietechniek. Ten slotte blijkt het belangrijker worden van commerciële vaardigheden vaker veroorzaakt te worden door het steeds specialistischer worden van technische functies.

\section{Inspelen op het veranderend belang van competenties}

Om op deze veranderingen in de vereiste kennis en vaardigheden in te spelen, staan bedrijven twee opties ter beschikking in de vorm van een 'make or buy' beslissing. In de eerste plaats kunnen bedrijven aan hun werknemers scholing aanbieden om hen van meer kennis en vaardigheden te voorzien. Dit wordt wel de trainingsoptie 
genoemd. Daarnaast kunnen bedrijven ook nieuw technisch personeel aannemen dat wel over de gevraagde competenties beschikt. Dit is de recruitment-optie. ${ }^{10}$

Tabel 6.4 laat zien dat $45 \%$ van de bedrijven de recruitment-optie volgt. Veel vaker wordt er door bedrijven in de Metalektro voor de trainingsoptie gekozen: negen op de tien bedrijven leidt het technisch personeel op de werkplek op, en driekwart biedt hen cursussen aan. Overigens treft slechts $3 \%$ van de bedrijven helemaal geen maatregelen om in te spelen op de veranderingen in de vereiste kennis en vaardigheden voor het technisch personeel.

Tabel 6.4

Manieren waarop bedrijven inspelen op het belangrijker worden van competenties voor technische werknemers*

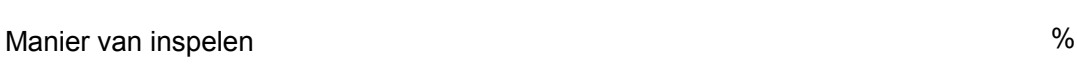

Nieuw, gekwalificeerd personeel aannemen $\quad 45$

Personeel op de werkplek opleiden $\quad 90$

Personeel cursussen aanbieden $\quad 76$

$\begin{array}{lr}\text { Anders } & 2 \\ \text { Geen speciale maatregelen } & 3\end{array}$

* De verschillende percentages staan los van elkaar en hoeven dus niet op te tellen tot $100 \%$.

Bron: ROA/Werkgeverspanel Metalektro 2002

Opvallend is dat bedrijven met 100 tot 250 werknemers veel vaker kiezen voor het werven van nieuw, gekwalificeerd personeel dan kleinere en grotere bedrijven. Bedrijven die metaalproducten maken spelen wat vaker op de veranderingen in door hun technisch personeel op de werkplek op te leiden. Het aanbieden van cursussen aan het personeel komt vaker voor bij bedrijven in de regio Rijndelta. Wellicht hangt dit samen met het feit dat bedrijven in de Rijndelta wat moeilijker aan technici kunnen komen. Uit hoofdstuk 3 bleek immers dat de bedrijven in deze regio in 2002 meer vacatures voor technisch personeel hadden openstaan dan bedrijven in de rest van Nederland. Dit maakt de recruitment-optie voor deze bedrijven minder aantrekkelijk. Bedrijven in de regio Noord daarentegen zien het aanbieden van cursussen minder vaak als de manier waarop zij op veranderingen in de vereiste competenties inspelen.

\subsection{Participatie in cursussen}

Zoals gezegd is het aanbieden van cursussen aan technische werknemers wijd verspreid binnen de Metalektro. Uit figuur 6.4 blijkt dat ruim $44 \%$ van de bedrijven het voor een optimaal productieproces ook zeer nodig vindt om het technisch personeel bij- of om te scholen. Daarnaast geeft de helft van de bedrijven aan dit enigszins nodig te vinden. Hierbij zijn geen significante verschillen gevonden tussen grote en kleine bedrijven of tussen bedrijven uit de verschillende sectoren. Evenmin zijn er

10. M. van Smoorenburg en A. de Grip (1997), De scholingsinspanning van bedrijven: trainen of werven, Economisch Statistische Berichten, 82: 848-849. 
regionale verschillen. De behoefte aan om- of bijscholing is het grootst bij bedrijven waar het competentieniveau van het technisch personeel tekortschiet. Met name in bedrijven waar technici onvoldoende of matig scoren op de competenties 'werken in teamverband' en 'probleemoplossend vermogen' wordt om- of bijscholing zeer gewenst gevonden.

\section{Figuur 6.4}

Behoefte aan om- of bijscholen van technische werknemers voor een optimaal productieproces

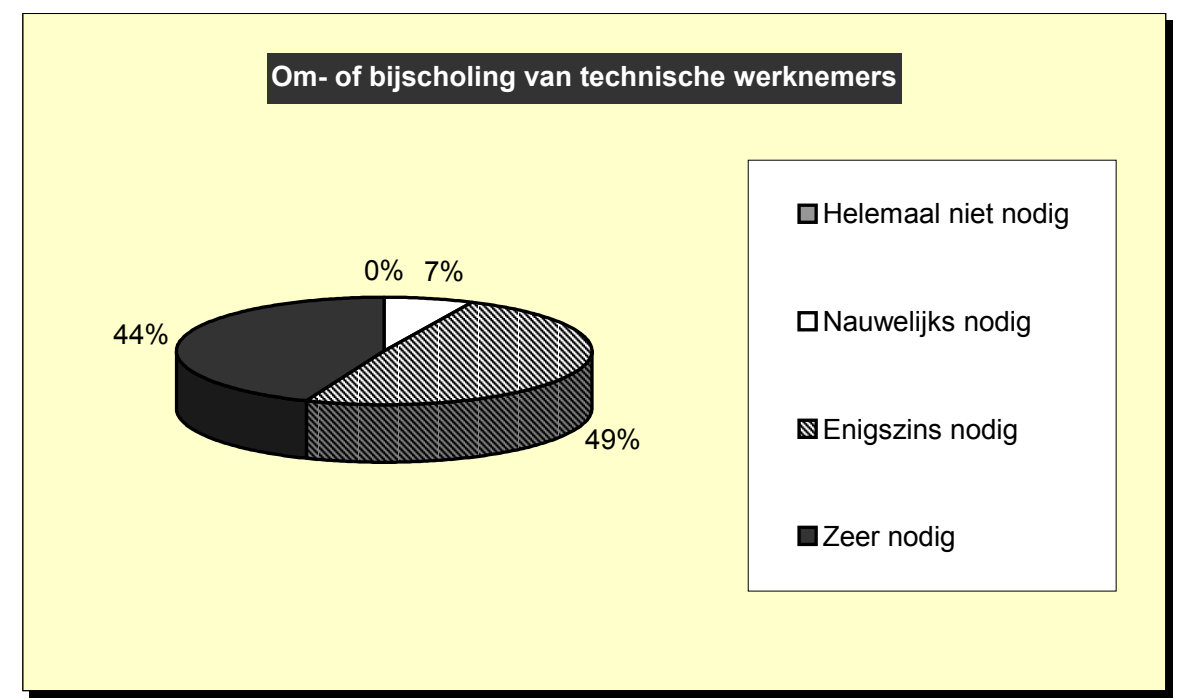

Bron: ROA/Werkgeverspanel Metalektro 2002

Overigens geeft bijna driekwart van de bedrijven in de Metalektro aan dat ze bij deze bij- en omscholing ondersteuning nodig hebben, met name in de vorm van het beschikbaar zijn van goede externe opleidingen en didactische ondersteuning bij interne cursussen. De behoefte aan ondersteuning is niet afhankelijk van bedrijfsgrootte of sector. Wel blijken bedrijven in de regio Oost wat minder behoefte aan ondersteuning bij om- of bijscholing te hebben dan bedrijven in de rest van Nederland.

\section{Cursusparticipatie}

In verreweg de meeste bedrijven in de Metalektro volgen technische werknemers ook daadwerkelijk cursussen. Zo laat tabel 6.5 zien dat technici in iets meer dan driekwart van de bedrijven in 2002 aan cursussen deelnamen die door het eigen bedrijf of bedrijfsvestiging georganiseerd werden. Daarnaast volgde in bijna negen op de tien bedrijven het technisch personeel externe cursussen. De tabel laat verder zien dat er duidelijke sectorverschillen in cursusparticipatie zijn. In de machineindustrie zijn er beduidend minder bedrijven waar technische werknemers cursussen volgen dan in de overige sectoren. Het percentage grote bedrijven waar werknemers aan interne cursussen deelnemen is gelijk aan het percentage kleine bedrijven. Wel is het zo dat met name de middelgrote (100 tot 250 werknemers) en grote bedrijven 
(meer dan 250 werknemers) hun technici aan externe cursussen laten deelnemen. Regionale verschillen in cursusparticipatie zijn niet gevonden. Opmerkelijk is verder dat bedrijven die aangeven dat vaktechnische vaardigheden en probleemoplossend vermogen belangrijker zijn geworden voor het goed functioneren van het technisch personeel, meer aan interne cursusparticipatie doen. Blijkbaar proberen bedrijven op deze wijze het niveau van technici in deze competenties te verhogen.

Tabel 6.5

Bedrijven met cursusparticipatie van technische werknemers in 2002, naar bedrijfssector

\begin{tabular}{lcccc}
\hline & $\begin{array}{c}\text { Metaalproducten } \\
\%\end{array}$ & $\begin{array}{c}\text { Machine-industrie } \\
\%\end{array}$ & $\begin{array}{c}\text { Overige sectoren } \\
\%\end{array}$ & $\begin{array}{c}\text { Totaal } \\
\%\end{array}$ \\
\hline Interne cursussen & 79 & 57 & 90 & 76 \\
Externe cursussen & 86 & 85 & 94 & 89 \\
\hline Bron: ROAMNerkgeverspanel Metalektro 2002 & & &
\end{tabular}

In de Metalektro volgden in 2002 ruim 27.000 technische werknemers een interne cursus. Dit betekent dat er gemiddeld genomen zo'n 13 technici per 100 werknemers aan een dergelijke cursus deelnamen. Nog eens bijna 29.500 technici participeerden in een externe cursus. Dit is circa $14 \%$ van de werknemers in een bedrijf. Deze cijfers zijn niet zonder meer vergelijkbaar met cijfers uit andere sectoren. In de eerste plaats betreft het hier de cursusparticipatie van technici, terwijl in de meeste cijfers over scholingsinspanningen alle werknemers in een bedrijf meegeteld worden. Daarnaast hebben de hier gepresenteerde cijfers betrekking op het gehele jaar 2002 en niet op een momentopname of een langere periode. In het rapport 'Werkgelegenheid en scholing 2001' wordt de scholingsparticipatie in de verschillende bedrijfssectoren vergeleken. ${ }^{11}$ Daarbij gaat het om de trainingsparticipatie op het moment van de enquête in 2000. Het blijkt dat $7 \%$ van de werkenden in de Metalektro op het moment van enquête een opleiding volgt. De sector chemie scoort wat hoger met een trainingsparticipatie van $9 \%$, maar de overige industrie (zoals textiel, hout- en bouwmaterialen, papier en de grafische industrie) weer wat lager met $4 \%$.

Welke cursussen worden er nu gevolgd door technische werknemers in de Metalektro? Figuur 6.5 laat zien dat cursussen op het gebied van vaktechnische vaardigheden het meest populair zijn. In maar liefst $86 \%$ van de bedrijven worden dergelijke cursussen door het technisch personeel intern gevolgd. Aan externe cursussen op dit gebied wordt zelfs in $90 \%$ van de bedrijven deelgenomen. Daarnaast worden er veel IT-cursussen gevolgd. In het algemeen blijkt dat er meer cursussen extern dan intern gevolgd worden. Zo volgen technici in 53\% van de bedrijven externe cursussen gericht op leiding geven, terwijl dergelijke cursussen in slechts $25 \%$ van de bedrijven intern gevolgd worden. Alleen bij cursussen op het gebied van 'werken in teamverband' en 'zelfstandig werken', is de verhouding andersom: hierbij wordt vaker aan interne cursussen deelgenomen.

11. ROA (2002), Werkgelegenheid en scholing 2001, ROA-R-2002/7, Maastricht. 
Figuur 6.5

Interne en externe cursusparticipatie van technische werknemers

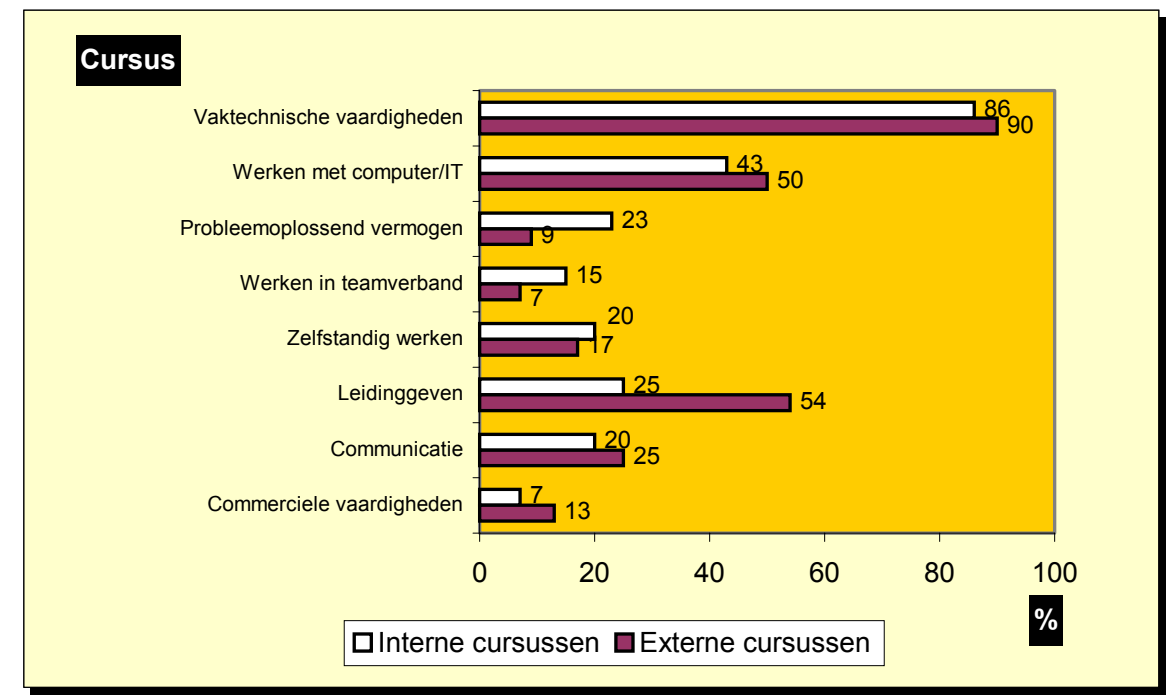

Bron: ROA/werkgeverspanel Metalektro 2002

Tabel 6.6 laat zien dat het volgen van een bepaalde cursus vaker voorkomt bij bedrijven die aangeven dat de competentie waar deze cursus zich op richt in 2002 belangrijker geworden is. De verschillen zijn met name groot bij de interne cursussen. Dit wijst erop dat er vooral geïnvesteerd wordt in competenties die steeds belangrijker worden voor het goed functioneren van technische werknemers.

Tabel 6.6

Interne en externe cursusparticipatie van technische werknemers, naar belangrijker worden van competenties in $2002^{*}$

\begin{tabular}{lcccc}
\hline Competentie & \multicolumn{2}{c}{ Interne cursussen } & \multicolumn{2}{c}{ Externe cursussen } \\
& $\begin{array}{c}\text { Competentie } \\
\text { wordt } \\
\text { belangrijker } \\
\%\end{array}$ & $\begin{array}{c}\text { Competentie } \\
\text { wordt niet } \\
\text { belangrijker } \\
\%\end{array}$ & $\begin{array}{c}\text { Competentie } \\
\text { wordt } \\
\text { belangrijker } \\
\%\end{array}$ & $\begin{array}{c}\text { Competentie } \\
\text { wordt niet } \\
\text { belangrijker } \\
\%\end{array}$ \\
\hline Vaktechnische vaardigheden & $92 \sim$ & 76 & 88 & 92 \\
Werken met computer / IT & 48 & 34 & $59 \sim$ & 32 \\
Probleemoplossend vermogen & $34 \sim$ & 9 & 13 & 7 \\
Werken in teamverband & $21 \sim$ & 7 & 7 & 14 \\
Zelfstandig werken & 23 & 11 & 57 & 53 \\
Leidinggeven & $48 \sim$ & 15 & 28 & 20 \\
Communicatie & $28 \sim$ & 9 & $22 \sim$ & 9 \\
Commerciële vaardigheden & $19 \sim$ & 3 & & 5 \\
\end{tabular}

significant verschil tussen bedrijven waarin de competentie belangrijker wordt en bedrijven waarin de competentie minder belangrijk wordt.

* De verschillende percentages staan los van elkaar en hoeven dus niet op te tellen tot $100 \%$.

Bron: ROA/Werkgeverspanel Metalektro 2002 
Ten slotte blijkt dat in middelgrote bedrijven (100 tot 250 werknemers) vaker cursussen op het gebied van leidinggeven gevolgd worden. Ook volgen technische werknemers in deze bedrijven vaker een externe IT-cursus. Sectorverschillen zijn er alleen bij de externe cursusparticipatie van het technisch personeel. Zo worden er in bedrijven in de sector metaalproduct meer vaktechnische cursussen gevolgd, terwijl bedrijven in de machine-industrie hun technici veel minder vaak aan cursussen op het gebied van leidinggeven laten deelnemen.

\section{Belemmerende factoren bij cursusparticipatie}

Ook al worden er door technische werknemers in de Metalektro heel wat cursussen gevolgd, toch komt tweederde van de bedrijven belemmerende factoren tegen wanneer het om de cursusparticipatie van het technisch personeel gaat. Figuur 6.6 laat zien dat $35 \%$ van de bedrijven aangeeft dat het technisch personeel niet gemist kan worden voor cursussen, terwijl $28 \%$ vindt dat de cursussen op een ongunstig moment plaatsvinden, of teveel geld kosten. $14 \%$ van de bedrijven geeft aan dat het technisch personeel niet geïnteresseerd is in het volgen van een cursus. Andere belemmeringen die genoemd worden zijn dat cursussen niet in de regio aangeboden worden (12\%), dat de kwaliteit van de aangeboden cursussen te laag is (10\%) en dat het technisch personeel dat cursussen volgt naar andere bedrijven vertrekt (5\%).

Figuur 6.6

Belemmerende factoren bij de cursusparticipatie van technische werknemers

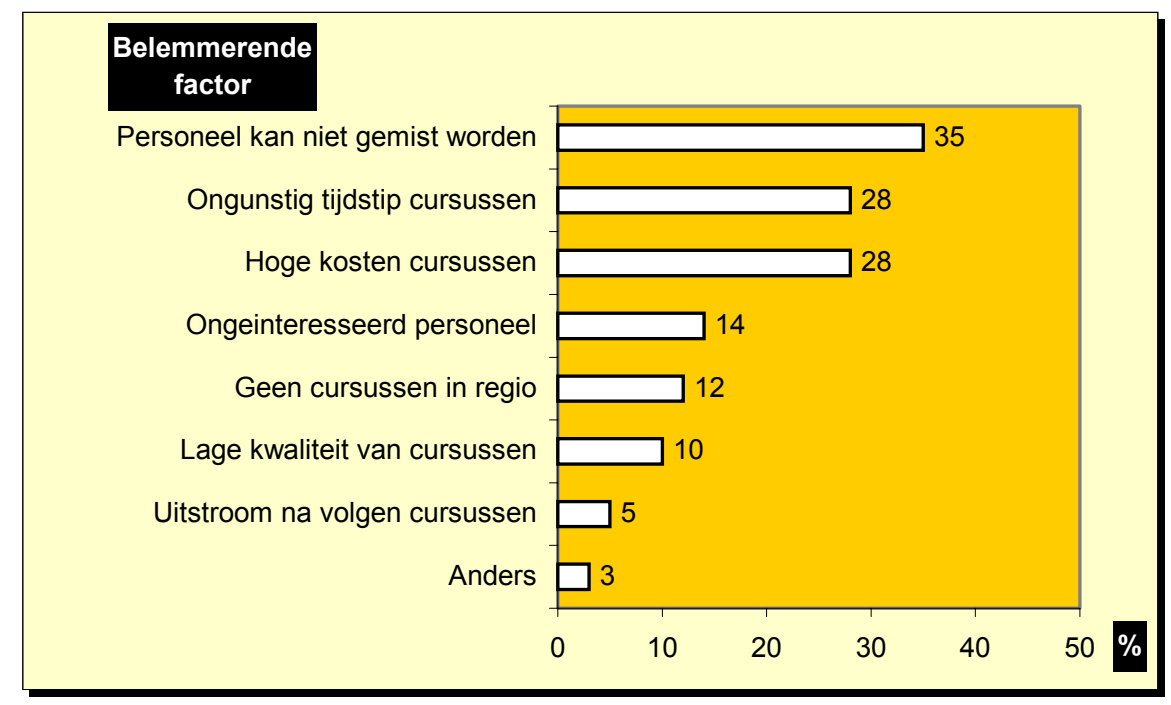

Bron: ROA/werkgeverspanel 2002

Grote en kleine bedrijven noemen dezelfde belemmerende factoren bij de cursusparticipatie van hun technische personeel. Bedrijven in de sector metaalproduct vinden beduidend vaker dat cursussen op ongunstige tijdstippen plaatsvinden. Dit blijkt overigens niet samen te hangen met het werken met ploegendiensten. Verder zijn er ook regionale verschillen te ontdekken. Bedrijven in het Zuiden van Nederland geven wat vaker aan dat de gewenste cursussen niet beschikbaar zijn in hun regio. 
Daarnaast vinden zij, evenals bedrijven in de regio Rijndelta, dat de kwaliteit van de aangeboden cursussen te laag is.

Ten slotte valt op dat in bedrijven die met één of meer belemmerende factoren bij cursusparticipatie te maken hebben het technisch personeel evenveel aan interne of externe cursussen deelneemt als in bedrijven die geen belemmeringen kennen. Dit zou erop kunnen wijzen dat de belemmerende factoren (nog) niet zo zwaarwegend zijn dat ze ook daadwerkelijk gevolgen hebben voor de cursusparticipatie van technische werknemers in de Metalektro. Een andere mogelijkheid is dat juist de bedrijven die meer willen investeren in de upgrading van de competenties van hun technisch personeel met belemmerende factoren geconfronteerd worden. 



\section{$7 \quad$ HRM-beleid en employability}

\subsection{Inleiding}

De veranderingen in de productietechnologie en de organisatie van veel bedrijven hebben ertoe geleid dat de werkenden in de Metalektro in toenemende mate nieuwe kennis verwerven om voldoende productief te blijven in de banen waarin ze werkzaam zijn. De toenemende aandacht voor het menselijk kapitaal als sleutelfactor in het productieproces uit zich enerzijds in een groeiende belangstelling voor het Human Resource Management (HRM). Anderzijds zijn werkenden steeds meer zelf verantwoordelijk voor hun ontwikkeling en hun eigen loopbaan. De toegenomen behoefte aan flexibiliteit in bedrijven maakt dit ook noodzakelijk. Het begrip employability is een concept dat de gevraagde flexibiliteit in het werk en de verantwoordelijkheid voor de eigen loopbaan integreert.

In dit hoofdstuk staat het HRM-beleid van bedrijven en de employability van de werknemers in de Metalektro centraal. In paragraaf 7.2 wordt ingegaan op enkele algemene gegevens over het HRM-beleid in Metalektrobedrijven en HRMkwaliteitskeurmerken. Vervolgens wordt in paragraaf 7.3 de aandacht gericht op de HRM-instrumenten die bedrijven in de Metalektro gebruiken. Tenslotte wordt er in paragraaf 7.4 gekeken naar de relatie tussen het HRM-beleid en de mate waarin werknemers deelnemen aan cursussen.

\subsection{Algemeen beeld van het HRM-beleid in de Metalektro}

Een belangrijke vraag met betrekking tot het HRM-beleid van een bedrijf is de vraag in hoeverre het HRM-beleid een centrale rol speelt in de organisatie. Tabel 7.1 geeft een overzicht van twee belangrijke kerngegevens op dit punt.

Tabel 7.1

Enkele kerngegevens van het HRM-beleid in de Metalektro, vierde kwartaal 2002*

\begin{tabular}{|c|c|}
\hline & $\%$ \\
\hline $\begin{array}{l}\text { HRM-beleid maakt deel uit van het strategisch beleid } \\
\text { Middellange termijn HRM-beleidsdoelen geformuleerd }\end{array}$ & $\begin{array}{l}82 \\
68\end{array}$ \\
\hline \multicolumn{2}{|c|}{$\begin{array}{l}\text { * De verschillende percentages staan los van elkaar en hoeven dus niet op te tellen tot } 100 \% \text {. } \\
\text { Bron: ROA/Werkgeverspanel Metalektro } 2002\end{array}$} \\
\hline \multicolumn{2}{|c|}{$\begin{array}{l}\text { Ruim } 80 \% \text { van de bedrijven in de Metalektro geeft aan dat het HRM-beleid deel uit } \\
\text { maakt van het strategisch beleid van de onderneming. Dat houdt in dat in het } \\
\text { overgrote deel van de Metalektro-bedrijven de waarde van het personeel voor de } \\
\text { onderneming in de bedrijfsstrategie wordt erkend. Bijna } 70 \% \text { van de bedrijven geeft } \\
\text { aan dat er middellange termijn HRM-bedrijfsdoelen worden geformuleerd. Dit geeft } \\
\text { aan dat het personeelsbeleid in de meeste bedrijven niet als een ad hoc beleid } \\
\text { gezien wordt, maar gestuurd vanuit een meer fundamenteel perspectief. }\end{array}$} \\
\hline
\end{tabular}


Wanneer wordt gekeken naar de relatie tussen het HRM-beleid en de beleidstrategie, dan valt op dat bedrijven in de sector metaalproducten en in de machine-industrie veel vaker aangeven dat hun HRM-beleid deel uit maakt van het strategisch beleid, dan dat bij bedrijven in de andere sectoren in de Metalektro het geval is. Grote bedrijven geven vaker aan dat hun HRM-beleid een onderdeel is van hun strategisch beleid. Ook het formuleren van middellange termijn doelen met betrekking tot het HRM-beleid komt bij kleine bedrijven duidelijk minder voor dan bij middelgrote en grote bedrijven. Kleinere bedrijven blijven op deze punten derhalve duidelijk achter.

\section{HRM-kwaliteitskeurmerken}

Om het HRM-beleid te structureren of verder uit te bouwen, wordt er tegenwoordig vaak gebruik gemaakt van zogenaamde HRM-keurmerken. Dit zijn erkenningen voor de kwaliteit van het HRM-beleid die door certificerende instellingen worden toegekend wanneer een bedrijf aan bepaalde voorwaarden op het gebied van het HRM-beleid voldoet. Verschillende van deze keurmerken hebben overigens een wat breder karakter en omvatten in feite de algehele kwaliteit van het productieproces van het bedrijf. Bij deze bredere kwaliteitskeurmerken is doorgaans veel oog voor het bewaken van de kwaliteit van het handelen van het personeel, waardoor het kwaliteitskeurmerk feitelijk ook betrekking heeft op het gevoerde HRM-beleid. Tabel 7.2 geeft een overzicht van de mate waarin bedrijven uit de Metalektro zich laten certificeren en om welke keurmerken het dan gaat.

Tabel 7.2

Percentage bedrijven met HRM-kwaliteitskeurmerken

\begin{tabular}{lr}
\hline & $\%$ \\
\hline Bedrijven met een keurmerk & 53 \\
Bedrijven zonder keurmerk, maar in verwervingstraject & 5 \\
Bedrijven zonder keurmerk & 42 \\
Waarvan soort keurmerk (behaald of in verwervingstraject) & \\
INK & 2 \\
liP & 0 \\
BPV & 2 \\
ISO-2000 & 55 \\
Ander keurmerk & 12
\end{tabular}

Bron: ROA/Werkgeverspanel Metalektro 2002

lets meer dan de helft van de bedrijven heeft een kwaliteitskeurmerk verworven, terwijl rond de $5 \%$ daar mee bezig is. Het kenmerk dat het meest gebruikt wordt is het algemene keurmerk ISO-2000. Zoals te verwachten valt in verband met de kosten en de beschikbaarheid van faciliteiten komt ook certificering het meeste voor bij de middelgrote en grote bedrijven. Voor wat de soorten certificering betreft valt alleen op dat het INK certificaat vaker voorkomt bij middelgrote bedrijven. 


\subsection{HRM-beleidsinstrumenten en employability}

Bedrijven kunnen hun HRM-beleid op verschillende manieren vormgeven. Zo kan de nadruk bijvoorbeeld liggen op het continu opleiden van het personeel door het aanbieden van cursussen. Andere bedrijven streven ernaar om hun personeel op een meer informele wijze inzetbaar te houden door het stimuleren van functieroulatie of andere mechanismen die het ervaringsdomein van de werknemers vergroten.

\section{Gebruik van HRM-beleidsinstrumenten}

In deze paragraaf gaan we in op de instrumenten die Metalektro-bedrijven gebruiken in het kader van hun HRM-beleid. Tabel 7.3 geeft een overzicht van de mate waarin 12 HRM-beleidsinstrumenten in die bedrijven gebruikt worden.

De tabel laat zien dat in de meeste bedrijven aan alle medewerkers opleidingsfaciliteiten worden aangeboden en functioneringsgesprekken worden gevoerd. Ook hebben de meeste bedrijven een bedrijfsopleidingsplan (BOP), beoordelingsgesprekken en geregeld werkoverleg. Opmerkelijk is ook dat er nogal wat bedrijven zijn die reeds werken met een competentie- of vaardighedenmatrix en scholingsgesprekken voeren met (een deel van) het personeel. Voor zover bedrijven werken met functieroulatie heeft dit meestal slechts betrekking op een beperkt deel van het personeel. Ook zijn er vrijwel geen bedrijven met erkenning van verworven competenties (EVC) of een loopbaanadvies- of mobiliteitscentrum.

Tabel 7.3

Gebruik van HRM-instrumenten voor het technisch personeel

\begin{tabular}{lcccc}
\hline HRM-instrument & $\begin{array}{c}\text { Voor alle } \\
\text { werknemers } \\
\%\end{array}$ & $\begin{array}{c}\text { Voor een } \\
\text { meerder- } \\
\text { heid } \\
\%\end{array}$ & $\begin{array}{c}\text { Voor een } \\
\text { minder-heid } \\
\%\end{array}$ & $\begin{array}{c}\text { Niet } \\
\text { gebruikt }\end{array}$ \\
\hline Opleidingsfaciliteiten & 72 & 19 & 4 & 5 \\
Bedrijfsopleidingsplan (BOP) & 59 & 10 & 12 & 19 \\
Persoonlijk ontwikkelingsplan (POP) & 12 & 15 & 26 & 47 \\
Competentie- of vaardighedenmatrix & 22 & 16 & 9 & 53 \\
Erkenning Verworven Competenties (EVC) & 2 & 5 & 7 & 86 \\
Loopbaanontwikkeling & 3 & 5 & 49 & 43 \\
Functieroulatie & 7 & 18 & 34 & 41 \\
Functioneringsgesprekken & 68 & 12 & 10 & 10 \\
Beoordelingsgesprekken & 63 & 8 & 9 & 20 \\
Scholingsgesprekken & 29 & 16 & 30 & 25 \\
Geregeld werkoverleg & 61 & 30 & 5 & 5 \\
Loopbaanadvies- of mobiliteitscentrum & 1 & 0 & 9 & 91 \\
\hline Bron: ROA/WerkgeVerspanel Metalektro 2002 & & & 5 & \\
\hline
\end{tabular}

Bron: ROA/Werkgeverspanel Metalektro 2002

Uit achterliggende gegevens blijkt dat er een paar opvallende verschillen naar bedrijfssector en bedrijfsgrootte te constateren zijn. Zo werken bedrijven in de metaalproductensector minder vaak met persoonlijke ontwikkelingsplannen (POPs) dan bedrijven in de andere sectoren van de Metalektro. Bedrijven zonder opleidingsfaciliteiten zijn allemaal kleine bedrijven terwijl kleine bedrijven ook vaak niet over een bedrijfsopleidingsplan beschikken. Ook op het punt van persoonlijke ontwik- 
kelingsplannen (POPs), carrièreplanning en het houden van geregeld werkoverleg scoren de kleine bedrijven lager dan de middelgrote of grote bedrijven.

\section{HRM-beleidsinstrumenten en employability van de medewerkers}

Tabel 7.4 geeft een overzicht van de HRM-instrumenten waarvan bedrijven aangeven dat ze behoren tot de drie belangrijkste instrumenten om de employability van het technisch personeel te stimuleren. Het bieden van opleidingsfaciliteiten en het houden van functioneringsgesprekken en geregeld werkoverleg worden het vaakst genoemd als belangrijkste HRM-instrumenten. Door veel minder bedrijven wordt het hebben van een bedrijfsopleidingsplan (BOP), het houden van beoordelingsgesprekken en persoonlijke ontwikkelingsplannen (POP) als de belangrijkste HRMinstrumenten in het kader van de employability van hun personeel genoemd. Een minderheid van de bedrijven geeft aan dat functieroulatie, loopbaanontwikkeling, scholingsgesprekken, EVC of het hebben van een loopbaanadvies- of mobiliteitscentrum één van de belangrijkste HRM-instrumenten is.

Tabel 7.4

Belangrijkste HRM-instrumenten voor de employability van het technisch personeel ${ }^{\star}$

HRM-instrument

Opleidingsfaciliteiten

Functioneringsgesprekken

Geregeld werkoverleg

Bedrijfsopleidingsplan (BOP)

Beoordelingsgesprekken

Persoonlijk ontwikkelingsplan (POP)

Competentie- of vaardighedenmatrix

Functieroulatie

Loopbaanontwikkeling

Scholingsgesprekken

Anders

Erkenning Verworven Competenties (EVC)

Loopbaanadvies- of mobiliteitscentrum

* De verschillende percentages staan los van elkaar en hoeven dus niet op te tellen tot $100 \%$. Bron: ROA/Werkgeverspanel Metalektro 2002

Wanneer we kijken naar verschillen tussen sectoren binnen de Metalektro, dan valt op dat relatief veel bedrijven in de machine industrie de competentie- of vaardighedenmatrix één van de belangrijkste HRM-instrumenten vinden. In dezelfde sector worden daarentegen scholingsgesprekken heel weinig als belangrijk HRMinstrument gezien. Voor de meeste HRM-instrumenten neemt het belang toe naarmate de bedrijfsgrootte toeneemt. Hierop zijn echter enkele uitzonderingen. Zo wordt functieroulatie vooral binnen middelgrote bedrijven als belangrijk HRMinstrument gezien. Daarentegen worden functioneringsgesprekken vooral in kleine en middelgrote bedrijven als belangrijk ervaren, terwijl geregeld werkoverleg vooral in de kleinste bedrijven als een belangrijk HRM-instrument wordt gezien. 
Het HRM-beleid van bedrijven bestaat vaak uit combinaties van bepaalde, aan elkaar gerelateerde HRM-instrumenten. Om te bezien in welke mate het gebruik van bepaalde HRM-instrumenten samenhangt wordt in tabel 7.5 een overzicht van de correlaties tussen de verschillende instrumenten gepresenteerd. Significante correlaties van 0,4 of hoger worden aangegeven door de grijze vlakken in de tabel.

De tabel laat zien dat opleidingsfaciliteiten vaak onderdeel zijn van een HRM-beleid waarin ook bedrijfsopleidingsplannen en scholings- en beoordelingsgesprekken een plaats hebben. Twee andere HRM-instrumenten die geregeld samen voorkomen zijn het opstellen van persoonlijke ontwikkelingsplannen en het hebben van een competentie- of vaardighedenmatrix. Verder komen functioneringsgesprekken, scholingsgesprekken en geregeld werkoverleg relatief vaak in combinatie voor.

Tabel 7.5

Correlaties tussen HRM-instrumenten voor het technisch personeel

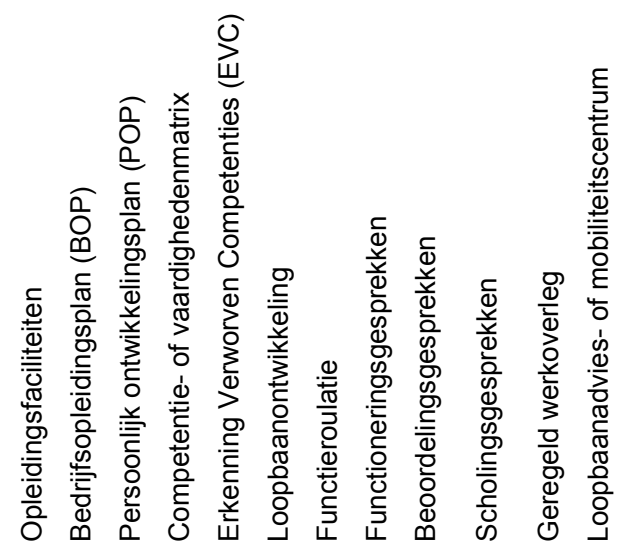

Opleidingsfaciliteiten

Bedrijfsopleidingsplan (BOP)

Persoonlijk ontwikkelingsplan (POP)

Competentie- of vaardighedenmatrix

Erkenning Verworven Competenties (EVC)

Loopbaanontwikkeling

Functieroulatie

Functioneringsgesprekken

Beoordelingsgesprekken

Scholingsgesprekken

Geregeld werkoverleg

Loopbaanadvies- of mobiliteits-centrum
1,0

$0,51,0$

$$
0,31,0
$$$$
0,30,4 \quad 1,0
$$$$
0,20,3 \quad 1,0
$$

$0,3 \quad 0,20,3 \quad 0,3 \quad 1,0$

$0,2 \quad 1,0$

$0,40,30,2 \quad 0,2 \quad 1,0$

$0,3 \quad 0,30,2 \quad 0,2 \quad 0,51,0$

$0,4 \quad 0,30,2 \quad 0,20,30,2 \quad 1,0$

$\begin{array}{lllllll}0,3 & 0,3 & 0,2 & 0,2 & 0,2 & 0,5 & 0,4\end{array}$

$\begin{array}{lllll}0,3 & 0,4 & 0,3 & 0,3 & 1,0\end{array}$

Bron: ROA/Werkgeverspanel Metalektro 2002 


\subsection{HRM-beleid en cursusdeelname}

In deze paragraaf wordt gekeken in hoeverre het HRM-beleid invloed heeft op de cursusparticipatie van de medewerkers. De cursusparticipatie wordt gemeten aan de hand van het gemiddelde aantal gevolgde cursussen dat een technisch medewerker in 2002 heeft gevolgd. Deze cursusparticipatie op bedrijfsniveau wordt verklaard aan de hand van het gebruik van HRM-instrumenten, de vraag of het niveau van de vaktechnische vaardigheden is toegenomen en enkele achtergrondvariabelen.

Tabel 7.6 geeft een overzicht van de relatie tussen het gevoerde HRM-beleid en de opleidingsparticipatie. Aangezien een aantal van de HRM-instrumenten in meer of mindere mate met elkaar correleren, is het moeilijk om vast te stellen wat het precieze effect is van de verschillende instrumenten. Daarom zijn alleen de HRMinstrumenten die er enigszins uit springen in de tabel opgenomen.

Tabel 7.6

HRM-beleid en cursusparticipatie technisch personeel

\begin{tabular}{lcrr}
\hline & $\begin{array}{r}\text { Effect } \\
\text { (teken) }\end{array}$ & $\begin{array}{r}\text { Effect } \\
\text { (getal) }\end{array}$ & p-waarde \\
\hline $\begin{array}{l}\text { Opleidingsfaciliteiten } \\
\text { Functieroulatie }\end{array}$ & + & 0,14 & 0,04 \\
Niveau vaktechnische vaardigheden toegenomen & - & $-0,23$ & 0,04 \\
Verklarende waarde $\left(\mathrm{R}^{2}\right)$ & & 0,19 & 0,00 \\
Aantal cases & & 0,16 & \\
& & 104 & \\
\hline
\end{tabular}

Bron: ROA/Werkgeverspanel Metalektro 2002

Als we kijken naar de effecten van HRM-instrumenten op cursusparticipatie dan zien we dat het bieden van opleidingsfaciliteiten het gemiddeld aantal cursussen per medewerker met 0,14 doet stijgen. Functieroulatie heeft daarentegen een negatief effect op de gemiddelde cursusparticipatie. Dit zou verklaard kunnen worden door het gegeven dat bedrijven waarin functieroulatie wordt toegepast dit doen als substituut voor het leren door middel van cursussen. Ten slotte neemt de cursusdeelname per medewerker met 0,19 cursus toe wanneer het niveau van de benodigde vaktechnische vaardigheden is toegenomen. Uit de analyses in hoofdstuk 6 bleek ook al dat er meer cursussen op een bepaald gebied gevolgd worden in bedrijven waar het niveau van deze competenties toeneemt.

Kort samengevat betekent dit de cursusdeelname gerelateerd is aan zowel het niveau van de benodigde vaardigheden als het gevoerde HRM-beleid. De uitkomsten tonen aan dat met name het bieden van opleidingsfaciliteiten een erg belangrijk instrument is om de cursusparticipatie te bevorderen. 


\section{Bijlage A Het werkgeverspanel}

In januari 2002 zijn alle Metalektrobedrijven, die aangesloten zijn bij de werkgeversorganisatie FME-CWM en vallen onder de CAO Metalektro, benaderd om deel te nemen aan het werkgeverspanel Metalektro. Van de 1.267 bedrijven reageerden er 345 positief. In de loop van 2002 heeft een aantal bedrijven zich afgemeld (paneluitval), maar zijn er ook enkele nieuwe bedrijven bijgekomen. Deze nieuwe deelnemers kregen naast de reguliere meting een speciale instapvragenlijst voorgelegd.

Aan een contactpersoon van deze bedrijven is ieder kwartaal een uitnodiging per email gestuurd om deel te nemen aan het werkgeverspanel. Zij konden dan via Internet een vragenlijst invullen. Het afnemen van vragenlijsten via Internet heeft verschillende voordelen. Niet alleen zijn de kosten in vergelijking met telefonische of schriftelijke enquêtering gering, de antwoorden worden ook niet door een interviewereffect vertekend. Respondenten kunnen de vragenlijsten in hun eigen tempo en op een moment dat hen het beste uitkomt invullen. Ten slotte maakt bevraging via Internet het mogelijk met enige regelmaat relatief korte vragenlijsten te verzenden, hetgeen de enquêtedruk verlicht en bovendien de betrokkenheid van de respondenten bij de monitor kan vergroten.

Om de respons te vergroten, krijgen alle deelnemers aan het werkgeverspanel Metalektro na afloop van iedere meting op korte termijn inzage in de resultaten van het panel waartegen ze hun eigen positie kunnen afzetten. Deze 'bedrijfsfoto' biedt de mogelijkheid de positie van het bedrijf te benchmarken ten opzichte van andere bedrijven in de sector. Ook is er telkens door de Stichting $\mathrm{A}+\mathrm{O}$ een nieuwsbrief uitgebracht, waarin de belangrijkste resultaten van de Arbeidsmarktmonitor Metalektro beschreven werden. Deze nieuwsbrieven werden, samen met een oproep om aan het panel deel te nemen, verzonden aan alle bedrijven in de Metalektro.

Naast de vier vragenlijsten is er in november 2002 ook een vragenlijst via Internet voorgelegd aan een lid van het management of directie. Voor deze meting werden naast de aan het werkgeverspanel deelnemende bedrijven opnieuw alle overige bedrijven in de Metalektro benaderd. Van de 197 bedrijven die aangaven mee te willen doen hebben er uiteindelijk 110 de vragenlijst van de managementmeting ingevuld.

Om na te gaan of de gegevens van deelnemende bedrijven (steekproef) representatief zijn voor alle bedrijven in de Metalektro (populatie), is gekeken naar de omvang, sector en regio van de bedrijven. Het blijkt dat de kleine bedrijven in de steekproef ondervertegenwoordigd en de grote bedrijven oververtegenwoordigd zijn. Verder blijken er relatief weinig bedrijven die metaalproducten maken aan meting 3 en 4 te hebben deelgenomen, en relatief veel bedrijven uit de sector elektrotechniek. Ook wat regio betreft zijn er enkele verschillen, maar deze zijn veel kleiner. Vanwege de verschillen tussen populatie en steekproef is er besloten het steekproefbestand te 
wegen naar bedrijfsomvang, bedrijfssector en regio. Deze techniek wordt in statistisch onderzoek veel gebruikt en zorgt ervoor dat de representativiteit van het werkgeverspanel bewaakt is.

Om vervolgens uitspraken te kunnen doen over bijvoorbeeld het totaal aantal vacatures dat in de Metalektro openstaat, is het aantal vacatures dat bij de deelnemende bedrijven openstaat opgehoogd. Deze ophoging van vacaturecijfers komt overeen met de procedure die het CBS volgt in hun vacature-enquête. Dit heeft als voordeel dat we de ontwikkeling kunnen schetsen van het totaal aantal vacatures in de Metalektro. Ook bij de cijfers over de in- en uitstroom van werknemers in de Metalektro is een ophoging tot totalen voor de hele sector toegepast. 


\section{Bijlage B Classificaties}

\section{B1: Bedrijfssectorclassificatie Metalektro}

\begin{tabular}{ll}
\hline Bedrijfssector & SBI '93* \\
\hline Basismetaal & $27000-27999$ \\
Metaalproducten & $28000-28999,36000-36099,36200-36599,36700-36999$ \\
Machine-industrie & $29000-29999$ \\
Elektrotechniek & $30000-33999$ \\
Transportmiddelen & $34000-35999$ \\
& \\
\hline CBS (1993), Standaard Bedrijfsindeling 1993, Voorburg/Heerlen.
\end{tabular}

B2: Belangrijkste beroepsgroepen in de Metalektro

\begin{tabular}{ll}
\hline ROA-beroepsgroep & SBC '92 \\
\hline & 106 \\
Productiemedewerkers & 108 \\
Laders en lossers & 264 \\
Metaalarbeiders & 265 \\
Assembleurs & 282 \\
Chauffeurs & 315 \\
Receptionisten en administratieve medewerkers & 462 \\
Installateurs & 464 \\
Bankwerkers en lassers & 465 \\
Monteurs & 467 \\
Elektromonteurs & 493 \\
Medisch laboranten & 513 \\
Productieplanners & 515 \\
Boekhouders en secretaresses & 516 \\
Commercieel medewerkers (MBO niveau) & 665 \\
Werktuigbouwkundig ontwerpers en hoofden technische dienst & 714 \\
Systeemanalisten & 716 \\
Commercieel medewerkers (HBO niveau) & \\
\end{tabular}

* CBS (1993), Standaard Beroepenclassificatie 1992, Voorburg/Heerlen. 
B3: Belangrijkste opleidingstypen in de Metalektro

\begin{tabular}{|c|c|}
\hline Opleidingstype & SOI ' $98^{*}$ \\
\hline Basisonderwijs & $\begin{array}{l}\text { 10111, 10121, 10123, 10128, 20112, 20121, 20123, } \\
20128,20180\end{array}$ \\
\hline VMBO theorie & $\begin{array}{l}30112,30114,30115,30116,30117,30121,30123 \\
30128,30131,30132,30133,30134,30135,30138 \\
30141,30142,30143,30144,30145,30146,30148 \\
30154,30155,30164,30174,30180\end{array}$ \\
\hline VMBO bouwtechniek & $33611,33613,33614,33615,33617,33618,33623,33625$ \\
\hline VMBO mechanische techniek & $33631,33633,33638$ \\
\hline VMBO elektrotechniek & $33651,33653,33654,33655$ \\
\hline VMBO (uiterlijke) verzorging & $\begin{array}{l}30667,30671,35118,35120,35148,35160,35180 \\
35210,35231,35235,35380,35430,37118,37120 \\
37143,37145,37150,37161,37163,37165,37188 \\
38110,38121,38123\end{array}$ \\
\hline HAVO/MWO & $\begin{array}{l}\text { 40151, 40152, 40153, 40154, 40155, 40158, 40161, } \\
40162,40163,40164,40165,40166,40168,40171 \\
40172,40173,40174,40175,40176,40178,40180\end{array}$ \\
\hline MBO bouw & $\begin{array}{l}43611,43613,43614,43615,43618,43811,43814 \\
43815,43818\end{array}$ \\
\hline $\begin{array}{l}\text { MBO werktuigbouw en } \\
\text { mechanische techniek }\end{array}$ & $\begin{array}{l}42210,43631,43633,43638,43643,43647,43648 \\
43833,43838,43843,43847,43848,44231,44250\end{array}$ \\
\hline MBO motorvoertuigentechniek & 43641,43841 \\
\hline MBO elektrotechniek & $43651,43652,43653,43654,43655,43851,43853$ \\
\hline MBO administratie & $\begin{array}{l}46110,46133,46138,46141,46148,46180,46611 \\
46613,46618,46621,46623,46628\end{array}$ \\
\hline MBO handel & $43617,43685,43817,43885,46143,46150,46280$ \\
\hline HBO werktuigbouwkunde & $\begin{array}{l}53631,53633,53635,53643,53645,53646,53648 \\
53841,53847,53848\end{array}$ \\
\hline HBO elektrotechniek & $\begin{array}{l}53110,53120,53130,53150,53170,53183,53188 \\
53651,53653,53654,53655,53682,53683\end{array}$ \\
\hline HBO bedrijfskunde & $52310,52380,56120,56220$ \\
\hline
\end{tabular}

${ }^{*}$ CBS (1998), Standaard Onderwijsindeling 1998, Voorburg/Heerlen. 